Prepared in cooperation with the Chester County Water Resources Authority and the Chester County Health Department

\title{
Groundwater-Quality Monitoring Program in Chester County, Pennsylvania, 1980-2008
}

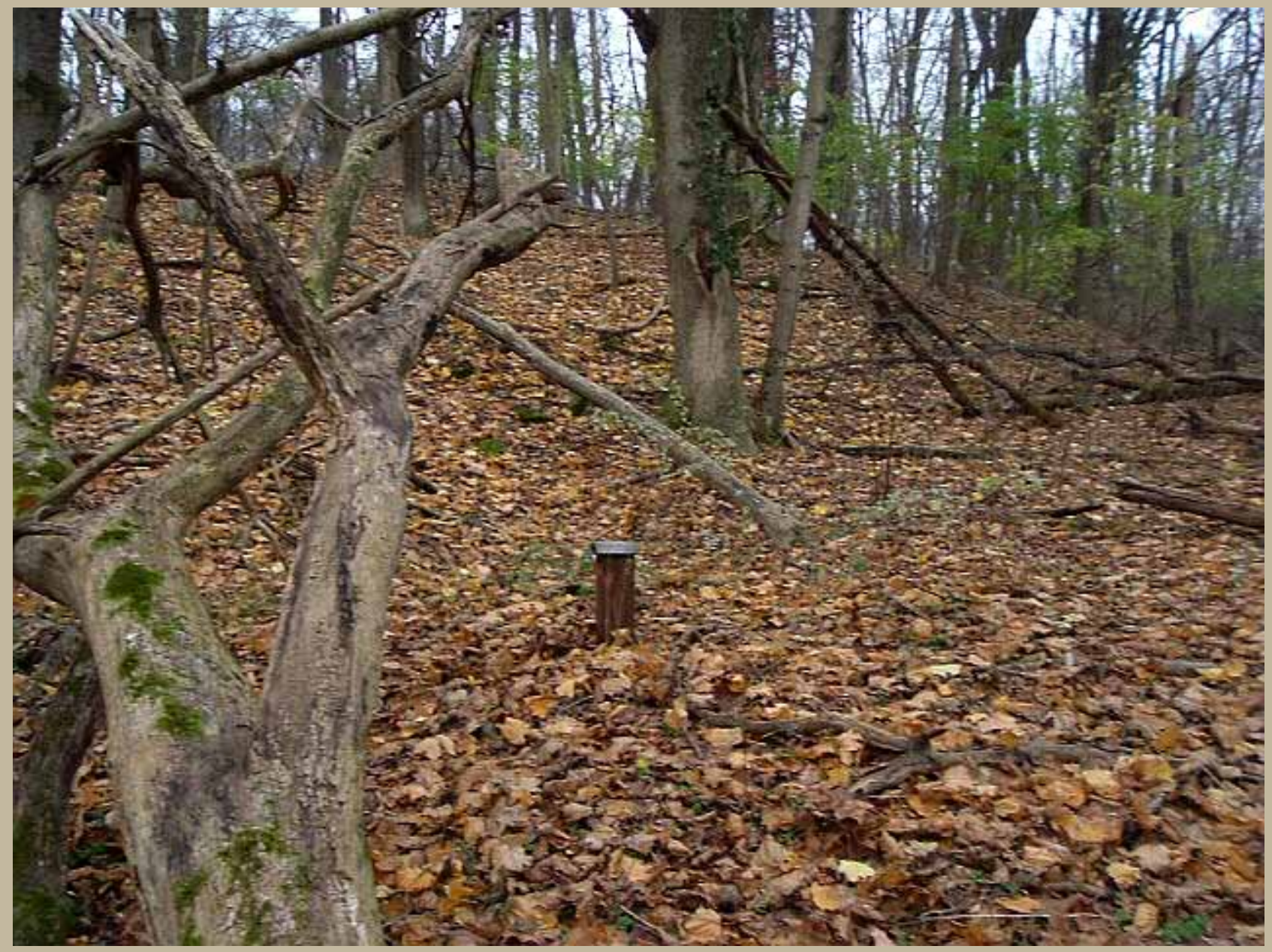

Scientific Investigations Report 2010-5087 
Front cover-Well CH-3289 in eastern Chester County, Pennsylvania, sampled by the U.S. Geological Survey in 1988 as part of the Chester County groundwater-quality monitoring program. (Photograph taken by Arthur Lilienthal, U.S. Geological Survey, Exton, Pennsylvania, 2009.) 


\section{Groundwater-Quality Monitoring Program in Chester County, Pennsylvania, 1980-2008}

By Lisa A. Senior and Ronald A. Sloto

Prepared in cooperation with the Chester County Water Resources Authority and the Chester County Health Department

Scientific Investigations Report 2010-5087 


\section{U.S. Department of the Interior \\ KEN SALAZAR, Secretary \\ U.S. Geological Survey \\ Marcia K. McNutt, Director}

U.S. Geological Survey, Reston, Virginia: 2010

For more information on the USGS - the Federal source for science about the Earth, its natural and living resources, natural hazards, and the environment, visit http://www.usgs.gov or call 1-888-ASK-USGS

For an overview of USGS information products, including maps, imagery, and publications, visit http://www.usgs.gov/pubprod

To order this and other USGS information products, visit http://store.usgs.gov

Any use of trade, product, or firm names is for descriptive purposes only and does not imply endorsement by the U.S. Government.

Although this report is in the public domain, permission must be secured from the individual copyright owners to reproduce any copyrighted materials contained within this report.

Suggested citation:

Senior, L.A., and Sloto, R.A., 2010, Groundwater-quality monitoring program in Chester County, Pennsylvania, 19802008: U.S. Geological Survey Scientific Investigations Report 2010-5087, 83 p. 


\section{Contents}

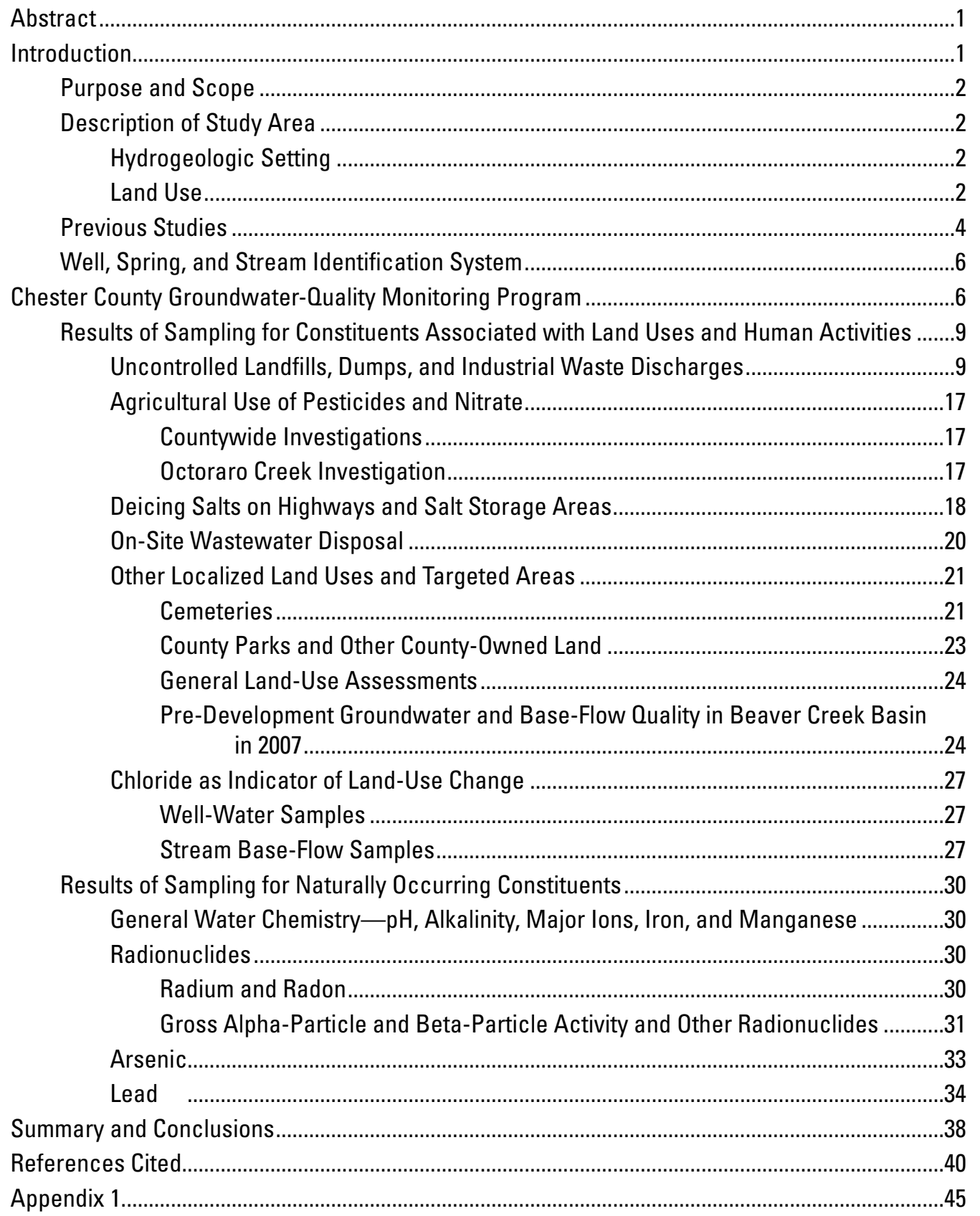




\section{Figures}

1. Map showing generalized geology of Chester County, $\mathrm{Pa}$

2. Map showing land use in 2000 in Chester County, $\mathrm{Pa}$., and location of selected parks and other county-owned land

3. Map showing National Priority List (Superfund) and Resource Conservation and Recovery Act (RCRA) sites in Chester County, Pa., and locations of wells sampled through the Chester County groundwater-quality monitoring program that had detections of volatile organic compounds.

4. Map showing location of base-flow samples collected as part of the Chester County groundwater-quality monitoring program and selected other areas of base-flow sampling, 1966 through 2008, Chester County, Pa

5. Map showing nitrate concentrations in base-flow samples from 7 tributaries to Octoraro Creek and in groundwater samples from 21 wells in those tributary basins, Chester County, Pa., 2000.

6. Graphs showing chloride concentrations in base flow sampled annually in autumn at USGS streamgages: $(A) 01479800$ East Branch Red Clay Creek near Five Points, Pa., 1970-2007; (B) 01480653 East Branch Brandywine Creek near Glenmoore, Pa., 1969-2007; (C) 01472157 French Creek near Phoenixville, Pa., 1969-2007; (D) 01472080 Pigeon Creek near Slonaker, Pa., 1969-2007; and (E) 01472190 Pickering Creek near Phoenixville, Pa., 1967-2007

7. Graphs showing radium-224 activities in relation to $(A)$ gross alpha-particle activities and $(B)$ radium-228 activities in samples from 14 wells in 9 different geologic units, Chester County, Pa., 1999.

8. Graphs showing relation between 72-hour gross alpha-particle activities and 30-day gross alpha-particle activities in groundwater samples from 18 wells in the Chickies Quartzite or Antietam and Harpers Formation, undivided, Chester County, Pa., 2003.

9. Graphs showing relation between 30-day gross alpha-particle activities and pH in groundwater samples from 18 wells in the Chickies Quartzite or Antietam and Harpers Formation, undivided, Chester County, Pa., 2003

10. Graph showing relation between concentrations of dissolved and total lead and $\mathrm{pH}$ in groundwater samples from 17 wells in the Chickies Quartzite or Antietam and Harpers Formation, undivided, Chester County, Pa., 2003

11. Graph showing relation between lead-210 activities and radon-222 activities in groundwater samples from 17 wells in the Chickies Quartzite or Antietam and Harpers Formation, undivided, Chester County, Pa., 2003

12. Graph showing relation between $\mathrm{pH}$ and the ratio of dissolved to total lead concentrations in groundwater samples from 17 wells in the Chickies Quartzite or Antietam and Harpers Formation, undivided, Chester County, Pa., 2003. 


\section{Tables}

1. Contaminants or constituents of concern in groundwater that are commonly associated with various land uses for the Chester County groundwater-quality monitoring program, 1980-2008.

2. Number and type of sites sampled and reason for sample collection listed by possible contaminant source for the Chester County groundwater-monitoring program, 1980-2008.

3. Maximum contaminant levels, health advisories, and secondary maximum contaminant levels established by the U.S. Environmental Protection Agency for selected constituents in drinking water.

4. Concentrations of volatile organic compounds detected in wells sampled more than once, Chester County, Pa.

5. Concentrations of chloride, boron, nitrate, and orthophosphate detected in samples from nine wells in residential areas with on-site wastewater disposal in use since the 1970s, Chester County, $\mathrm{Pa}$

6. Concentrations of nitrate, orthophosphate, chloride, boron, and organic wastewater compounds detected in samples from five wells and five streams in headwater areas that have residential land use with on-site wastewater disposal, Chester County, Pa., 2008

7. Concentrations of formaldehyde and lead and $\mathrm{pH}$ detected in samples from 10 wells near cemeteries, Chester County, Pa., 1990 through 1997.

8. Concentrations of nitrate, chloride, boron, and organic wastewater compounds detected in nine base-flow samples and two well-water samples near Beaver Creek Reservoir and in base-flow samples at five other stream sites collected in 2007 as part of the Chester County groundwater-quality monitoring program, Chester County, $\mathrm{Pa}$. 


\section{Conversion Factors and Abbreviations}

\begin{tabular}{lcl}
\hline \multicolumn{1}{c}{ Multiply } & \multicolumn{1}{c}{ By } & \multicolumn{1}{c}{ To obtain } \\
\hline inch (in.) & \multicolumn{1}{c}{ Length } & \\
inch (in.) & 2.54 & centimeter $(\mathrm{cm})$ \\
foot (ft) & 25.4 & millimeter $(\mathrm{mm})$ \\
mile (mi) & 0.3048 & meter $(\mathrm{m})$ \\
\hline \multicolumn{2}{c}{ Area } & kilometer $(\mathrm{km})$ \\
\hline acre & 1.609 & \\
acre & $4,047 \quad 0.4047$ & square meter $\left(\mathrm{m}^{2}\right)$ \\
acre & 0.4047 & hectare $($ ha) \\
acre & 0.004047 & square hectometer $\left(\mathrm{hm}^{2}\right)$ \\
square mile $\left(\mathrm{mi}^{2}\right)$ & 259.0 & square kilometer $\left(\mathrm{km}^{2}\right)$ \\
square mile $\left(\mathrm{mi}^{2}\right)$ & 2.590 & hectare $($ ha) \\
\hline \multicolumn{2}{c}{ Radioactivity } & square kilometer $\left(\mathrm{km}^{2}\right)$ \\
\hline picocurie per liter $(\mathrm{pCi} / \mathrm{L})$ & 0.037 & becquerel per liter $(\mathrm{Bq} / \mathrm{L})$ \\
\hline
\end{tabular}

Temperature in degrees Celsius $\left({ }^{\circ} \mathrm{C}\right)$ may be converted to degrees Fahrenheit $\left({ }^{\circ} \mathrm{F}\right)$ as follows:

${ }^{\circ} \mathrm{F}=\left(1.8 x^{\circ} \mathrm{C}\right)+32$

Temperature in degrees Fahrenheit $\left({ }^{\circ} \mathrm{F}\right)$ may be converted to degrees Celsius $\left({ }^{\circ} \mathrm{C}\right)$ as follows:

${ }^{\circ} \mathrm{C}=\left({ }^{\circ} \mathrm{F}-32\right) / 1.8$

Vertical coordinate information is referenced to the North American Vertical Datum of 1988 (NAVD 88).

Horizontal coordinate information is referenced to the North American Datum of 1983 (NAD 83).

Altitude, as used in this report, refers to distance above the vertical datum.

Specific conductance is given in microsiemens per centimeter at 25 degrees Celsius $(\mu \mathrm{S} / \mathrm{cm}$ at $\left.25^{\circ} \mathrm{C}\right)$.

Concentrations of chemical constituents in water are given either in milligrams per liter (mg/L) or micrograms per liter $(\mu \mathrm{g} / \mathrm{L})$. 


\title{
Groundwater-Quality Monitoring Program in Chester County, Pennsylvania, 1980-2008
}

\author{
By Lisa A. Senior and Ronald A. Sloto
}

\section{Abstract}

The U.S. Geological Survey in cooperation with the Chester County Water Resources Authority and the Chester County Health Department began a groundwater-quality monitoring program in 1980 in Chester County, Pa., where a large percentage of the population relies on wells for drinkingwater supply. This report documents the program and serves as a reference for data collected through the program from 1980 through 2008.

The initial focus of the program was to collect data on groundwater quality near suspected localized sources of contamination, such as uncontrolled landfills and suspected industrial wastes, to determine if contaminants were present that might pose a health risk to those using the groundwater. Subsequently, the program was expanded to address the effects of widely distributed contaminant sources associated with agricultural and residential land uses on groundwater quality and to document naturally occurring constituents, such as radium, radon, and arsenic, that are potential hazards in drinking water. Since 2000, base-flow stream samples have been collected in addition to well-water and spring samples in a few small drainage areas to investigate the relation between groundwater quality and stream base-flow quality. The program has primarily consisted of spatial assessment with limited temporal data collected on groundwater quality. Most data were collected through the monitoring program for reconnaissance purposes to identify and locate groundwater-quality problems and generally were not intended for rigorous statistical analyses that might determine land-use or geochemical factors affecting groundwater quality in space or through time.

Results of the program found several contaminants associated with various land uses and human activities in groundwater in Chester County. Volatile organic compounds (such as trichloroethylene) were measured in groundwater near suspected localized contaminant sources in concentrations that exceeded drinking-water standards. Groundwater in some agricultural areas had concentrations of nitrate and some pesticides that exceeded drinking-water standards. Elevated concentrations of chloride were measured near salt storage areas and highways. Formaldehyde was detected in groundwater near cemeteries. In residential areas with on-site wastewater disposal, effects on groundwater quality included elevated nitrate concentrations and low concentrations of volatile organic compounds and wastewater compounds, such as antibiotics and detergents. Base-flow samples indicated that groundwater discharge to streams carried contaminants such as nitrate, pesticides, wastewater compounds, and other contaminants.

Radionuclides, including radium-226, radium-228, radium-224, and radon-222, and gross alpha-particle activity were measured in groundwater at levels above established and proposed drinking-water standards in some geologic units, particularly in quartzite and quartzite schists. Arsenic concentrations above drinking-water standards were measured in a few samples and were most likely to occur in groundwater in the shales and sandstones in the northern part of the county. Other potential natural hazards, such as lead from aquifer materials or leached from plumbing because of low $\mathrm{pH}$, were present in concentrations above drinking-water standards infrequently (less than 10 percent of samples).

Limited temporal sampling suggested that chloride concentrations in groundwater increased in the county since the program began in 1980 through 2008, reflecting increasing population and urbanization in that period.

\section{Introduction}

The groundwater-quality monitoring program conducted by the U.S. Geological Survey (USGS), in cooperation with the Chester County Water Resources Authority (CCWRA) and the Chester County Health Department (CCHD), in Chester County, Pa., began in 1980 in response to environmental health concerns of the time. In the late 1970 s, contamination of the environment, including groundwater, from landfills and various commercial and industrial waste-disposal activities had become an issue in the United States, prompting the U.S. Congress to pass the Comprehensive Environmental Response, Compensation and Liability Act (CERCLA) of 1980 to address the identification and cleanup of contaminated areas. Because groundwater is an important source of water supply for domestic use in Chester County and because of the public-health concerns in the county, the CCWRA and the 
CCHD wanted to obtain information about the extent, magnitude, and type of possible groundwater contamination, such as that being addressed under CERCLA (also known as Superfund). Thus, the CCWRA and CCHD worked with USGS to establish the Chester County groundwater-quality monitoring program to gather data for use in protecting the environment and public health of Chester County.

For the first few years, the focus of the monitoring program was in areas near suspected sources of uncontrolled landfill and industrial contamination. Through time, the program broadened in scope to include investigations of other sources of contamination including naturally occurring constituents that could pose risks to human health and the potential effects of various land uses. The monitoring program also supported other water-resource studies undertaken by USGS for the county.

\section{Purpose and Scope}

This report describes and documents the Chester County groundwater-quality monitoring program conducted by the USGS from its inception in 1980 through 2008. Results of sampling are summarized for each type of potential contaminant source targeted by the monitoring program. Results that have not been discussed in previous reports, including data collected after 2001, are presented with more detail.

In addition, the sampled sites are listed in an appendix by year, including the site identification numbers and the reason for sample collection. This reference appendix can be used to obtain detailed data from the USGS water-quality database for each site sampled.

\section{Description of Study Area}

Chester County is about $760 \mathrm{mi}^{2}$ in area and lies in the Piedmont Physiographic Province in southeastern Pennsylvania. The topography is generally characterized by rolling hills and ranges in elevation from about 150 to $1,000 \mathrm{ft}$ above NAVD 88 . The county has a humid temperate climate and receives an average total annual precipitation of about 48 in. [30-year normal (1971-2000) precipitation for meteorological station West Chester $2 \mathrm{NW}$ is 47.89 in. (National Oceanic and Atmospheric Administration, 2005)], which is distributed nearly evenly throughout the year. Chester County has 73 municipalities including 1 city (Coatesville), 15 boroughs, and 57 townships (see appendix).

\section{Hydrogeologic Setting}

The relatively complex geology of Chester County is made up of about 40 different mapped bedrock units consisting of Paleozoic-age and older metamorphic rocks, including phyllite, schist, limestone, marble, quartzite, and gneiss, and Mesozoic-age sedimentary (Triassic-age) and intrusive (Triassic- and Jurassic-age) rocks (fig. 1). Carbonate rocks, which are less resistant to erosion than the adjacent noncarbonate rocks, underlie the main east-west valley crossing the county. A more complete description of the geologic units in Chester County is given by Sloto (1994), although more recent geologic mapping in the southern two thirds of the county (Blackmer, 2004a, 2004b, 2005; Blackmer and Brown, 2006; Bosbyshell, 2006; Brown, 2006; Hill, 2006; Marquez, 2005; Wiswall, 2005) may supersede earlier mapping (Sloto, 1994) in some areas. Unconsolidated units consist of thin alluvial deposits that are quaternary in age or younger. Geologic names used in this report follow nomenclature established by the Pennsylvania Geological Survey and may not conform to USGS usage.

The rocks underlying Chester County form fractured-rock aquifers, where weathered bedrock (saprolite) and soil overlie the competent bedrock. Water-bearing properties differ by geologic unit (Sloto, 1994). Thickness of the saprolite varies but commonly is 10 to $40 \mathrm{ft}$. Soils in much of the county are moderately deep and well-drained, although the soils are thin and (or) poorly drained in some areas (Kunkle, 1963). Drilled wells generally are completed as open holes in the bedrock, with casing extending through the saprolite to the top of competent bedrock. Hand-dug wells dating from the period before drilled wells were common (by the early 20th century) generally are completed in the saprolite. Unconsolidated deposits in the county generally are not used as aquifers.

The fractured-rock aquifers are recharged locally by precipitation infiltrating through soils and saprolite to the bedrock. Groundwater flows through fracture openings in the bedrock and also in the saturated part of the saprolite. Under natural conditions, groundwater discharges to streams and springs. The water table generally is a subdued replica of the land surface, as shown by 27 maps of groundwater levels in the county (U.S. Geological Survey, 2006), such that groundwater flow paths commonly follow topography. Base flow (supplied by groundwater discharge to streams) comprises about 60 percent of total annual streamflow on average, as estimated from water budgets for several streams in Chester County (Sloto, 1994), and may be as high as about 80 percent of streamflow (Cinotto and others, 2005, p. 21).

Depth to water typically varies by topography; depths to water are greater under hilltops than on slopes or in valleys. Groundwater levels fluctuate seasonally because of changes in net recharge rates; depth to water is greatest in the fall and least in the spring. Although precipitation is distributed nearly evenly throughout the year, net recharge generally is greater in the cooler months (October-April), when evapotranspiration is reduced, than in the warmer months (May-September). Longterm average groundwater levels and base flow are highest in spring and lowest in fall in Chester County, Pa.

\section{Land Use}

Land use in Chester County is mixed, consisting largely of different types of agriculture (such as row crops, hay, mushroom growing and composting, nurseries, orchards, and dairy) 


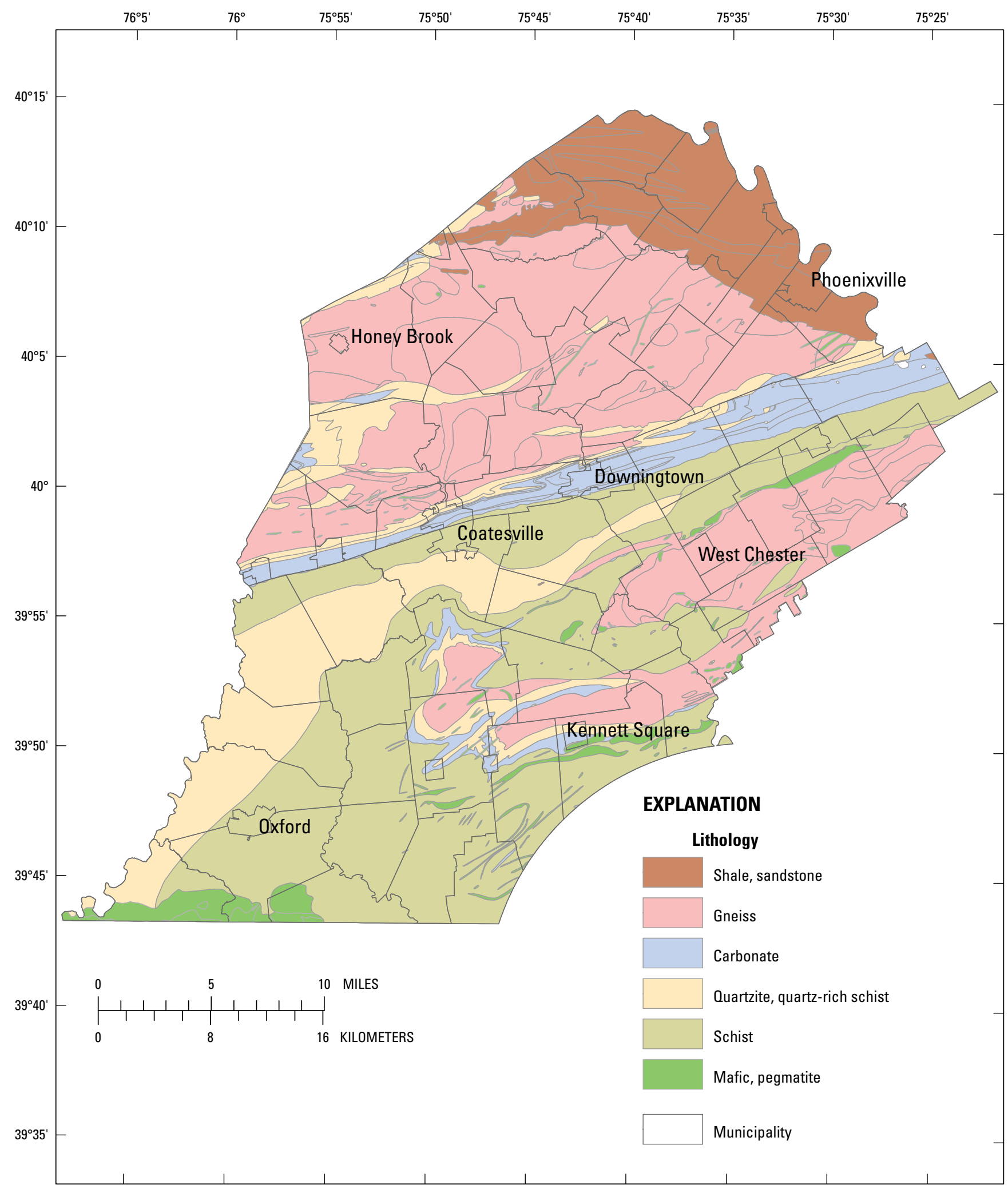

Figure 1. Generalized geology of Chester County, $\mathrm{Pa}$. 
with lesser amounts of wooded, residential, and other uses. In 2000 , about 39 percent of the land was agricultural, 27 percent wooded, 18 percent residential (mostly single-family), 11 percent industrial/commercial (including transportation and parking), and about 5 percent open, recreational, or vacant (fig. 2) (Delaware Valley Regional Planning Commission, 2004). In 2005, the date of the most recent reported land use available, the relative proportion of each type of land use in the county was similar to the distribution in 2000 but with decreases in agricultural and undeveloped uses and increases in residential and other developed uses (industrial/commercial/transportation) (Delaware Valley Regional Planning Commission, 2008, 2009).

Since the groundwater-quality monitoring program began in 1980, the amount of land in agricultural and forested uses decreased, and the amount of land in residential and commercial uses increased. From 1980 to 2000, the population in Chester County increased by 36.9 percent $(116,841$ people) (Delaware Regional Valley Planning Commission, 2001). From 2000 to 2005, the population increased 9 percent from 433,510 to 473,880 (Delaware Valley Regional Planning Commission, 2009). This urbanizing trend is expected to continue. The population in Chester County is estimated to increase by 31 percent (148,618 people) from 2005 to 2035 (Delaware Valley Regional Planning Commission, 2007).

Human activities associated with many land uses have the potential to change the quality of groundwater, including the introduction of contaminants that may pose a risk to human health. Some human activities or land uses may be a source of several contaminants. Some contaminants may have more than one source. For example, the presence of pesticides and elevated nitrate concentrations in groundwater may be associated with some agricultural activities. However, elevated nitrate in groundwater may be introduced not only through use of fertilizers in agricultural areas but also through on-site residential wastewater disposal, including septic systems. Possible contaminants or constituents of concern in groundwater that are commonly associated with various land uses are listed in table 1 .

\section{Previous Studies}

Results of the Chester County groundwater-quality monitoring program have been published in part in several reports. Data collected through the program have been compiled with data collected for other studies in a data report by Sloto (1989) and in interpretive reports by Sloto $(1990,1994,2000)$, Senior and others (1997), Senior (1998), and Ludlow and Loper (2004). Groundwater-quality data, including that collected as part of the groundwater-quality monitoring program and other studies, were compiled through 2001 in the most recent comprehensive interpretive report (Ludlow and Loper, 2004) and are discussed by constituent, with maps showing the distribution of concentrations that meet or exceed drinking-water standards or other statistical measures. The report by Ludlow and Loper (2004), however, does not include data collected prior to 1990 during the first 10 years of the Chester County groundwater-quality monitoring program for some constituents [common ions, metals, nutrients, pesticides, and volatile organic compounds (VOCs)].

Data collected solely through the Chester County groundwater-quality monitoring program were used to support the investigation of radium-224 (Senior and Sloto, 2000), the Elk Creek Basin study (Sloto, 2002), and a pilot study of the effect of on-site wastewater disposal on the quality of groundwater and base flow (Senior and Cinotto, 2007). Data collected largely through the groundwater-quality monitoring program were used to assess the occurrence of radon-222 in groundwater throughout the county (Senior, 1998). In addition, data collected through the program have been published with site location maps but without interpretation annually since 2000 (Durlin and Schaffstall, 2001a, 2001b, 2002, 2003, 2005; Durlin and others, 2006; U.S. Geological Survey, 2007, 2008, 2009).

Other USGS reports that describe aspects of groundwater quality in Chester County were based on studies funded and conducted separately from the monitoring program. These studies included effects of urbanization on eastern Chester County (Sloto, 1987), radium and radon in groundwater (Senior and Vogel, 1995), Red Clay Creek Basin assessment

Table 1. Contaminants or constituents of concern in groundwater that are commonly associated with various land uses for the Chester County groundwater-quality monitoring program, 1980-2008.

[VOCs, volatile organic compounds]

\begin{tabular}{ll}
\hline \multicolumn{1}{c}{ Land use } & \multicolumn{1}{c}{ Contaminants or constituents of concern commonly associated with land use } \\
\hline Uncontrolled landfill, dump & VOCs, ammonia, iron, manganese, trace metals \\
Industrial wastes & VOCs, trace metals \\
Agricultural & Pesticides, elevated nutrients (nitrate, phosphate) \\
Roads & Chloride, sodium \\
Residential with on-site wastewater disposal & Elevated nutrients (nitrate, phosphate), VOCs, boron, chloride, organic wastewater compounds \\
\hline
\end{tabular}




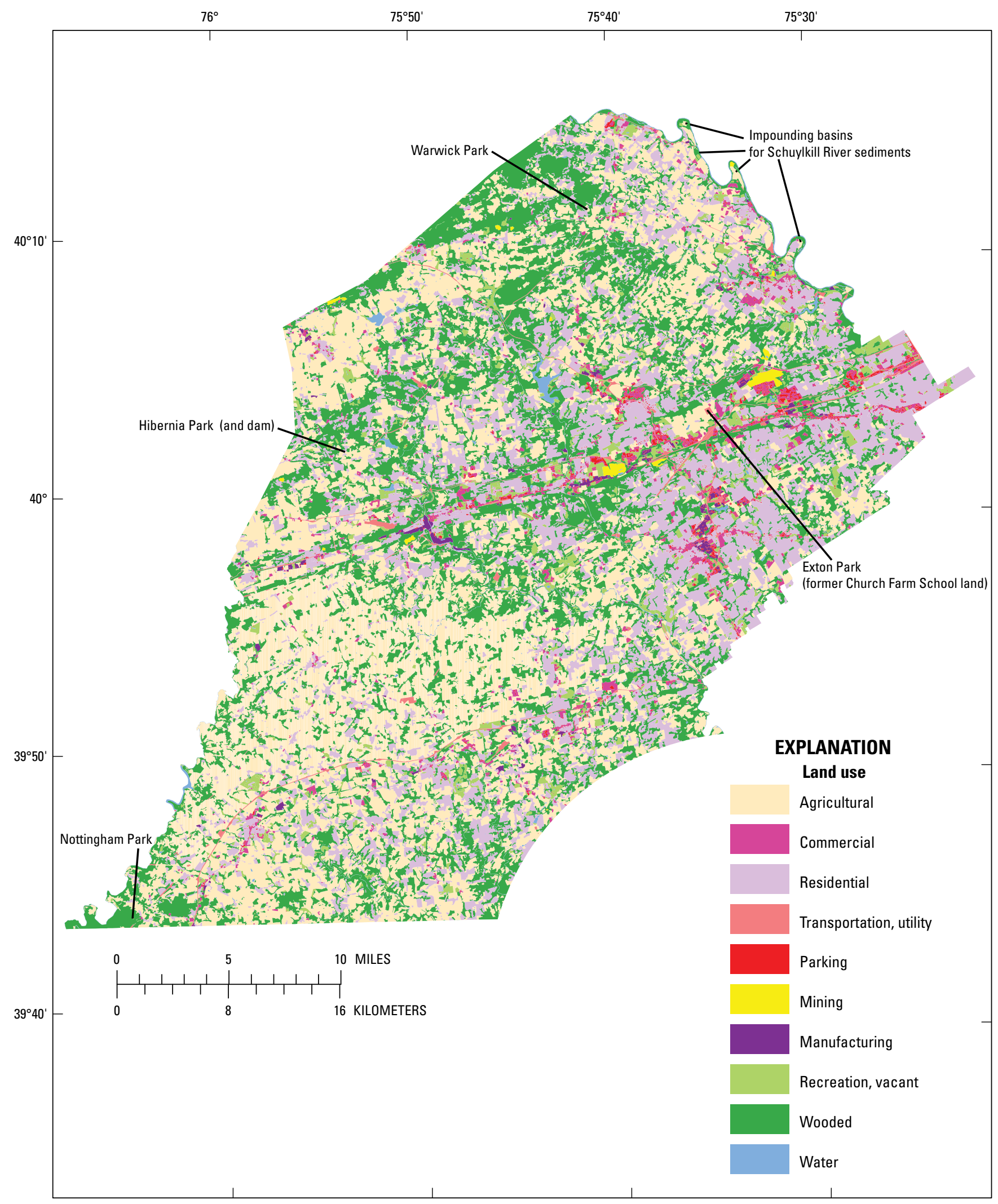

Figure 2. Land use in 2000 in Chester County, Pa., and location of selected parks and other county-owned land. 
(Senior, 1996), microbiological quality (Lindsey and others, 2002), and effects of spray irrigation (Schreffler and others, 2005). USGS reports by Sloto $(1997,2001)$ describe aspects of groundwater contamination related to two Superfund sites in Chester County.

\section{Well, Spring, and Stream Identification System}

Each well and spring is identified by a local number (or name) and a 15-digit station identification number that is based on the latitude and longitude. In the text of the report, wells and springs are referred to by their local number, which consists of a county-abbreviation prefix followed by a sequentially assigned number. The prefix $\mathrm{CH}$ denotes a well and CH-SP denotes a spring in Chester County. In the appendix, sampled wells and springs are listed by the local number and the 15-digit station identification number. A few surfacewater sites are also identified by a 15-digit station identification number.

Stream sites generally are identified by a station identification number assigned in downstream order, typically eight or more digits in length and which is explained in more detail in Durlin and Schaffstall (1999) for example. The stream site name gives the name of the stream and nearby named geographic features such as a road or town.

\section{Chester County Groundwater-Quality Monitoring Program}

The Chester County groundwater-quality monitoring program consists of the annual collection of groundwater and occasional stream base-flow samples at various sites selected each year to assess potential risks to human health or other environmental concerns. Sample locations and analyses are selected by USGS in consultation with the CCWRA and CCHD to meet one or more of the following objec-

tives: (1) to provide data on groundwater quality near suspected sources of contamination; (2) to provide data that could be used to assess effects of land-use activities on groundwater and stream base-flow quality; (3) to provide data on naturally occurring constituents in groundwater that may pose a health risk; and (4) to informally monitor changes in groundwater quality near known sources of contamination.

The monitoring program was initially driven by interest in obtaining data on groundwater quality near suspected point sources of contamination, such as uncontrolled landfills (dumps) and industrial on-site waste discharges. Later, especially after 1985 , the program evolved to investigate the effects of other land-use activities on groundwater and base-flow quality and the distribution of naturally occurring constituents that may be harmful to human health, such as arsenic, radium, and radon. The number of samples collected each year and the type of source targeted for sample collection are listed in table 2. A detailed listing and locations of wells, springs, or streams (base-flow sites) sampled each year from 1980 through 2008 are given in appendix 1. The sample locations also may be obtained through the web interface http://nwis.waterdata.usgs.gov/pa/nwis/qwdata by searching by county and the site number (station number) listed in appendix 1 and then selecting site map from list of available data for the site. The locations of all stream sites and wells with hydrologic data, including water-quality data, in Pennsylvania may be obtained through the web interface http://wdr.water.usgs.gov/nwisgmap/?state $=p a$.

The focus of the groundwater-monitoring program was a spatial rather than temporal assessment of groundwater quality. However, groundwater quality can change through time because of (1) changes in land use and sources at the land surface, recharge, and groundwater-flow directions, or (2) transport and chemical reactions in the aquifer. Changes in groundwater quality may result in constituent concentrations that exceed water-quality standards and therefore pose increased risks to human health or have other adverse effects on non-consumptive water use. Some variability in groundwater quality may be seasonal if related to the natural hydrologic cycle; other variability may show a trend reflecting long-term changes in land use.

Although most samples were collected to determine the location and extent of possible groundwater-quality problems in the county, a few wells were sampled more than once to provide data on groundwater quality through time. Some wells were resampled periodically over a few years to evaluate persistence of contaminants or, on regular intervals for 2 years in the radon study (Senior, 1998), to evaluate seasonal fluctuations. Wells resampled for different assessments occasionally yielded data on concentrations of selected constituents at various time intervals.

Base-flow samples were collected for the monitoring program in small or headwater streams to provide data on the relation between the quality of groundwater and surface water. Groundwater discharge to streams is the source of stream base flow. Some constituents dissolved in groundwater, especially relatively soluble constituents that are not adsorbed onto soils or aquifer materials or readily degraded in the groundwater system, may be transported in groundwater and discharge to streams in the drainage area.

Sampling needs for the monitoring program typically were defined in the spring of each year, and sites are sampled the following summer. The number of sites sampled each year has ranged from 6 to 61, depending on the need and the costs of sample collection and analysis. No samples were collected in 2004. The USGS collected samples mostly from domestic wells but also from non-domestic production wells and a few springs. Samples were collected using standard techniques (U.S. Geological Survey, variously dated) and analyzed by the USGS National Water Quality Laboratory (NWQL) for most constituents. For some constituents, such as formaldehyde and most radiochemicals, laboratories under contract to the NWQL performed the analyses. All NWQL water-quality data 


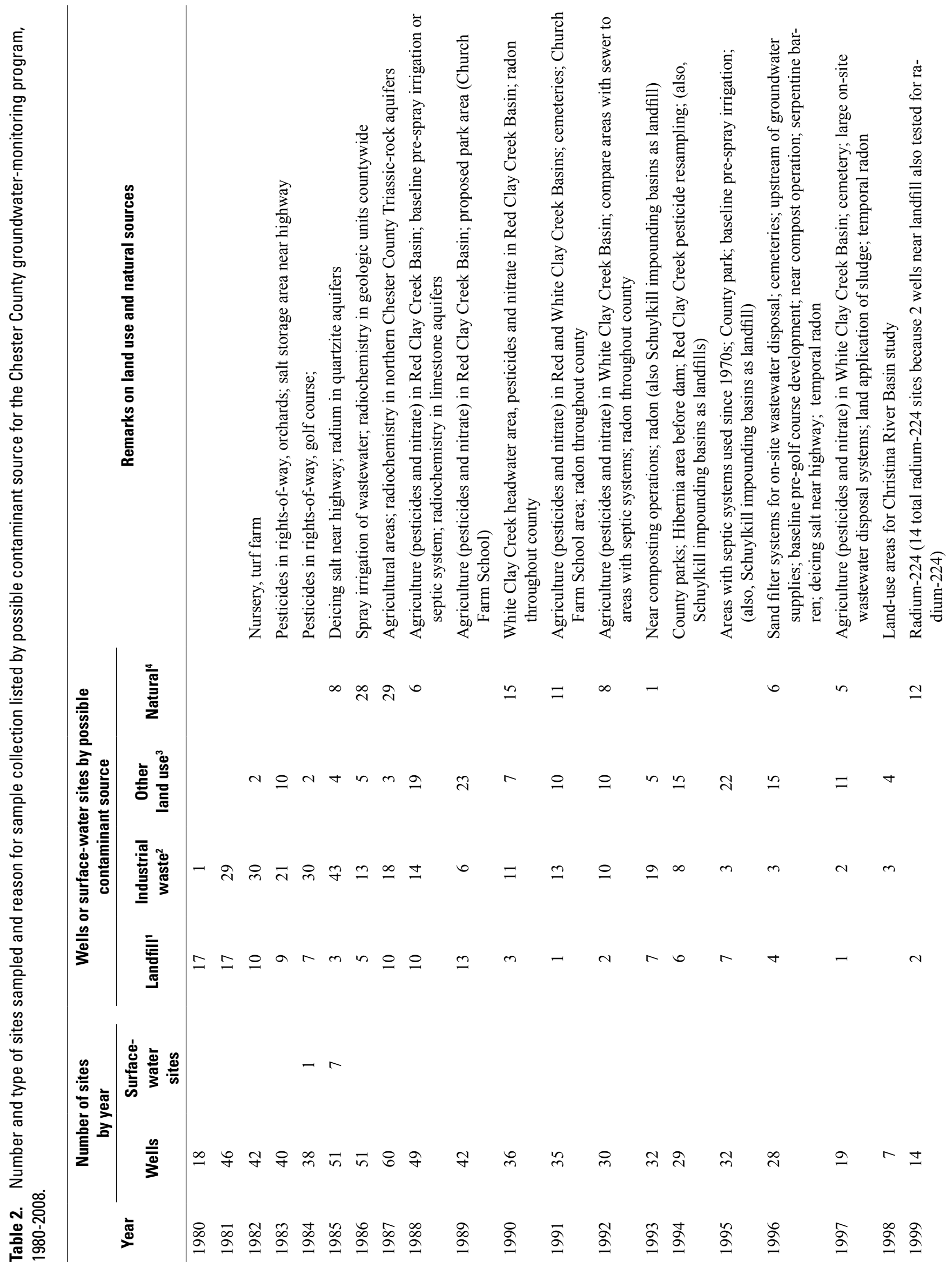




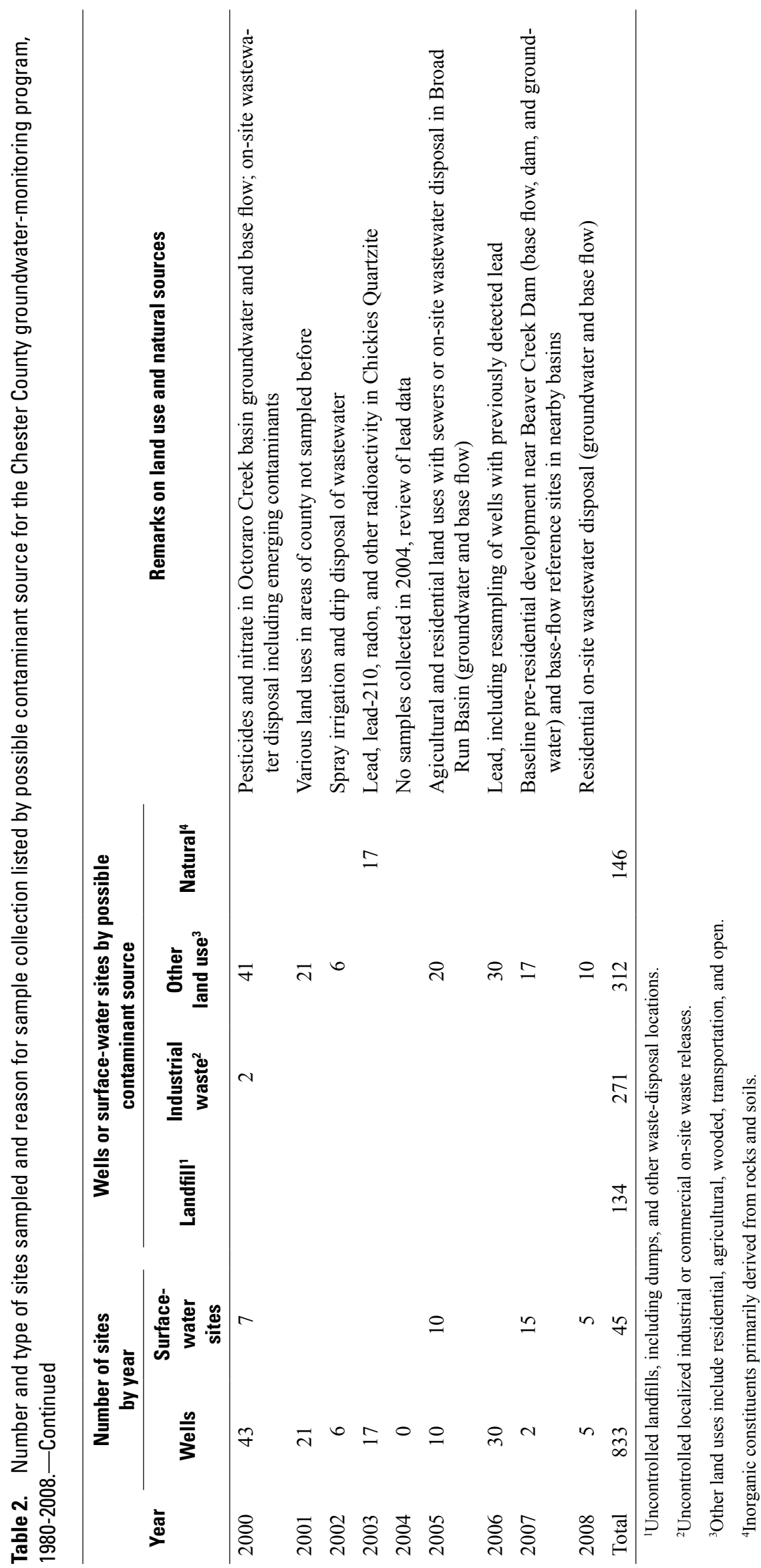


are stored in USGS databases and are available to the public (http://nwis.waterdata.usgs.gov/pa/nwis/qwdata).

The types of analyses performed on the water samples were selected to target suspected contaminants or other constituents of interest. In addition, especially after 1988, samples commonly also were analyzed for major ions, such as calcium, sodium, and chloride, and basic nutrients, such as nitrate and phosphate, to provide information about general water quality and the distribution of these constituents countywide. Selected groundwater samples from 1986 through 1988 and most groundwater samples from 1989 through 2003 were analyzed for radon-222, a radioactive gas that is the product of radium-226 decay in the uranium-238 decay chain.

Only one or two quality control (QC) samples were collected each year as part of the monitoring program because of the limited annual funding and scope of the program (being reconnaissance in nature). Most samples collected for QC purposes were environmental replicates, and these data are available in the USGS databases for review. Replicates typically were assigned a sample time that is 1 minute apart. For analyses of the organic wastewater compounds and pharmaceuticals in 2008 that are reported in parts per trillion, the QC sample consisted of a blank in which no compounds were detected. In general, few QC problems were identified with the limited QC.

This report briefly summarizes results of the monitoring program only from 1980 through 2008 and, in contrast to previous reports, is organized by potential sources of contaminants or constituents. These sources are either natural or related to human activities, such as agricultural, commercial, industrial, and residential development, and waste disposal, all of which have the potential to affect groundwater quality. Localized activities, such as landfills or industrial waste disposal, may affect groundwater quality only nearby or in some cases, such as in the carbonate aquifers, may be transported thousands of feet from the contaminant source. More widely spatially distributed activities, such as residential or agricultural land uses, may affect groundwater quality over large areas. Results of the monitoring program that have not been discussed in previous reports, including data collected from 2001 through 2008, are presented in greatest detail in this report.

\section{Results of Sampling for Constituents Associated with Land Uses and Human Activities}

Results of sampling in targeted areas showed that contaminants associated with various sources commonly were detected in groundwater and sometimes in base flow near those sources. The results for contaminants and constituents detected in the targeted areas are summarized for each type of source in the following sections.

Contaminants, where detected, were present at trace levels to concentrations that exceeded maximum contaminant levels (MCLs), health advisories (HAs), or other values such as drinking-water equivalent levels (DWELs) listed by the U.S. Environmental Protection Agency (USEPA) to protect human health for those constituents in drinking water (U.S. Environmental Protection Agency, 2009a). Many compounds or constituents that may be present in groundwater do not have established MCLs, which are regulatory primary drinkingwater standards, but may pose a risk to human health in drinking water, and USEPA lists other non-regulatory levels, such as HAs and DWELs, for some of these compounds and constituents. The MCLs and HAs for selected constituents commonly detected in groundwater in Chester County are listed in table 3.

The MCLs established by the USEPA are required for public drinking-water supplies but may be used as guidelines for private well owners whose water generally is not regulated in Pennsylvania. However, for private well owners in Chester County, the CCHD does require that tap water from new wells meet turbidity, nitrate, and bacteria standards for public health protection. Secondary maximum contaminant levels (SMCLs) established by the USEPA are other non-regulatory guidelines established for aesthetic reasons such as taste and odor (U.S. Environmental Protection Agency, 2009a).

\section{Uncontrolled Landfills, Dumps, and Industrial Waste Discharges}

Groundwater sampling near uncontrolled landfills, dumps, and industrial waste discharge areas occurred primarily during the first 10 years of the monitoring program and tapered off during the next 10 years after many of the sources of uncontrolled contaminants were identified. From 1980 through 1989, 82 samples were collected near uncontrolled landfills and dumps, and 172 samples were collected near industries. From 1990 through 2000, a total of 105 samples was collected near uncontrolled landfills or industries, and after 2000, no samples were collected near those types of sources. Samples near uncontrolled landfills or industries were analyzed for selected metals; one or more types of anthropogenic organic compounds, including VOCs such as trichloroethylene (TCE) and tetrachloroethylene (PCE); acidextractable compounds, such as phenol; gross phenols; baseneutral-extractable organic compounds, such as napthalene; polychlorinated biphenyls (PCBs); polychlorinated napthalenes (PCNs); and (or) organochlorine insecticides, such as dichlorodiphenyltrichloroethane (DDT).

Locations sampled during the first 10 years of the program generally showed higher levels of groundwater contamination by solvents, such as TCE and PCE, than those sampled after 1990 because of differences in the areas targeted for sampling. Of the VOCs analyzed from 1980 through 2001, TCE was the most frequently detected, with concentrations up to $4,400 \mu \mathrm{g} / \mathrm{L}$. Concentrations greater than $100 \mu \mathrm{g} / \mathrm{L}$ were measured in samples collected from 15 wells during 1980-89 (Sloto, 1989, 1994). In contrast, the greatest TCE concentration measured in samples collected during 1990-2001 was 
Table 3. Maximum contaminant levels, health advisories, and secondary maximum contaminant levels established by the U.S. Environmental Protection Agency (2009) for selected constituents in drinking water.

[MCL, maximum contaminant level; HA, lifetime health advisory, unless noted; SMCL, secondary maximum contaminant level; $\mu \mathrm{g} / \mathrm{L}$, micrograms per liter; $\mathrm{mg} / \mathrm{L}$, milligrams per liter; $\mathrm{mg} / \mathrm{L}$ as $\mathrm{N}$, milligrams per liter as nitrgen; $\mathrm{pCi} / \mathrm{L}$, picocuries per liter; mrem/yr, millirem per year; DWEL, drinking-water equivalent level; --, no standard]

\begin{tabular}{|c|c|c|c|c|c|}
\hline Compounds & Units & MCL & HA & SMCL & Remarks \\
\hline \multicolumn{6}{|c|}{ Industrial compound/solvents } \\
\hline 1,1-dichloroethylene & $\mu \mathrm{g} / \mathrm{L}$ & 7 & 2,000 & -- & DWEL HA, $10^{-4}$ cancer risk is $6 \mu \mathrm{g} / \mathrm{L}$ \\
\hline 1,1,1-trichloroethane & $\mu \mathrm{g} / \mathrm{L}$ & 200 & 70,000 & -- & DWEL HA \\
\hline Formaldehyde & $\mathrm{mg} / \mathrm{L}$ & -- & 1 & -- & \\
\hline Napthalene & $\mu \mathrm{g} / \mathrm{L}$ & -- & 100 & -- & \\
\hline PCBs & $\mu \mathrm{g} / \mathrm{L}$ & .5 & -- & -- & $10^{-4}$ cancer risk is $10 \mu \mathrm{g} / \mathrm{L}$ \\
\hline Phenol & $\mathrm{mg} / \mathrm{L}$ & -- & 2 & -- & \\
\hline Tetrachloroethylene & $\mu \mathrm{g} / \mathrm{L}$ & 5 & 10 & -- & \\
\hline Trichloroethylene & $\mu \mathrm{g} / \mathrm{L}$ & 5 & 200 & -- & DWEL HA \\
\hline Trihalomethanes (total) $^{1}$ & $\mu \mathrm{g} / \mathrm{L}$ & 80 & 70 & -- & \\
\hline \multicolumn{6}{|l|}{ Pesticides } \\
\hline Alachlor & $\mu \mathrm{g} / \mathrm{L}$ & 2 & 400 & -- & DWEL HA, $10^{-4}$ cancer risk is $4 \mu \mathrm{g} / \mathrm{L}$ \\
\hline Atrazine & $\mu \mathrm{g} / \mathrm{L}$ & 3 & 700 & -- & DWEL HA \\
\hline Ametryn & $\mu \mathrm{g} / \mathrm{L}$ & -- & 60 & -- & \\
\hline Carbaryl & $\mu \mathrm{g} / \mathrm{L}$ & -- & 400 & -- & DWEL HA \\
\hline Carbofuran & $\mu \mathrm{g} / \mathrm{L}$ & 40 & -- & -- & \\
\hline Chlordane & $\mu \mathrm{g} / \mathrm{L}$ & 2 & 20 & -- & DWEL HA, $10^{-4}$ cancer risk is $10 \mu \mathrm{g} / \mathrm{L}$ \\
\hline Diazinon & $\mu \mathrm{g} / \mathrm{L}$ & -- & 1 & -- & \\
\hline Dieldrin & $\mu \mathrm{g} / \mathrm{L}$ & -- & 2 & -- & DWEL HA, $10^{-4}$ cancer risk is $0.2 \mu \mathrm{g} / \mathrm{L}$ \\
\hline Lindane & $\mu \mathrm{g} / \mathrm{L}$ & .2 & 200 & -- & DWEL HA \\
\hline Malathion & $\mu \mathrm{g} / \mathrm{L}$ & -- & 500 & -- & \\
\hline Methoxychlor & $\mu \mathrm{g} / \mathrm{L}$ & 40 & 40 & -- & \\
\hline Metolachlor & $\mu \mathrm{g} / \mathrm{L}$ & -- & 700 & -- & \\
\hline Prometon & $\mu \mathrm{g} / \mathrm{L}$ & -- & 400 & -- & \\
\hline Propazine & $\mu \mathrm{g} / \mathrm{L}$ & -- & 100 & -- & \\
\hline Silvex $(2,4,5-\mathrm{TP})$ & $\mu \mathrm{g} / \mathrm{L}$ & 50 & 50 & -- & \\
\hline Simazine & $\mu \mathrm{g} / \mathrm{L}$ & 4 & 700 & -- & DWEL HA \\
\hline Tebuthiuron & $\mu \mathrm{g} / \mathrm{L}$ & -- & 500 & -- & \\
\hline Terbacil & $\mu \mathrm{g} / \mathrm{L}$ & -- & 90 & -- & \\
\hline Trifluralin & $\mu \mathrm{g} / \mathrm{L}$ & -- & 10 & -- & \\
\hline \multicolumn{6}{|l|}{ Metals and inorganics } \\
\hline Arsenic & $\mu \mathrm{g} / \mathrm{L}$ & 10 & 2 & -- & $10^{-4}$ cancer risk for $\mathrm{HA}$ \\
\hline Boron & $\mu \mathrm{g} / \mathrm{L}$ & -- & 6,000 & -- & \\
\hline Cadmium & $\mu \mathrm{g} / \mathrm{L}$ & 5 & 5 & -- & \\
\hline Chloride & $\mathrm{mg} / \mathrm{L}$ & -- & -- & 250 & \\
\hline Chromium (total) & $\mu \mathrm{g} / \mathrm{L}$ & 100 & 100 & -- & DWEL HA \\
\hline Cyanide & $\mu \mathrm{g} / \mathrm{L}$ & 200 & 200 & -- & \\
\hline Iron & $\mu \mathrm{g} / \mathrm{L}$ & -- & -- & 300 & \\
\hline Lead & $\mu \mathrm{g} / \mathrm{L}$ & ${ }^{2} 15$ & -- & -- & \\
\hline Manganese & $\mu \mathrm{g} / \mathrm{L}$ & -- & 300 & 50 & \\
\hline
\end{tabular}


Table 3. Maximum contaminant levels, health advisories, and secondary maximum contaminant levels established by the U.S. Environmental Protection Agency (2009) for selected constituents in drinking water.-Continued

[MCL, maximum contaminant level; HA, lifetime health advisory, unless noted; SMCL, secondary maximum contaminant level; $\mu \mathrm{g} / \mathrm{L}$, micrograms per liter; $\mathrm{mg} / \mathrm{L}$, milligrams per liter; $\mathrm{mg} / \mathrm{L}$ as $\mathrm{N}$, milligrams per liter as nitrgen; $\mathrm{pCi} / \mathrm{L}$, picocuries per liter; mrem/yr, millirem per year; DWEL, drinking-water equivalent level; --, no standard]

\begin{tabular}{|c|c|c|c|c|c|}
\hline Compounds & Units & MCL & HA & SMCL & Remarks \\
\hline \multicolumn{6}{|l|}{ Metals and inorganics-Continued } \\
\hline Mercury (inorganic) & $\mu \mathrm{g} / \mathrm{L}$ & 2 & 2 & -- & \\
\hline Molybdenum & $\mu \mathrm{g} / \mathrm{L}$ & -- & 40 & -- & \\
\hline Nickel & $\mu \mathrm{g} / \mathrm{L}$ & -- & 100 & -- & \\
\hline Nitrate (as nitrogen) & $\mathrm{mg} / \mathrm{L}$ as $\mathrm{N}$ & 10 & -- & -- & \\
\hline Nitrite (as nitrogen) & $\mathrm{mg} / \mathrm{L}$ as $\mathrm{N}$ & 1 & -- & -- & \\
\hline Silver & $\mu \mathrm{g} / \mathrm{L}$ & -- & 100 & 100 & \\
\hline Zinc & $\mu \mathrm{g} / \mathrm{L}$ & -- & 2,000 & 5,000 & \\
\hline \multicolumn{6}{|l|}{ Radionuclides } \\
\hline Gross beta-particle and photon activity & $\mathrm{mrem} / \mathrm{yr}$ & 4 & -- & -- & \\
\hline Gross alpha-particle activity & $\mathrm{pCi} / \mathrm{L}$ & 15 & -- & -- & \\
\hline Radium-226 and radium-228 3 & $\mathrm{pCi} / \mathrm{L}$ & 5 & -- & -- & \\
\hline Radon-222 & $\mathrm{pCi} / \mathrm{L}$ & ${ }^{4} 300$ & -- & -- & $10^{-4}$ cancer risk is $150 \mathrm{pCi} / \mathrm{L}$ \\
\hline Uranium & $\mu \mathrm{g} / \mathrm{L}$ & 30 & -- & -- & \\
\hline \multicolumn{6}{|l|}{ 'Includes chloroform (trichloromethane). } \\
\hline \multicolumn{6}{|l|}{${ }^{2}$ Action level. } \\
\hline${ }^{3}$ Combined radium-226 and radium-228. & & & & & \\
\hline
\end{tabular}

$95 \mu \mathrm{g} / \mathrm{L}$ (Ludlow and Loper, 2004). Samples from 32 (14 percent) of 225 wells sampled before 1990 had concentrations of TCE that were greater than the MCL of $5 \mu \mathrm{g} / \mathrm{L}$ (Sloto, 1994), whereas samples from only 2 percent of 187 wells sampled from 1990 through 2001 (Ludlow and Loper, 2004) had concentrations of TCE greater than $5 \mu \mathrm{g} / \mathrm{L}$. Overall from 1980 through 2008, TCE concentrations greater than the MCL of $5 \mu \mathrm{g} / \mathrm{L}$ were measured in samples from 47 wells. Concentrations of other detected VOCs, including PCE, 1,1,1-trichloroethane (TCA), 1,1-dichloroethylene (DCE), 1,2-dichloroethane (DCA), benzene, carbon tetrachloride, and styrene, exceeded USEPA MCLs in 1 to 4 percent of samples collected before 1990 but in less than 1 percent of samples collected from 1990 through 2001.

During the 1980s to early 1990s, when the focus of the groundwater-quality monitoring program was on discrete localized sources such as landfills, dumps, and industrial waste activities, 27 wells were sampled for VOCs two or more times over several years to verify continued presence of detected contaminants (table 4). Concentrations of detected VOCs were similar in samples from some wells (such as $\mathrm{CH}-2136$ and CH-3589), increased over time in some wells (CH-2403 and CH-2406), and decreased over time in some wells (CH-2448, $\mathrm{CH}-2449$, and $\mathrm{CH}-2676$ ). Variability in VOC concentrations is common near sources of contamination and may result in variable exceedances of drinking-water MCLs. For example, in samples collected from well CH-2406 in 1980, concentrations of PCE and TCE were less than the MCLs of $5 \mu \mathrm{g} / \mathrm{L}$ for those compounds but were considerably greater than $5 \mu \mathrm{g} / \mathrm{L}$ in 1981. These temporal VOC data show that results of a single sample cannot be used to represent water quality through time, especially if changes in sources, groundwater-flow directions, or other factors that affect groundwater quality are likely.

The elevated concentrations of anthropogenic organic compounds measured in wells sampled in the 1980s were used to help identify sites that eventually were placed on the USEPA National Priority List (NPL) to be remediated under CERCLA (Superfund) (fig. 3). Of the 11 sites placed on the NPL in Chester County, 9 were proposed for listing before 1990 on the basis of sampling results from the monitoring program (fig. 3). Samples collected through the monitoring program also helped to identify other areas of contamination that currently are being addressed by USEPA under the Resource Conservation and Recovery Act (RCRA) or by the Pennsylvania Department of Environmental Protection (PADEP). As of 2008, there were 15 RCRA sites in Chester County (U.S. Environmental Protection Agency, 2009b) (fig. 3). 


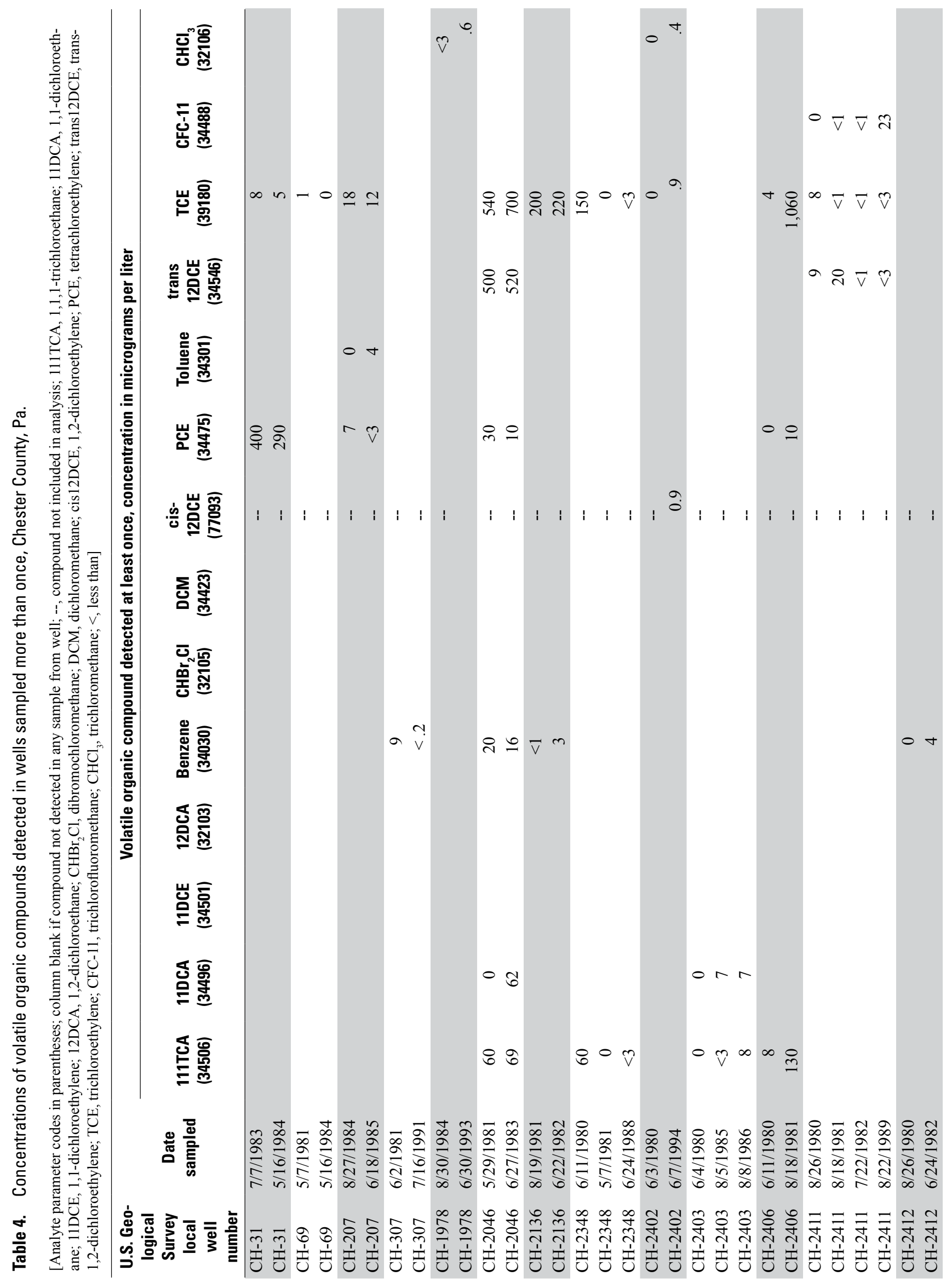




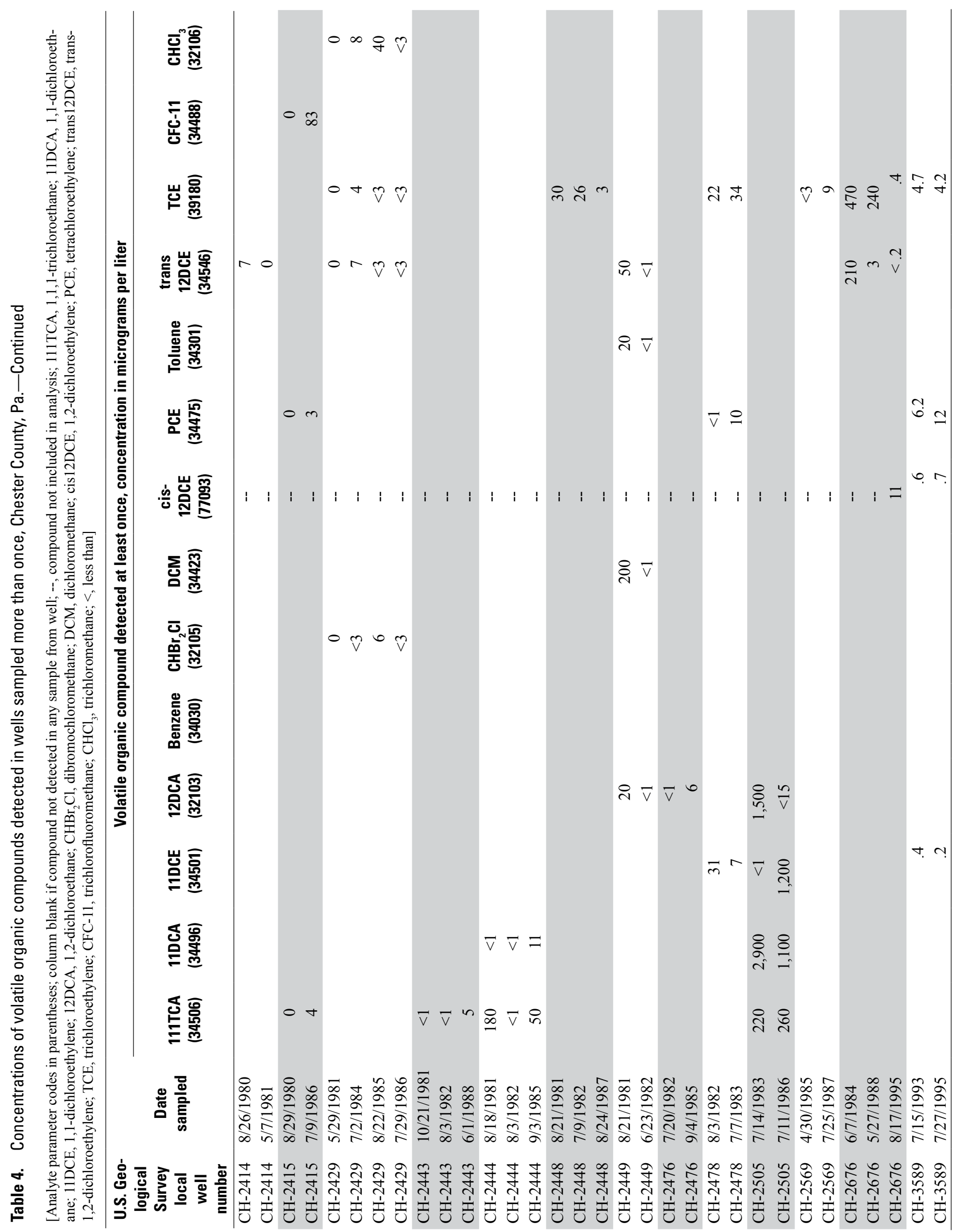




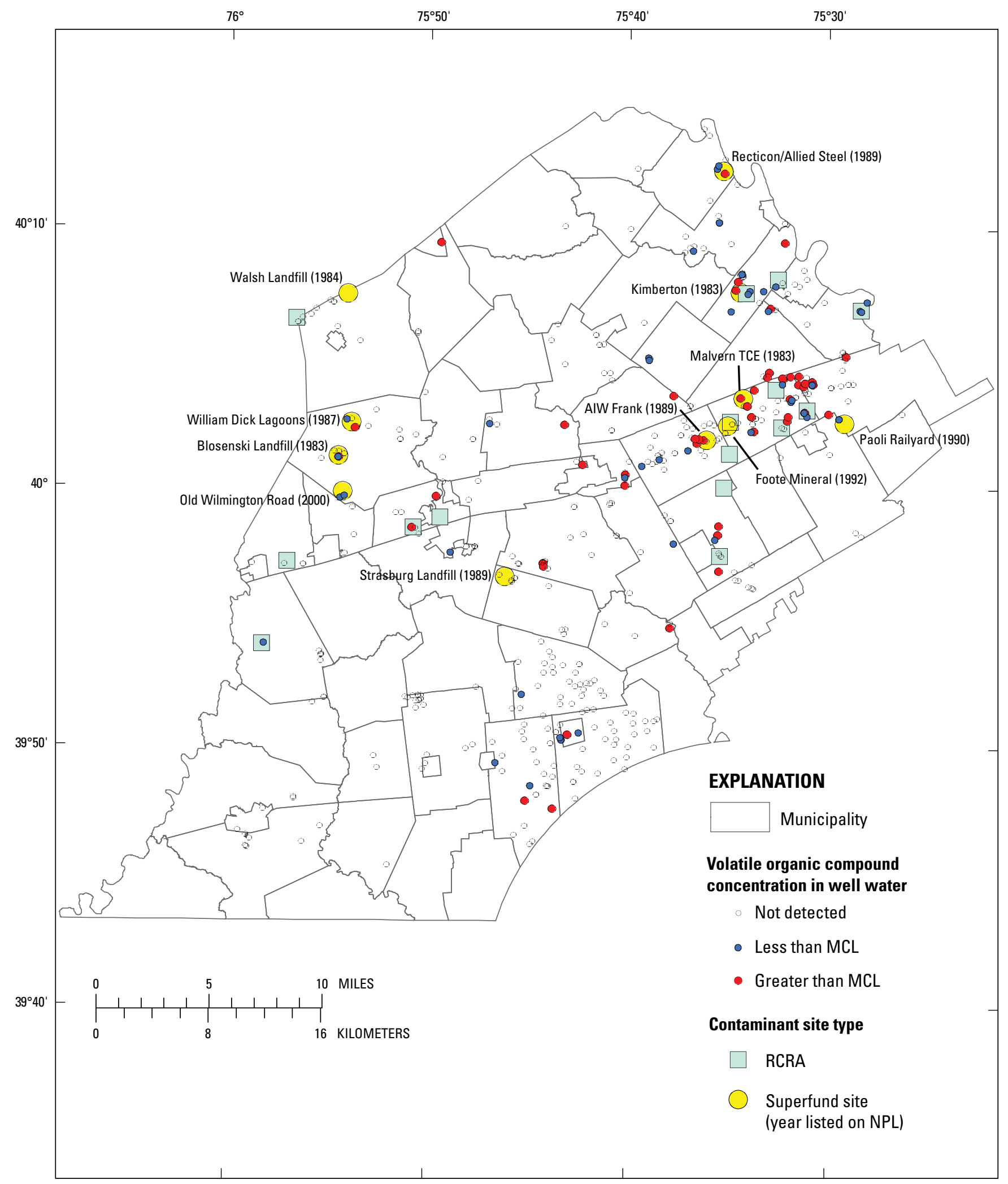

Figure 3. National Priority List (Superfund) and Resource Conservation and Recovery Act (RCRA) sites in Chester County, Pa., and locations of wells sampled through the Chester County groundwater-quality monitoring program that had detections of volatile organic compounds. 
Other contaminants detected in groundwater samples during the first 10 years of the program included base-neutralextractable organic compounds such as napthalene and diethyl phthalate, gross phenols, and elevated concentrations of some metals, such as mercury (Sloto, 1989, 1994) and other inorganic constituents. Most of these constituents, except for gross phenols, were detected infrequently and were only measured near suspected localized contaminant sources. Some phenols occur naturally, and gross phenol analysis includes both natural and anthropogenic compounds. The USEPA has not established a MCL for phenol but lists a HA level of $2 \mathrm{mg} / \mathrm{L}$ for lifetime consumption of phenol (table 3 ). Of the 233 wells sampled for gross phenols, about 18 percent (42 of 233 wells) had concentrations of gross phenol greater than $2 \mu \mathrm{g} / \mathrm{L}$ in at least 1 sample, and about 5 percent ( 11 of 233 wells) had concentrations of gross phenol greater than $5 \mu \mathrm{g} / \mathrm{L}$. Samples from only two wells had more than $25 \mu \mathrm{g} / \mathrm{L}$ gross phenols (up to 30 and $190 \mu \mathrm{g} / \mathrm{L}$ in wells CH-3133 and CH-2419, respectively). No samples had concentrations of gross phenols that exceeded the $\mathrm{HA}$ of $2 \mathrm{mg} / \mathrm{L}$.

Elevated concentrations of the inorganic constituents iron, manganese, and ammonia were measured in groundwater and some stream base-flow samples collected as part of the monitoring program. Elevated concentrations of iron, manganese, and ammonia may be related to reducing conditions (geochemical processes) that release naturally occurring metals and may be associated with the presence of some man-made organic contaminants, although natural processes can also release iron and manganese into groundwater. Generally, iron, manganese, and ammonia have been identified as the primary inorganic contaminants in groundwater associated with landfills (Deutsch, 1998). Ammonia and nitrite are chemically reduced forms of nitrogen that commonly convert to nitrate in oxygenated surface waters (Hem, 1985, p. 126). Concentrations of ammonia and nitrite generally are low (less than 0.05 and $0.01 \mathrm{mg} / \mathrm{L}$ as nitrogen $(\mathrm{N})$, respectively) in groundwater and surface water not affected by human activities in Chester County.

Concentrations of dissolved iron and manganese greater than SMCLs of 300 and $50 \mu \mathrm{g} / \mathrm{L}$, respectively, in some groundwater samples collected near uncontrolled landfills, dumps, and industrial waste disposal areas were the highest measured in groundwater in the county. Concentrations of iron up to $85,000 \mu \mathrm{g} / \mathrm{L}$ were measured in a sample from a well (CH-2473) near a landfill in Honeybrook Township in 1982. Samples from three other wells (CH-2406, CH-3624, and $\mathrm{CH}-2419)$ near landfills had extremely elevated iron concentrations ranging from 22,000 to $80,000 \mu \mathrm{g} / \mathrm{L}$. Samples from these four wells also had high concentrations of manganese that ranged from 2,500 to $22,000 \mu \mathrm{g} / \mathrm{L}$. These manganese concentrations exceed not only the SMCL but the HA of $300 \mu \mathrm{g} / \mathrm{L}$ listed by USEPA to protect human health (table 3). Additional study would be needed to evaluate all causes, some of which may be natural, of elevated concentrations of iron and manganese greater than the SMCLs that commonly occur in groundwater throughout Chester County.
Concentrations of ammonia elevated above background level and up to $4.5 \mathrm{mg} / \mathrm{L}$ as N (well CH-2679) were measured in groundwater near some landfill and dump sites in Chester County. Elevated concentrations of ammonia were measured in groundwater samples collected in 1980-1982, 1984, 1987, and 1989 as part of the Chester County groundwater-quality monitoring program near where Pennsylvania State Route 29 crosses Valley Creek and Little Valley Creek in East Whiteland Township (fig. 4). Ammonia concentrations up to $2.5 \mathrm{mg} / \mathrm{L}$ as $\mathrm{N}$ were measured in groundwater (well $\mathrm{CH}-2411$ ) near Valley Creek and up to $4.4 \mathrm{mg} / \mathrm{L}$ as $\mathrm{N}$ were measured in groundwater (well CH-2448) near Little Valley Creek. Groundwater from well CH-2448 also had elevated nitrite concentrations up to $1.6 \mathrm{mg} / \mathrm{L}$ as $\mathrm{N}$ and other contaminants such as cyanide up to $0.06 \mathrm{mg} / \mathrm{L}$ and TCE up to $30 \mu \mathrm{g} / \mathrm{L}$ that probably were associated with nearby releases of industrial waste.

In 1998, as part of an informal investigation of possible limitations to trout migration and stable in-stream populations, elevated concentrations of ammonia (up to $1.39 \mathrm{mg} / \mathrm{L}$ as N) were measured by USGS (Durlin and Schaffstall, 1999, p. 351) in gaining reaches of Valley Creek near Route 29 near where elevated ammonia had been detected in groundwater (fig. 4). Ammonia concentrations in Little Valley Creek were not determined. The groundwater-quality data support the inference that the elevated ammonia concentrations in the Valley Creek probably are related to discharge of groundwater containing elevated ammonia. An old landfill near Valley Creek and industrial activities near Little Valley Creek are most likely the sources of elevated ammonia in the groundwater and, thus, are the likely sources of ammonia to nearby streams through groundwater discharge in gaining stream reaches.

Other inorganic constituents associated with localized, industrial-waste sources included elevated concentrations of aluminum, nickel, cobalt, and manganese in samples from a well (CH-1074) near a metals processing facility near Atglen. In addition, groundwater samples collected as part of the monitoring program helped identify the transport of lithium and boron from a former metals processing plant in Frazer (now the Foote Mineral Superfund site) in both surface water and groundwater (figs. 3 and 4). The Foote Mineral site is on a groundwater and surface-water divide and is underlain by carbonate rocks. Lithium and boron wastes were disposed of in a former quarry on the eastern part of the site and also to a stream that flows west. Lithium and boron are trace elements that are relatively soluble in water and can be considered conservative tracers in groundwater flow because they are not readily degraded or adsorbed onto aquifer materials. Elevated concentrations of lithium and boron in well-water samples indicated that contaminated groundwater traveled eastward from the site, and stream samples showed that the contaminated groundwater also discharged into gaining reaches of Valley Creek, a tributary that flows east to the Schuylkill River (Sloto, 1987). Lithium and boron discharged in wastewater at the site to the stream flowing west was detected in groundwater west of the site in the West Valley Creek Basin, a tributary 


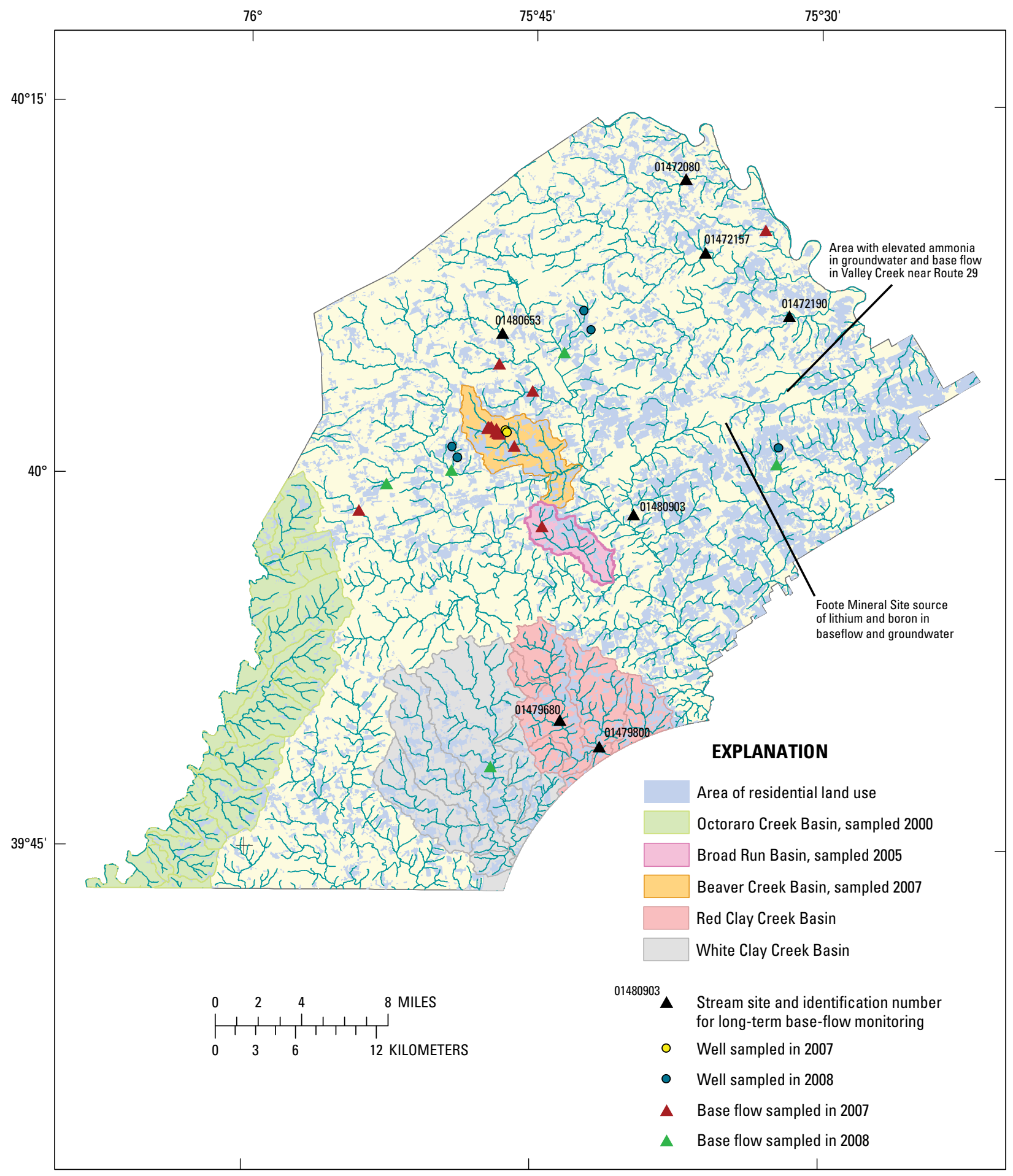

Figure 4. Location of base-flow samples collected as part of the Chester County groundwater-quality monitoring program and selected other areas of base-flow sampling, 1966 through 2008, Chester County, Pa. 
to the Brandywine Creek, probably having entered the groundwater through losing reaches of the stream (Senior and others, 1997). Lithium and boron measurements in groundwater and surface water showed the interconnections between the groundwater and surface-water systems and the pathways of contaminant transport from the source area.

\section{Agricultural Use of Pesticides and Nitrate}

Pesticides (most commonly herbicides and insecticides) and fertilizer applied at the land surface for agricultural and other land uses have the potential to leach into the groundwater system. In Chester County, such constituents have been used in a range of agricultural activities, including the cultivation of row crops, mushrooms, orchards, and nurseries, and non-agricultural activities, including golf courses, vegetation control on transportation rights-of-way, and residential and commercial landscaped areas. The use of these constituents sometimes results in the occurrence of low levels of pesticides or elevated levels of nutrients (especially nitrate) in groundwater.

Concentrations of nitrate greater than the estimated natural background concentration of about $1 \mathrm{mg} / \mathrm{L}$ as $\mathrm{N}$ and all detections of pesticides or herbicides in groundwater are related to human land-use activities in Chester County. Drinking-water standards or MCLs have been established by USEPA for nitrate $(10 \mathrm{mg} / \mathrm{L}$ as $\mathrm{N})$ and nitrite $(1 \mathrm{mg} / \mathrm{L}$ as $\mathrm{N})$ but for only some pesticides (U.S. Environmental Protection Agency, 2009a; table 3).

\section{Countywide Investigations}

Before 1988, few wells in Chester County were sampled for pesticides. From 1988 through 1997, about 95 groundwater samples were collected mostly near agricultural areas such as orchards, mushroom houses and composting operations, and land in row-crop cultivation. A few samples were collected in other areas that may be associated with the use of pesticides and fertilizer, such as transportation rights-of-way and residential areas. Analyses included organochlorine or organophosphate insecticides, herbicides, and the fertilizer nutrients nitrate and phosphate. Many of the wells sampled were in agricultural areas in southern Chester County, especially the Red Clay Creek and White Clay Creek watersheds. These watersheds have diverse types of agriculture, including many mushroom farms and compost operations.

Low concentrations of the herbicides atrazine, 2-chloro4-isopropylamino-6-amino-s-triazine (CIAT), metolachlor, and prometon and the insecticides chlordane, diazinon, DDT, dichlorodiphenyldichloroethylene (DDE), lindane, malathion, methoxychlor, and phorate were detected in groundwater in the Red Clay and White Clay Creek watersheds. Some pesticides were measured at levels that may pose health risks. Lindane concentrations greater than the USEPA MCL of $0.2 \mu \mathrm{g} / \mathrm{L}$ were measured in samples from two wells $(0.34 \mu \mathrm{g} / \mathrm{L}$ in $\mathrm{CH}-4295$ and as high as $25 \mu \mathrm{g} / \mathrm{L}$ in $\mathrm{CH}-4126)$ near a mushroom-growing area. Diazinon concentrations exceeded the USEPA lifetime HA level of $1 \mu \mathrm{g} / \mathrm{L}$ for diazinon in drinking water (table 3$)$ in samples from two wells $(2.6 \mu \mathrm{g} / \mathrm{L}$ in CH-69 and $490 \mu \mathrm{g} / \mathrm{L}$ in CH-4122).

In row-crop areas, the metolachlor concentration of $12.6 \mu \mathrm{g} / \mathrm{L}$ in a well-water sample (CH-2311) was the highest concentration of analyzed herbicides in the county. The USEPA has not established a MCL for metolachlor but lists a lifetime HA level of $700 \mu \mathrm{g} / \mathrm{L}$ for metolachlor in drinking water (U.S. Environmental Protection Agency, 2009a; table 3). Other compounds detected in agricultural areas include atrazine and tebuthiuron. In nursery areas, pesticides detected in well-water samples (CH-30, CH-2461, and $\mathrm{CH}-5222)$ included the herbicides alachlor, CIAT, atrazine, s-ethyl dipropylthiocarbamate (EPTC), metolachlor, prometon, and trifluralin and insecticides carbaryl, carbofuran, dieldrin, lindane, and malathion; the concentration of $2.49 \mu \mathrm{g} / \mathrm{L}$ alachlor in one sample exceeded the MCL of $2 \mu \mathrm{g} / \mathrm{L}$. The herbicides CIAT, simazine, and silvex were detected in well-water samples (CH-2503 and $\mathrm{CH}-5560)$ near orchards. Near a pipeline right-of-way, which is not an agricultural land use, the herbicides ametryn, atraton, atrazine, prometon, prometryn, propazine, simazine, simatone, and simatryn were detected at low concentrations (less than or equal $0.1 \mu \mathrm{g} / \mathrm{L}$ ) in samples from one well (CH-206).

Results of sampling groundwater in the targeted areas showed that nitrate concentrations elevated above natural background (about $1 \mathrm{mg} / \mathrm{L}$ as N) were common, and concentrations as great as $45 \mathrm{mg} / \mathrm{L}$ as $\mathrm{N}$ were measured. About 11 percent of the 543 wells sampled countywide through the groundwater-quality monitoring program had nitrate concentrations that equaled or exceeded the MCL of $10 \mathrm{mg} / \mathrm{L}$ as N, and more of these wells were in the southern part of the county than in the northern part of the county. About 17 percent of the 279 sampled wells in southern Chester County (south of $40^{\circ}$ latitude), where agricultural use is more prevalent than in northern Chester County (fig. 2), had nitrate concentrations equal to or greater than $10 \mathrm{mg} / \mathrm{L}$ as N. Only about 5 percent of the 264 wells in northern Chester County (north of $40^{\circ}$ latitude) had nitrate concentrations equal to or greater than $10 \mathrm{mg} / \mathrm{L}$ as N. Countywide, nitrite concentrations greater than the MCL of $1 \mathrm{mg} / \mathrm{L}$ as $\mathrm{N}$ were infrequent and were measured in samples from only two wells, one of which was in the Red Clay Creek watershed (CH-4730, appendix).

Detections of pesticides at low concentrations were common in many of the targeted areas, but concentrations above drinking-water standards, where established, were infrequent. The common occurrence of low concentrations of pesticides and elevated concentrations of nitrate is related to the effect of various agricultural activities on groundwater quality.

\section{Octoraro Creek Investigation}

To identify potential areas of elevated nitrate concentrations in the Octoraro Creek Basin (fig. 4) in western Chester County where agricultural land use is predominant (fig. 2), samples of groundwater and stream base flow were collected 
in 2000 (fig. 5) as part of the monitoring program. East Branch and mainstem Octoraro Creek form the boundary between Chester and Lancaster County (fig. 5) and are part of the Chesapeake Bay drainage system. The Octoraro Creek supplies a reservoir used for drinking water that has had elevated nitrate concentrations (Chester Water Authority, 2008). During a period of base-flow or low streamflow conditions, when groundwater discharge is the main source of streamflow, base-flow samples were collected near the confluence of seven tributaries with Octoraro Creek. Twenty-one wells within those tributary drainage areas also were sampled. All samples were analyzed for major ions, nutrients (nitrate and phosphate), selected trace elements, and selected pesticides, and results were published in Durlin and Schaffstall (2001b).

Concentrations of nitrate were greater than $7 \mathrm{mg} / \mathrm{L}$ as N in base flow of five of the seven tributaries, including Valley Creek, Leech Run, Muddy Run, and Tweed Creek, and were as high as $9.5 \mathrm{mg} / \mathrm{L}$ as $\mathrm{N}$ in Knight Run. The average nitrate concentrations in well-water samples in each tributary drainage area ranged from 7.1 to $10.8 \mathrm{mg} / \mathrm{L}$ as $\mathrm{N}$ and were similar to base-flow concentrations in most of those areas (fig. 5). The drainage areas with the lowest nitrate concentrations in base flow (3.5 to $4 \mathrm{mg} / \mathrm{L}$ as $\mathrm{N}$ in Black Run and Blackburn Run) also had some of the lowest nitrate concentrations in groundwater. Nitrate concentrations in groundwater ranged from 3.2 to $14 \mathrm{mg} / \mathrm{L}$ as $\mathrm{N}$; 6 of the 21 samples ( 29 percent) had nitrate concentrations greater than the MCL of $10 \mathrm{mg} / \mathrm{L}$ as N and 14 of 21 samples (67 percent) had nitrate concentrations greater than $7 \mathrm{mg} / \mathrm{L}$ as $\mathrm{N}$.

The pesticides atrazine, its degradation product deethyl atrazine, and metolachlor were the most frequently detected of the analyzed pesticides in both groundwater and base-flow samples. In groundwater samples from 21 wells, deethyl atrazine was detected most often ( 20 wells), followed by metolachlor (18 wells), and atrazine (13 wells). Atrazine, deethyl atrazine, and metolachlor were detected in samples from all seven base-flow sites. In groundwater and base-flow samples, the concentrations of deethyl atrazine were higher than its parent atrazine. Concentrations of deethyl atrazine ranged from 0.10 to $0.32 \mu \mathrm{g} / \mathrm{L}$ in base flow and 0.009 to $1.7 \mu \mathrm{g} / \mathrm{L}$ in groundwater. Atrazine concentrations ranged from 0.013 to $0.081 \mu \mathrm{g} / \mathrm{L}$ in base flow and 0.009 to $0.353 \mu \mathrm{g} / \mathrm{L}$ in groundwater. The MCL for atrazine is $3 \mu \mathrm{g} / \mathrm{L}$ in drinking water (table 3 ). Herbicides, such as atrazine, in surface water can harm algae and other lower levels of the food chain in some aquatic environments and have been found to be persistent in tributaries to the Chesapeake Bay (McConnell and others, 2004).

More pesticides were detected in groundwater than in base flow. In addition to atrazine, deethyl atrazine, and metolachlor, 10 other pesticides were detected in groundwater: carbaryl ( 5 wells), simazine ( 4 wells), diazinon ( 3 wells), malathion ( 3 wells), prometon ( 3 wells), dieldrin ( 1 well), EPTC (1 well), tebuthiuron ( 1 well), terbacil ( 1 well), and trifluralin (1 well); three other pesticides were detected in base flow: alachlor (3 sites), tebuthiuron (2 sites), and prometon (1 site). Measured concentrations of these pesticides in the 21 well-water samples did not exceed any established drinkingwater MCL, although not all pesticides analyzed and detected have established MCLs (table 3; U.S. Environmental Protection Agency, 2009a).

Results of sampling in Octoraro Creek tributary subbasins generally show a relation between constituent concentrations in groundwater and surface water (under base-flow conditions); areas with relatively high concentrations of nitrate and pesticides in groundwater also have high concentrations of those constituents in base flow. Concentrations of nitrate and pesticides, however, were more variable in groundwater samples than in base-flow samples within a drainage basin. Because groundwater supplies stream base flow, reducing nitrate loads to the groundwater system would be an important step in lowering the elevated nitrate concentrations in stream base flow and the drinking-water reservoir.

\section{Deicing Salts on Highways and Salt Storage Areas}

Use of salt for deicing roadways has the potential to affect groundwater quality near high-use roads and near salt storage areas. Salts used for deicing include sodium chloride and calcium chloride. These salts are very soluble and readily enter the groundwater system. Other human activities and land uses, such as on-site disposal of wastewater (septic systems), may also contribute chloride salts to groundwater. The estimated natural background concentration of chloride in groundwater in Chester County is about $10 \mathrm{mg} / \mathrm{L}$ or less (Senior and others, 1997). Ludlow and Loper (2004) reported that 50 percent of the 440 well samples analyzed for chloride from 1990 to 2001 contained more than $13 \mathrm{mg} / \mathrm{L}$, indicating that at least half of the wells in the county have chloride concentrations above natural background.

In 1983, 1985, and 1996, samples from a few wells near salt storage areas and highways were analyzed for chloride. Concentrations of chloride as high as $2,100 \mathrm{mg} / \mathrm{L}$ were measured in a sample from a well (CH-2478) at a salt storage area near the Pennsylvania Turnpike. Chloride concentrations greater than the SMCL of $250 \mathrm{mg} / \mathrm{L}$ for drinking water and as high as $350 \mathrm{mg} / \mathrm{L}$ were measured in a domestic well (CH-2574) near the Turnpike. Other similarly elevated chloride concentrations in groundwater near the Pennsylvania Turnpike were reported by Sloto (1987). Chloride concentrations greater than $250 \mathrm{mg} / \mathrm{L}$ are quite elevated in comparison to concentrations in most other well-water samples in the county. Ludlow and Loper (2004) reported that 75 percent of 440 well-water samples in the county had chloride concentrations of $28 \mathrm{mg} / \mathrm{L}$ or less. Water from 44 wells, or about 4 percent of wells in the county with chloride data, had chloride concentrations greater than or equal to $100 \mathrm{mg} / \mathrm{L}$, more than 10 times the natural background concentration.

Where chloride concentrations are elevated, concentrations of sodium and (or) calcium also are likely to be elevated because the most common source of elevated chloride is salt, 


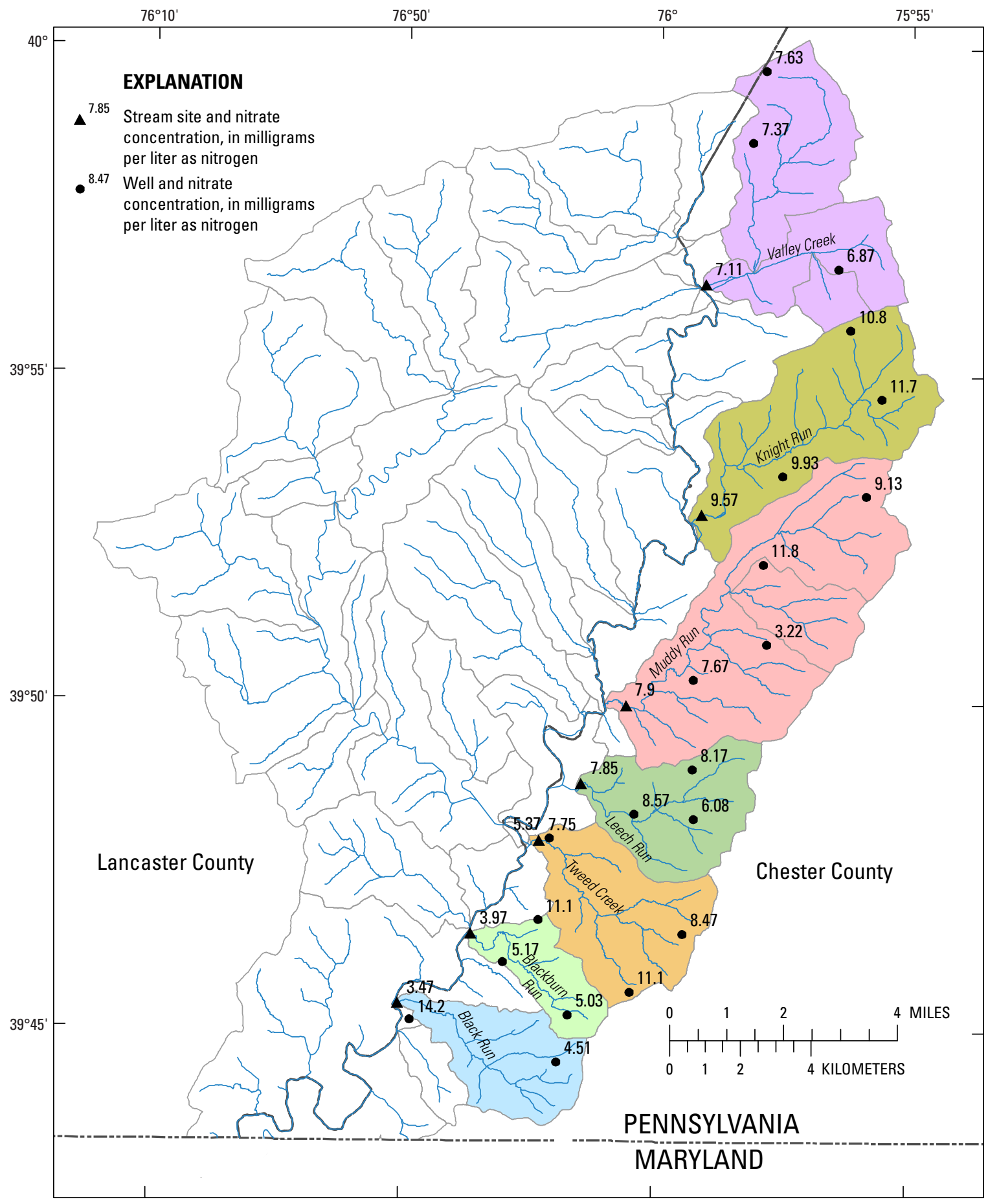

Figure 5. Nitrate concentrations in base-flow samples from 7 tributaries to 0 ctoraro Creek and in groundwater samples from 21 wells in those tributary basins, Chester County, Pa., 2000. Location of Octoraro Creek shown on figure 4. 
a compound generally of either sodium chloride or calcium chloride. When these salts dissolve, both chloride and sodium or calcium are released into the groundwater. The USEPA lists a drinking-water advisory for sodium of $20 \mathrm{mg} / \mathrm{L}$ for individuals on a restricted sodium diet and a range of $30-60 \mathrm{mg} / \mathrm{L}$ threshold for adverse taste effects. Sodium concentrations ranged from 80 to $160 \mathrm{mg} / \mathrm{L}$ in water samples from the two wells (CH-2478 and CH-2574) affected by salt storage and application of deicing salt on the Turnpike.

\section{On-Site Wastewater Disposal}

Various forms of land application of wastewater for disposal are common in Chester County and mainly are used for disposal of residential wastewater but also for disposal of commercial, institutional, or other types of wastewater. Constituents in wastewater that potentially affect groundwater and stream base-flow quality include nutrients, salts, selected trace elements, anthropogenic organic compounds, and bacteria. In many residential settings, individual on-site disposal systems, such as septic systems, are standard for each lot. In other areas, a large community on-site system may serve multiple residences. Large on-site systems may consist of a large septic system, sand mounds, or spray irrigation or drip dispersal of treated effluent. As of 1998, about 40 percent of the population in the county relied on individual on-lot systems (septic systems most common) for wastewater disposal; 46 percent of the population is projected to be using on-lot systems in 2020 (Chester County Water Resources Authority, 2002, p. 74).

Through the Chester County groundwater-quality monitoring program, about 60 groundwater samples were collected from 1987 through 2008 to establish a baseline for future comparison, to assess groundwater quality in sewered and unsewered areas, and to investigate the effects of on-site wastewater disposal on groundwater quality. In 2005, 2007, and 2008, a total of 30 stream base-flow samples also were collected for these purposes, because stream base flow integrates groundwater quality from the contributing area. The stream base-flow samples also can be used to evaluate the relation between groundwater and surface-water quality

Wells sampled to establish baseline water-quality conditions included nine wells sampled in 1988 before the operation of individual on-lot systems or large spray-irrigation systems commenced and five wells sampled in 1996 near new and proposed community on-lot disposal systems (COLDS), such as large sand filter systems (appendix 1). In 2007, two wells and seven stream base-flow sites were sampled to establish baseline water quality before spray irrigation of treated wastewater in a development in the Beaver Creek Basin. Data obtained from resampling these wells could be used to assess the effects of the wastewater disposal on groundwater quality. Selected other wells (CH-75 and CH-410) that have been resampled for a limited number of constituents in areas where spray irrigation disposal of wastewater is used showed increases in chloride concentrations over time. Chloride concentrations increased from $21 \mathrm{mg} / \mathrm{L}$ in 1986 to $33 \mathrm{mg} / \mathrm{L}$ in 2000 in water samples from well CH-75 and from $26 \mathrm{mg} / \mathrm{L}$ in 1986 to $47 \mathrm{mg} / \mathrm{L}$ in 2002 in water samples from well CH-410.

To assess groundwater quality in areas with on-site residential wastewater disposal, nine wells on relatively small lots (about 1 acre) in residential land use since the 1970s were sampled in 1995. Analyses were performed for major ions, nutrients, selected trace elements, and VOCs. The groundwater-quality results, as partially summarized in table 5 , show that concentrations of nitrate, chloride, and boron commonly were moderately elevated above estimated natural background concentrations of these constituents in groundwater in Chester County. Nitrate concentrations (3.1 to $7.9 \mathrm{mg} / \mathrm{L}$ as $\mathrm{N}$ ) were moderately elevated above the natural background concentration of about $1 \mathrm{mg} / \mathrm{L}$ as $\mathrm{N}$, chloride concentrations $(7.3$ to $64 \mathrm{mg} / \mathrm{L})$ were near or greater than the natural background concentration of $10 \mathrm{mg} / \mathrm{L}$, and boron concentrations (less than 10 to $120 \mathrm{mg} / \mathrm{L}$ ) were near or greater than the natural background concentration of about 10 to $20 \mu \mathrm{g} / \mathrm{L}$. In addition, low concentrations of a few VOCs were measured in samples from six of the nine wells. These man-made compounds (VOCs) were likely introduced into groundwater through on-site wastewater disposal. The maximum concentrations of detected VOCs were $0.5 \mu \mathrm{g} / \mathrm{L}$ chloroform; $5.32 \mu \mathrm{g} / \mathrm{L}$ trichloroethane; $1 \mu \mathrm{g} / \mathrm{L}$ chlorofluorocarbon; 1,1,2-trichloro1,2,2-trifluoroethane (CFC-113); $1.7 \mu \mathrm{g} / \mathrm{L}$ 1,1-dichloroethane; $1.8 \mu \mathrm{g} / \mathrm{L}$ 1,1-dichloroethene; $0.5 \mu \mathrm{g} / \mathrm{L}$ methyl tert-buytl ether (MTBE); and $0.4 \mu \mathrm{g} / \mathrm{L}$ trichloroethylene.

Data collected in 2005 show differences in the quality of groundwater and base flow in residential areas with on-site wastewater and in residential areas with sewers. In 2005, groundwater and stream base-flow samples were collected in headwater areas of Broad Run (fig. 4) with various land uses, including residential areas with on-site wastewater disposal and sewered residential areas (Senior and Cinotto, 2007). Concentrations of nitrate and boron generally were higher in groundwater and stream base flow in samples from residential areas with on-site wastewater disposal than in samples from residential areas that are sewered. These findings are consistent with stream base-flow samples collected for other studies in Chester County (Senior and others, 1997; Senior and Koerkle, 2003) and with other data collected through the Chester County groundwater-quality monitoring program.

Selected anthropogenic organic compounds found in wastewater, such as pharmaceuticals, detergents, fragrances, and solvents, in addition to nutrients and other inorganic constituents were analyzed for in groundwater and baseflow samples collected in 2000, 2002, 2005, 2007, and 2008. Results for 2000, 2002, and 2005 are described in Senior and Cinotto (2007) and indicate that concentrations of nitrate, chloride, and boron in groundwater and stream base flow may be elevated in areas that receive on-site wastewater disposal either by spray irrigation, drip dispersal, or septic systems. Anthropogenic organic wastewater compounds were detected at low concentrations in groundwater and base-flow samples. Results for 2008 samples are briefly described in the following paragraphs on groundwater and base-flow quality in the five 
Table 5. Concentrations of chloride, boron, nitrate, and orthophosphate detected in samples from nine wells in residential areas with on-site wastewater disposal in use since the 1970s, Chester County, Pa.

[mg/L, milligrams per liter; $\mu \mathrm{g} / \mathrm{L}$, micrograms per liter; $\mathrm{N}$, nitrogen; $\mathrm{P}$, phosphorus; $<$, less than]

\begin{tabular}{|c|c|c|c|c|c|}
\hline $\begin{array}{c}\text { U.S. Geological } \\
\text { Survey local well } \\
\text { number }\end{array}$ & Date sampled & $\begin{array}{l}\text { Chloride } \\
\text { (mg/L) }\end{array}$ & $\begin{array}{l}\text { Boron } \\
(\mu \mathrm{g} / \mathrm{L})\end{array}$ & $\begin{array}{c}\text { Nitrate } \\
\text { (mg/L as } \mathrm{N})\end{array}$ & $\begin{array}{c}\text { Orthophosphate } \\
\text { (mg/L as } \mathrm{P})\end{array}$ \\
\hline CH-4339 & 9/21/1995 & 9.6 & $<10$ & 5.5 & 0.04 \\
\hline CH-4539 & $9 / 21 / 1995$ & 10.0 & 10 & 3.9 & .04 \\
\hline CH-5238 & $9 / 28 / 1995$ & 9.5 & 20 & 5.6 & .03 \\
\hline CH-5259 & $9 / 20 / 1995$ & 64.0 & 30 & 6.4 & .02 \\
\hline CH-5261 & $9 / 26 / 1995$ & 7.3 & $<10$ & 7.9 & $<.01$ \\
\hline CH-5269 & $10 / 11 / 1995$ & 17.0 & 40 & 6.0 & .07 \\
\hline CH-5270 & $10 / 11 / 1995$ & 9.6 & $<10$ & 4.4 & .05 \\
\hline CH-5272 & $10 / 12 / 1995$ & 22.0 & 10 & 4.3 & .05 \\
\hline
\end{tabular}

areas where land use is predominantly residential and onsite wastewater disposal is prevalent. Anthropogenic organic wastewater compounds also were detected in groundwater and base-flow samples in an assessment of an area near the dam on Beaver Creek in 2007, which is discussed later in this report in the section on Other Localized Sources and Targeted Areas.

In 2008, groundwater and base-flow samples were collected in five headwater areas that were predominantly residential with on-site disposal of wastewater to assess the effects of wastewater disposal on water quality (fig. 4). One base-flow sample was collected in each of the headwater areas. Two groundwater samples were collected in each of two headwater areas and one groundwater sample was collected in a third. Samples were analyzed for major ions, nutrients, selected trace elements, and selected organic wastewater compounds. Results, except for one groundwater sample collected in October 2008, were published online (U.S. Geological Survey, 2009). Results for selected analyses that are wastewater indicators are listed in table 6.

Nitrate concentrations ranged from 1.86 to $6.57 \mathrm{mg} / \mathrm{L}$ as $\mathrm{N}$ in groundwater samples and from 1.81 to $3.30 \mathrm{mg} / \mathrm{L}$ as $\mathrm{N}$ in stream base-flow samples. These observed nitrate concentrations are elevated above the estimated natural background of $1 \mathrm{mg} / \mathrm{L}$, indicating anthropogenic sources of nitrate have affected groundwater and base-flow quality. Other constituents that indicate possible effects of on-site wastewater disposal include concentrations of chloride greater than natural background of $10 \mathrm{mg} / \mathrm{L}$ or less and the detection of organic wastewater compounds in groundwater and base-flow samples.

\section{Other Localized Land Uses and Targeted Areas}

In addition to the sources listed above, groundwater samples were collected near other localized land uses associated with the use of various chemical compounds and con- stituents and in areas of interest to CCHD and CCWRA where groundwater quality was unknown.

\section{Cemeteries}

From 1990 through 1997, 10 wells near cemeteries were sampled to determine if embalming compounds leached into groundwater. Samples were analyzed for formaldehyde and selected trace metals, including arsenic and lead. Formaldehyde has been used for embalming since the 19th century. Arsenic was used in embalming fluids from the mid 1860s to about 1910 when this use of arsenic was banned. Elevated concentrations of arsenic, cobalt, copper, iron, lead, and zinc in soils were reported in a study of a cemetery in operation since the mid 19th century in Ohio and may have been introduced by leaching embalming fluids and breakdown of metal components of caskets (Spongberg and Becks, 2000).

The limited data collected as part of the groundwaterquality monitoring program in Chester County show that cemeteries may affect groundwater quality nearby with contaminants such as formaldehyde present in concentrations greater than HA levels. Formaldehyde was detected in 4 of the 10 well-water samples collected through the program; concentrations ranged from 0.09 to $1.10 \mathrm{mg} / \mathrm{L}$ (equivalent of 90 to $1,100 \mu \mathrm{g} / \mathrm{L})$ (table 7$)$. The minimum reporting level for the formaldehyde analyses ranged from 0.01 to $0.10 \mathrm{mg} / \mathrm{L}$. Currently, no drinking-water standard has been established for formaldehyde, although the compound is on the draft Contaminant Candidate List 3 (CCL3) released by USEPA in February 2008 and USEPA has listed a HA level of $1 \mathrm{mg} / \mathrm{L}$ for formaldehyde in drinking water (table 3 ).

Elevated concentrations of trace metals were not detected in most of the eight samples with metals analyses. These results suggest that elevated concentrations of trace metals in groundwater in Chester County probably are not associated with cemeteries. The highest concentrations of trace metals measured were $3 \mu \mathrm{g} / \mathrm{L}$ arsenic, $5 \mu \mathrm{g} / \mathrm{L}$ chromium, $180 \mu \mathrm{g} / \mathrm{L}$ 


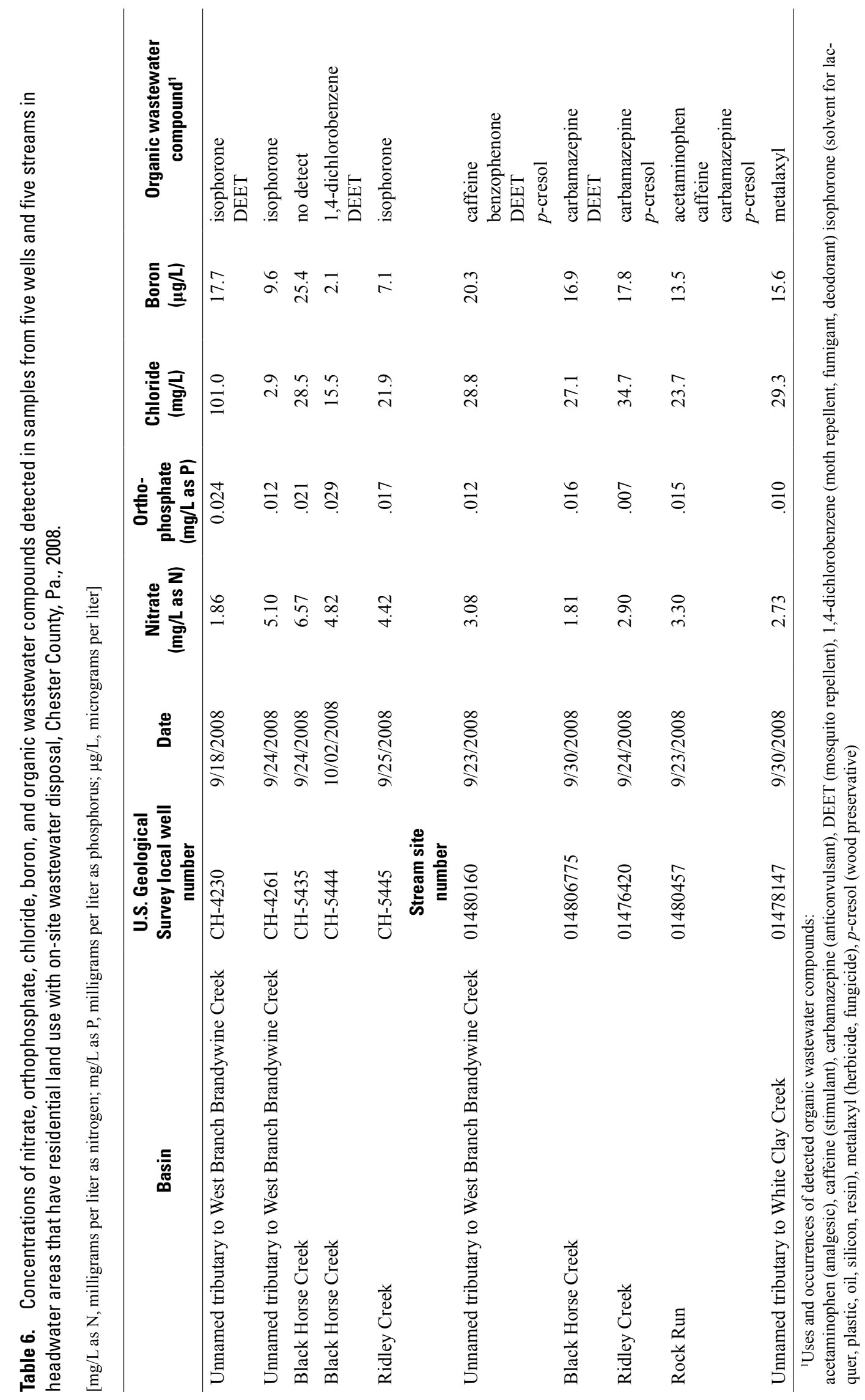


Table 7. Concentrations of formaldehyde and lead and $\mathrm{pH}$ detected in samples from 10 wells near cemeteries, Chester County, Pa., 1990 through 1997.

[mg/L, milligrams per liter; $\mu \mathrm{g} / \mathrm{L}$, micrograms per liter; <, less than; --, no data]

\begin{tabular}{llccc}
\hline $\begin{array}{c}\text { U.S. Geological Survey } \\
\text { local well number }\end{array}$ & \multicolumn{1}{c}{ Date of sample } & $\begin{array}{c}\text { Formaldehyde } \\
(\mathbf{m g} / \mathbf{L})\end{array}$ & $\begin{array}{c}\text { Lead } \\
(\boldsymbol{\mu g} / \mathbf{L})\end{array}$ & $\begin{array}{c}\text { Field } \\
\mathbf{p H}\end{array}$ \\
\hline CH-4023 & $9 / 4 / 1990$ & 1.10 & 1 & 5.7 \\
CH-3561 & $8 / 14 / 1991$ & $<.05$ & -- & 6.6 \\
CH-4125 & $8 / 7 / 1991$ & -.01 & - & 6.3 \\
CH-3184 & $8 / 28 / 1996$ & -22 & $<1$ & 7.3 \\
CH-5480 & $9 / 11 / 1996$ & .05 & $<1$ & 6.6 \\
CH-432 & $9 / 3 / 1997$ & $<.05$ & 10 & 5.8 \\
CH-5553 & $8 / 12 / 1997$ & .10 & $<10$ & 6.2 \\
CH-5557 & $8 / 25 / 1997$ & $<.05$ & 10 & 5.0 \\
CH-5558 & $8 / 26 / 1997$ & $<.05$ & 20 & 4.9 \\
CH-5562 & $9 / 8 / 1997$ & $<1$ & 6.5 \\
\hline
\end{tabular}

copper, $20 \mu \mathrm{g} / \mathrm{L}$ lead, $0.5 \mu \mathrm{g} / \mathrm{L}$ mercury, $13.2 \mu \mathrm{g} / \mathrm{L}$ nickel, $1 \mu \mathrm{g} / \mathrm{L}$ silver, and $35 \mu \mathrm{g} / \mathrm{L}$ zinc. Beryllium, cadmium, cobalt, lithium, and vanadium were not detected, and concentrations of most trace metals analyzed were less than the laboratory minimum reporting level that ranged from $0.1 \mu \mathrm{g} / \mathrm{L}$ to less than $10 \mu \mathrm{g} / \mathrm{L}$ depending on the analysis. Concentrations of dissolved iron were higher than the SMCL of $300 \mu \mathrm{g} / \mathrm{L}$ in only one sample $(5,840 \mu \mathrm{g} / \mathrm{L})$, and manganese concentrations were all less than the SMCL of $50 \mu \mathrm{g} / \mathrm{L}$. The concentration of dissolved lead of $20 \mu \mathrm{g} / \mathrm{L}$ in one well-water sample exceeded the action level of $15 \mu \mathrm{g} / \mathrm{L}$ established by USEPA (table 3 ) for lead in drinking water. However, all samples that had detectable concentrations of lead ( 1 to $20 \mu \mathrm{g} / \mathrm{L}$ ) were relatively acidic, having $\mathrm{pH}$ values of 5.8 or less. These results suggest that lead is more soluble in acidic groundwater. The source of lead in the groundwater samples is unknown.

\section{County Parks and Other County-Owned Land}

Data on groundwater quality in county-owned parks and other land were collected through the groundwaterquality monitoring program from 1991 through 1996 to identify possible water-quality problems on county-owned land and to obtain baseline information for areas that would become county-owned land. Wells were sampled in Warwick, Hibernia, and Nottingham Parks; in the area to be flooded by Hibernia dam; at county-owned desilting basins near the Schuylkill River; and on former Church Farm School property (fig. 2). The latter included 713 acres that were cooperatively purchased in 1994 by West Whiteland Township and Chester County to become public open space as Exton Park and in part to be used for disposal of wastewater by spray irrigation. Samples were analyzed for major ions, nutrients, selected trace metals, radon-222, and some anthropogenic organic compounds. Except for the two samples from Nottingham Park, analyses also included selected pesticides and VOCs.
Results revealed a few water-quality concerns. Samples from two wells at the former Church Farm School property sampled in 1991 had elevated nitrate (11 and $13 \mathrm{mg} / \mathrm{L}$ as $\mathrm{N}$ ) above the drinking-water MCL of $10 \mathrm{mg} / \mathrm{L}$ as $\mathrm{N}$ and one sample had low concentrations of pesticides (atrazine and metolachlor). Other USGS data on groundwater quality at Church Farm School are reported by Senior and others (1997). Low concentrations of some pesticides (CIAT, simazine) and (or) MTBE were measured in samples collected in 1994 from two wells (CH-5088 and $\mathrm{CH}-5089)$ now decommissioned and flooded by Hibernia dam. The sample from one well (CH-5226) at Nottingham Park had an elevated $\mathrm{pH}$ of 9.5 , which is related to the underlying serpentine rocks. No water-quality problems except slightly acidic $\mathrm{pH}$ values were identified with samples collected from the wells at Warwick or Hibernia County Parks (CH-2317 and CH-5087).

Samples were collected in 1993-95 from five wells near desilting basins owned by the county along the banks of the Schuylkill River that forms the northern border of Chester County. These desilting basins were created in the late 1940s to hold coal silt and other sediments dredged from the Schuylkill River. The dredged materials are known to contain trace metals and anthropogenic organic compounds such as DDT and PCB (Stamer and others, 1985). Contaminants associated with sediments in the desilting basins potentially could leach into nearby groundwater.

Groundwater samples collected from the five wells near the desilting basins showed no inorganic water-quality problems. Concentrations of trace metals were not elevated in the samples, although one sample had $19 \mu \mathrm{g} / \mathrm{L}$ molybdenum, which is above the median for Chester County. The molybdenum probably is naturally occurring and related to underlying geology as indicated by data collected in similar Triassic rocks (Senior and Sloto, 2006). Molybdenum has no MCL but is listed by USEPA as a contaminant of concern on the draft CCL3 and has a HA level of $40 \mu \mathrm{g} / \mathrm{L}$ (table 3 ). Four of the 
five samples also were analyzed for VOCs. A low concentration $(1.8 \mu \mathrm{g} / \mathrm{L})$ of PCE was detected in a water sample from a well (CH-4502) near the Recticon/Allied Steel Superfund site, which is a known source of VOC contamination in groundwater (U.S. Environmental Protection Agency, 2009c). Low concentrations (less than $2 \mu \mathrm{g} / \mathrm{L}$ ) of several VOCs $(1,1,1-\mathrm{TCA}$, styrene, toluene, TCE) were detected in an industrial well (CH-4801) near a desilting basin and probably are related to industrial activities in the area.

\section{General Land-Use Assessments}

In 1998, to support a study on modeling streamflow and water quality in the Christina River Basin, four wells (appendix 1) were sampled to provide data on groundwater quality in four different land-use areas. Land uses targeted for sampling included row-crop agriculture (well CH-2311), residential with on-site wastewater disposal (well CH-5160), sewered residential (well CH-4828), and forested (well CH-4817). Nitrate concentrations ranged from 0.15 to $11.6 \mathrm{mg} / \mathrm{L}$ as $\mathrm{N}$ and were lowest in the sample from the forested area and highest in the sample from the agricultural area. In addition to a nitrate concentration exceeding the MCL of $10 \mathrm{mg} / \mathrm{L}$ as $\mathrm{N}$, the sample from the well in the agricultural area also contained the herbicides cyanazine $(0.12 \mu \mathrm{g} / \mathrm{L})$ and metolachlor $(12 \mu \mathrm{g} / \mathrm{L})$. The nitrate concentration was higher in the sample from the residential area with on-site wastewater disposal $(4.51 \mathrm{mg} / \mathrm{L}$ as $\mathrm{N}$ ) than in the sample from the sewered residential area $(2.79 \mathrm{mg} / \mathrm{L}$ as $\mathrm{N})$. The sample from the residential area with on-site wastewater disposal had the highest chloride concentration $(24.4 \mathrm{mg} / \mathrm{L})$ and the only detection of boron $(28 \mu \mathrm{g} / \mathrm{L})$ compared to samples from the three other land-use areas. MTBE (a fuel additive) was detected at low levels $(0.2 \mu \mathrm{g} / \mathrm{L}$ or less) in samples from the agricultural area and the residential area with on-site wastewater disposal.

In 2001, 21 wells (appendix 1) were sampled in parts of the county where little to no groundwater-quality data were available and no localized contaminant sources were known. These data were collected to provide a general assessment of water quality where unknown and to provide broader spatial assessments throughout the county. Water-quality problems identified in 2001 included elevated concentrations of nitrate above the MCL of $10 \mathrm{mg} / \mathrm{L}$ as $\mathrm{N}$ in samples from two wells $(10.6 \mathrm{mg} / \mathrm{L}$ as $\mathrm{N}$ in well $\mathrm{CH}-1283$ and $13.4 \mathrm{mg} / \mathrm{L}$ as $\mathrm{N}$ in well CH-5998) and detection of low levels of pesticides in water from seven wells (CH-1283, CH-1730, CH-5998, CH-6399, CH-6400, CH-6402, and CH-6404). More than one pesticide was detected in each of these seven wells, but concentrations did not exceed any established MCL. Detected pesticides included alachlor, atrazine, deethyl atrazine, carbofuran, metolachlor, prometon, 2,4-D, and DDE. Metolachlor and atrazine were the most commonly detected pesticides, found in six and five of the well samples, respectively, at concentrations up to $0.054 \mu \mathrm{g} / \mathrm{L}$ for metolachlor and $0.076 \mu \mathrm{g} / \mathrm{L}$ for atrazine. Carbofuran and deethyl atrazine were detected in samples from two wells at concentrations up to 0.072 and
$0.266 \mu \mathrm{g} / \mathrm{L}$, respectively. Alachlor was detected once at a concentration of $0.719 \mu \mathrm{g} / \mathrm{L}$. 2,4-D, DDE, and prometon also were detected once at concentrations less than $0.005 \mu \mathrm{g} / \mathrm{L}$. The water-quality problems of elevated nitrate concentrations and low pesticide concentrations are most common in agricultural areas of the county.

\section{Pre-Development Groundwater and Base-Flow Quality in Beaver Creek Basin in 2007}

In 2007, groundwater, stream base-flow, and reservoir water and sediment samples were collected to establish water-quality conditions in an area in the Beaver Creek Basin (fig. 4) that was to undergo conversion from agricultural (primarily corn and other row crop) to residential and golf course land use with planned disposal of treated residential wastewater to include spray irrigation onto golf course lands near the Beaver Creek sediment pool. Samples were analyzed for major ions, nutrients, and selected trace elements and organic wastewater compounds. These data can provide a baseline for comparison of future sampling results to indicate changes in water quality that may occur because of the conversion of land uses. Samples were collected before major land disturbance and construction activities had commenced for the development project.

The samples collected in 2007 indicated that elevated concentrations of nitrate were present in base flow (up to $21.9 \mathrm{mg} / \mathrm{L}$ as N) and groundwater (up to $7.3 \mathrm{mg} / \mathrm{L}$ as N) (table 8; U.S. Geological Survey, 2008). Some pesticides (metolachlor and prometon) were detected in mainstem and tributary base flow upstream of and within the sediment pool and in Beaver Creek downstream of the dam. Other compounds commonly present in wastewater were detected in the sediment pool and its sediments (site 01480744) and in base flow (sites 014807447, 01480745, and 01480750) downstream of the dam. More organic wastewater compounds were detected in sediment samples than in the water samples and concentrations were higher in sediment than stream samples (U.S. Geological Survey, 2008).

Base-flow samples from six sites on other streams in Chester County (fig. 4) also were analyzed for major ions, nutrients, and selected trace elements and organic wastewater compounds to serve as a reference for the Beaver Creek watershed samples. Land uses in the drainage areas of these six stream sites are primarily agricultural and residential with on-site wastewater disposal. Samples collected at the reference sites through time could be used to compare with Beaver Creek samples and to help assess non-land-use effects, such as atmospheric inputs, on water quality. Nitrate concentrations ranged from 2.0 to $4.6 \mathrm{mg} / \mathrm{L}$ as $\mathrm{N}$, and several wastewater compounds were detected at low concentrations in the baseflow samples (table 8; also see appendix 1, year 2007, for site list) (U.S. Geological Survey, 2008), indicating that base-flow quality is affected by application of nutrients and wastewater to land in the drainage areas. 


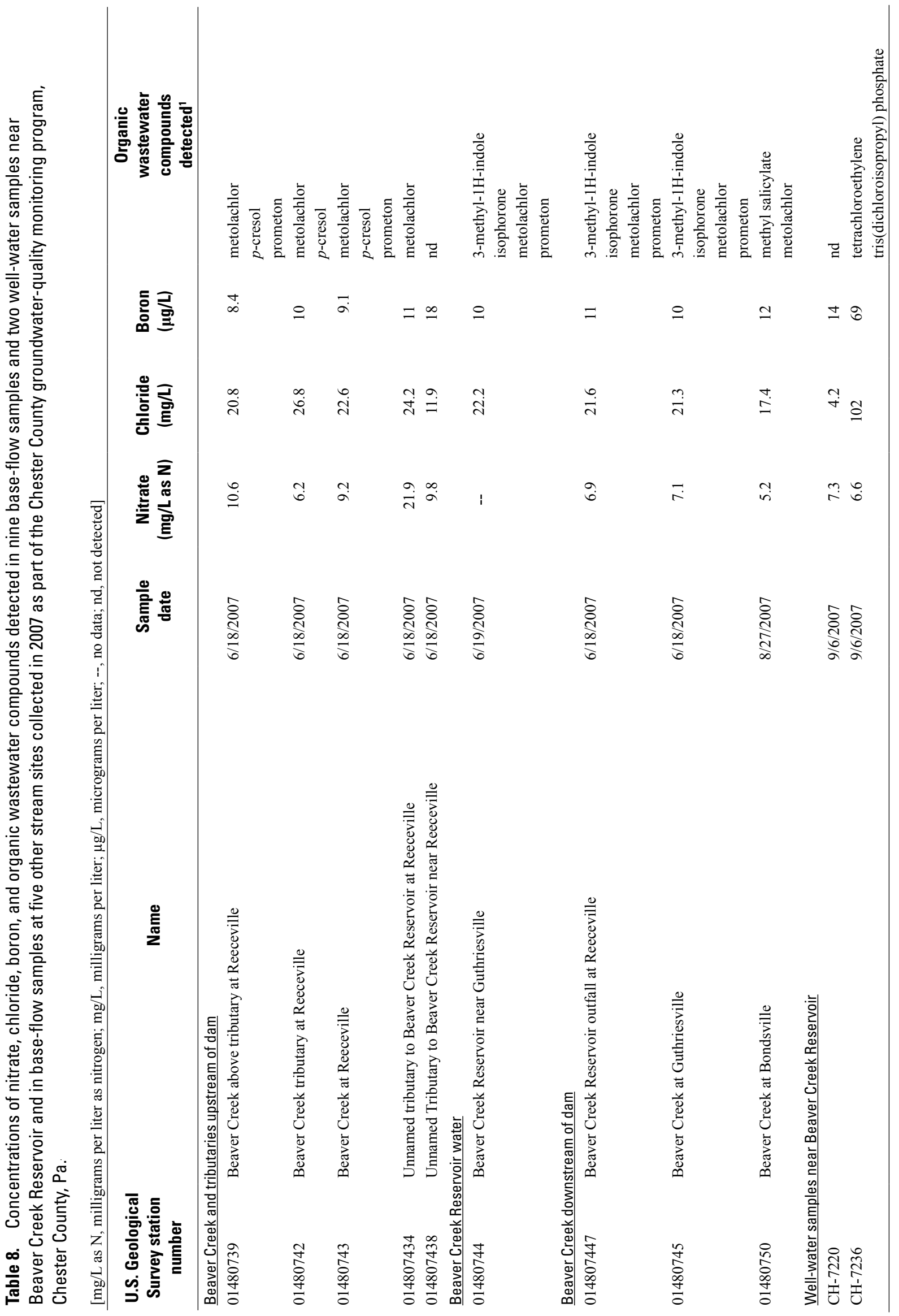




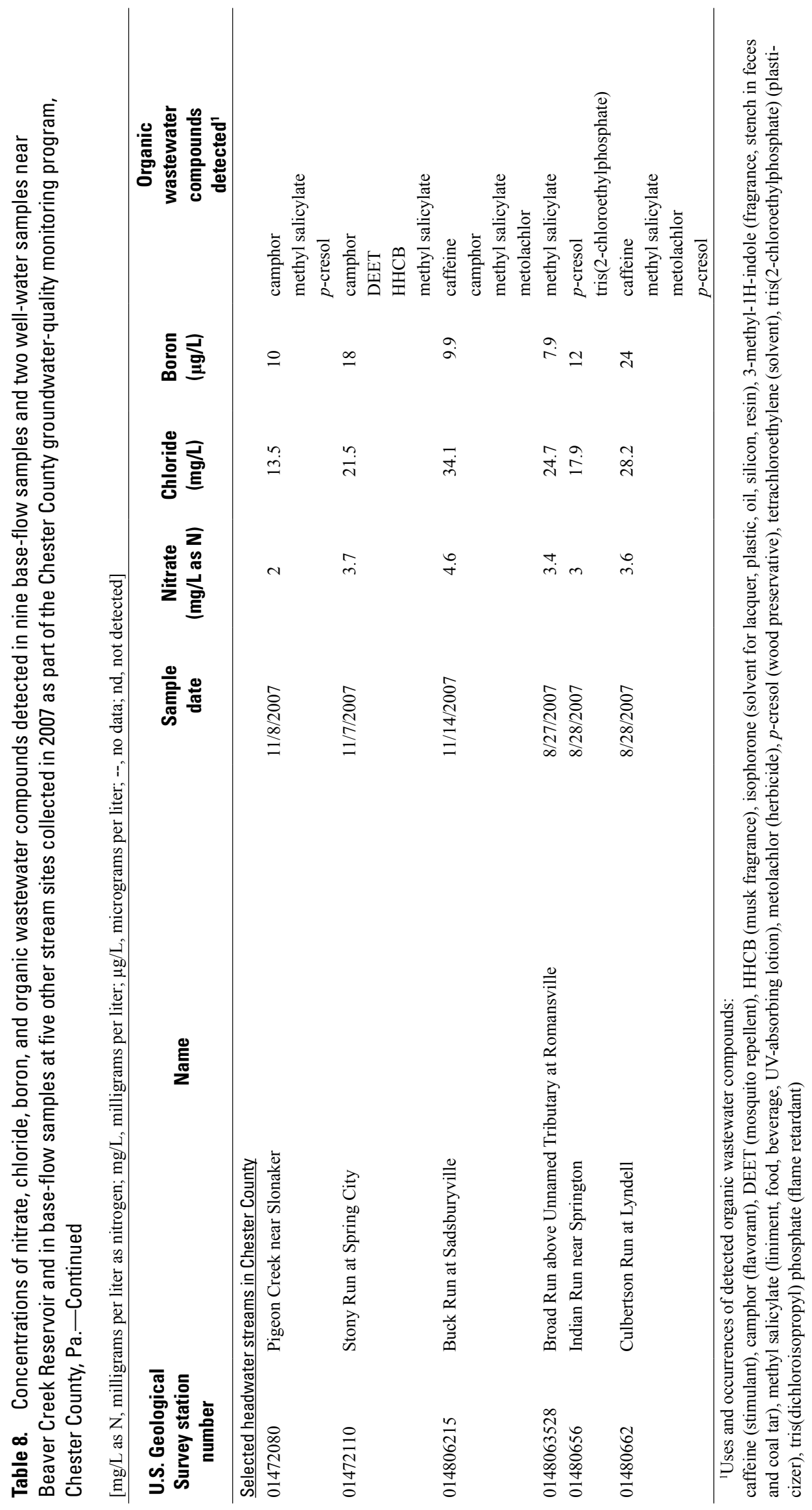




\section{Chloride as Indic ator of Land-Use Change}

Widespread introduction of chloride from human activities to land surface or near surface includes use of deicing salts on roads and on-site wastewater disposal in Chester County. Increases in chloride application may be anticipated in areas of the county that undergo residential development and urbanization because of increases in road density and the number of on-site wastewater disposal systems. Chloride also may be applied to the land surface to a lesser extent in other land uses, such as agriculture (Mullaney and others, 2009). Chloride applied at or near the land surface readily dissolves and infiltrates through soils to the groundwater system. Once dissolved, chloride is a relatively conservative solute and is not degraded, adsorbed, or precipitated out of solution. Chloride as a tracer travels with groundwater flow.

As noted earlier, groundwater quality can change through time because of changes in land use and associated constituent sources at the land surface as well as other factors. Information about the extent of changes in chloride concentrations in groundwater is available for some wells in Chester County that have been sampled more than once. In addition, data on long-term changes in chloride concentrations in base flow in Chester County are available from a separate monitoring program (Reif, 2002a).

\section{Well-Water Samples}

Chloride concentration data are available for 65 wells that have been sampled more than once in the county through the monitoring program. Forty-eight of the 65 wells were sampled at least 5 years apart. Comparison of the earliest and latest samples from the 48 wells indicates that chloride concentrations increased through time in about 80 percent of the wells sampled. Generally, the range and median increases in chloride concentrations are greatest for samples collected more than 20 years apart and least for samples collected less than 10 years apart. The median increase in relative (and actual) chloride concentration was 238 percent $(31 \mathrm{mg} / \mathrm{L})$ for 17 wells sampled $20-40$ years apart, 55 percent $(12 \mathrm{mg} / \mathrm{L})$ for 23 wells sampled 10-19 years apart, and 20 percent $(4.5 \mathrm{mg} / \mathrm{L})$ for 14 wells sampled 5-9 years apart. For the 17 wells sampled less than 5 years apart, the median change in relative (and actual) chloride concentration is about 6 percent $(1 \mathrm{mg} / \mathrm{L})$, indicating little change over that period. These reported differences in chloride concentrations are for samples typically collected in late summer or early fall and are not expected to be affected to a major extent by seasonal changes in recharge and chloride loading rates.

To determine long-term trends, however, determination of seasonal fluctuations would be important as would more frequent sampling of a set of wells over an extended period (years). In a separate study, Sloto (1994) sampled six wells monthly for about a year to measure seasonal changes in concentrations of major ions and reported that the fluctuations in chloride concentrations over the year ranged from 19 to 180 percent, with a median of 25 percent. The range of monthly or seasonal fluctuations over a year is needed to allow comparison of short-term (month) to long-term (multipleyear) changes and to determine long-term trends. Sloto (1994) also reported for comparison of 1946-76 to 1982-83 data that median long-term increases in chloride concentrations in groundwater were greater in sewered areas than in non-sewered areas, which may be related to the greater use of road salt in the usually more densely populated sewered areas.

Thus, increases in chloride concentration in groundwater probably reflect urbanizing trends in the county. Increases in chloride are likely to be accompanied by increases in other ions from salt sources, such as sodium and calcium, and perhaps by other constituents associated with urbanization.

\section{Stream Base-Flow Samples}

Although the Chester County groundwater-quality monitoring program currently has no formal temporal component, some understanding of selected long-term trends in groundwater quality may be gained from evaluation of relatively conservative constituents, such as chloride, and to a lesser extent, nitrate in base-flow samples collected annually in the autumn through the Chester County biological and chemical network (Reif, 2002a). These base-flow samples, which are analyzed for major ions and nutrients, integrate the quality of groundwater that discharges to the stream above the sampling site. The base-flow data generally reflect the multiple land uses and geology in the drainage area and cannot be used to determine local changes in groundwater quality that might be associated with local land-use change.

Trends have been observed in base-flow inorganic quality and inferred groundwater quality for streams that have no point discharges. Statistical analysis indicates that chloride concentrations in base flow increased from 1971 to 1993 in the urbanizing West Valley Creek Basin (Senior and others, 1997) and from 1970 to 1996 in the East and West Branches of Red Clay Creek (Senior, 1996) (fig. 4). The data from 1996 to 2007 show that the increases in chloride concentrations in base flow at East Branch Red Clay Creek appear to have continued (fig. 6A). Similar trends of increasing chloride concentrations in base flow from 1969 to 2007 are indicated by annual data collected in some other streams without point discharges in Chester County (fig. 6B-E). Reif (2002a) noted increases in base-flow specific conductance, a measurement that indicates the amount of dissolved constituents including chloride, from 1981 to 1997 at 36 of 43 stream sites. Nitrate concentrations in base flow increased at several sites without point discharges during that time period and in the Valley Creek tributary to the Octoraro Creek increased from less than $4 \mathrm{mg} / \mathrm{L}$ as $\mathrm{N}$ in 1981 to more than $9 \mathrm{mg} / \mathrm{L}$ as $\mathrm{N}$ in 1997 (Reif, 2002b). The increasing trends of chloride and nitrate in streams without point discharges reflect increasing loads of these constituents from land uses. As land becomes more intensively developed (including urban and agricultural uses), the effects of associated constituents are likely to result in changes to groundwater and base-flow quality. 

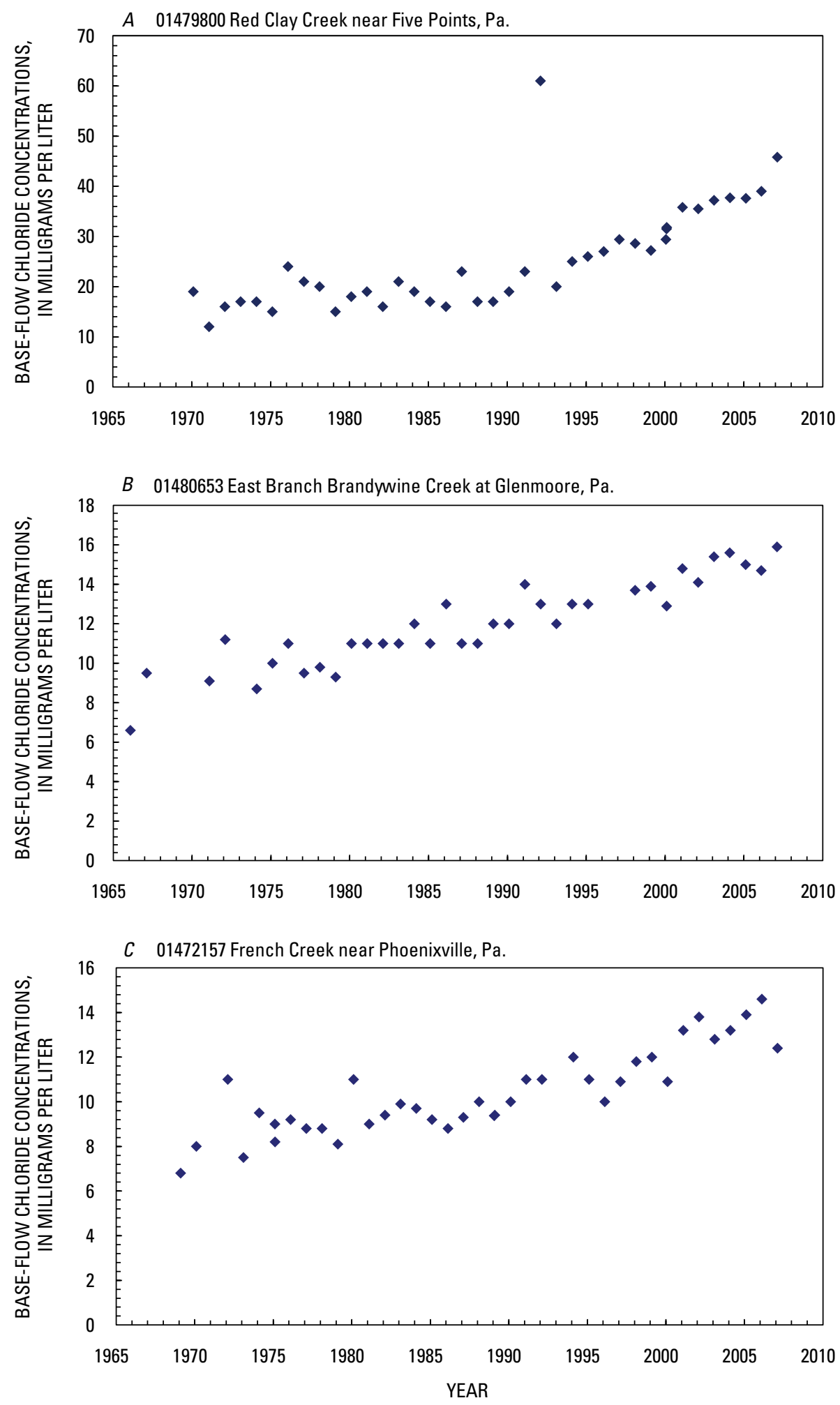

Figure 6. Chloride concentrations in base flow sampled annually in autumn at USGS streamgages: (A) 01479800 East Branch Red Clay Creek near Five Points, Pa., 1970-2007; (B) 01480653 East Branch Brandywine Creek near Glenmoore, Pa., 1969-2007; (C) 01472157 French Creek near Phoenixville, Pa., 1969-2007; (D) 01472080 Pigeon Creek near Slonaker, Pa., 1969-2007; and (E) 01472190 Pickering Creek near Phoenixville, Pa., 1967-2007. Locations of streamgage sites are shown on figure 4. 

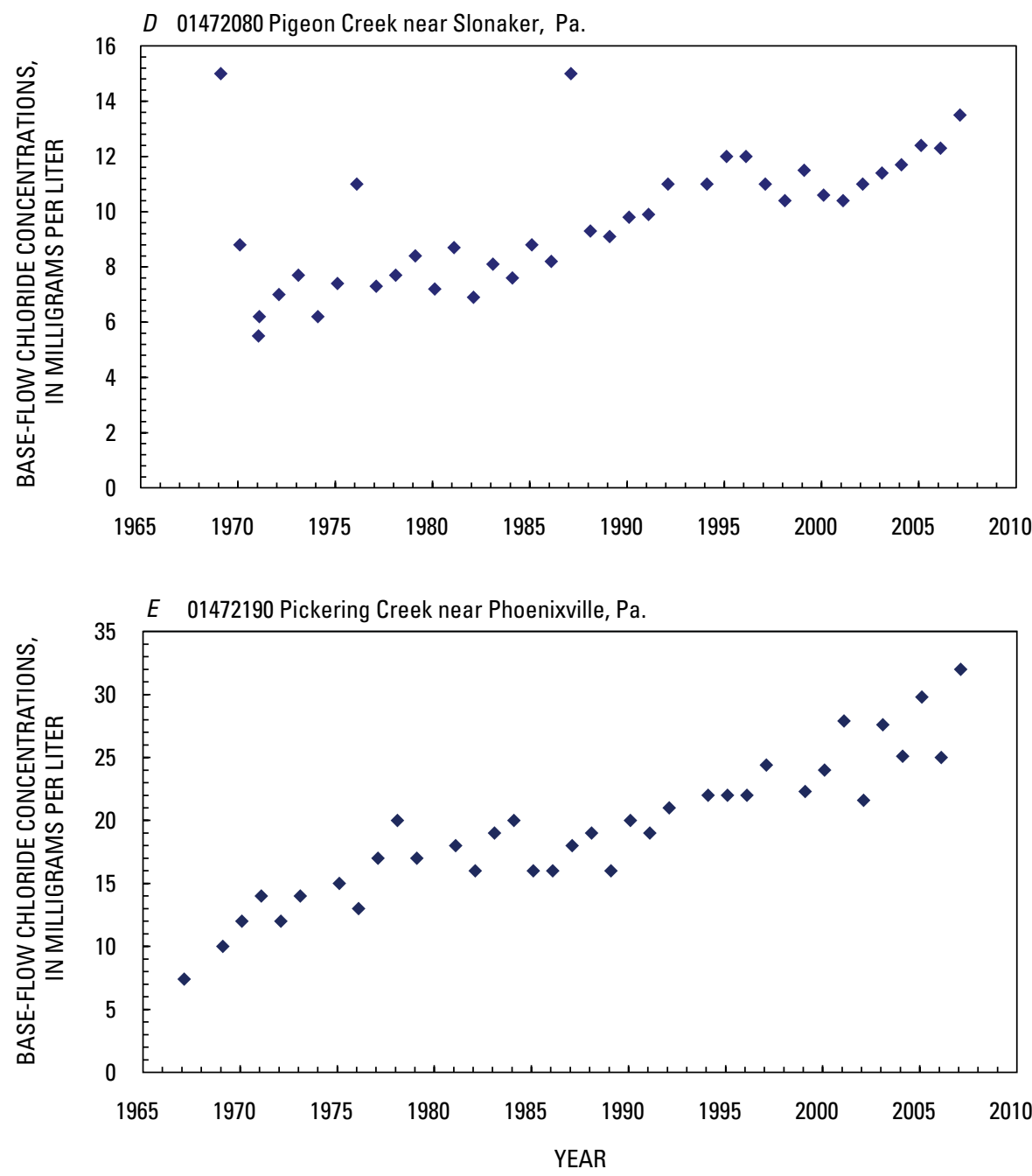

Figure 6. Chloride concentrations in base flow sampled annually in autumn at USGS streamgages: (A) 01479800 East Branch Red Clay Creek near Five Points, Pa., 1970-2007; (B) 01480653 East Branch Brandywine Creek near Glenmoore, Pa., 1969-2007; (C) 01472157 French Creek near Phoenixville, Pa., 1969-2007; (D) 01472080 Pigeon Creek near Slonaker, Pa., 1969-2007; and (E) 01472190 Pickering Creek near Phoenixville, Pa., 1967-2007.Continued. Locations of streamgage sites are shown on figure 4. 


\section{Results of Sampling for Naturally Occurring Constituents}

Data on general water chemistry and naturally occurring constituents in groundwater that may pose a risk to human health were collected through the groundwater-quality monitoring program. Groundwater quality is partly controlled by chemical reactions in the soil, saprolite (weathered rock), and underlying bedrock. Reactions include mineral dissolution, ion exchange, and adsorption. These natural controls differ by rock type.

\section{General Water Chemistry-pH, Alkalinity, Major Ions, Iron, and Manganese}

Field data on $\mathrm{pH}$, alkalinity, dissolved oxygen concentration, and specific conductance were collected on a routine basis for the groundwater-quality monitoring program. Concentrations of major ions, iron, and manganese also were commonly determined during sample analysis. These data can be used to understand and characterize the general water chemistry associated with each well sample and associated aquifer, including potential water-quality problems that exceed the SMCLs. For example, pH data can be used to evaluate the acidity of the groundwater, which affects corrosion of plumbing and mobilization of trace elements in the aquifer. Some trace elements, including lead and radium that pose risks to human health, are more soluble at low $\mathrm{pH}$ than at intermediate or high $\mathrm{pH}$.

In Chester County, SMCLs for $\mathrm{pH}$ (6.5-8.5), iron $(300 \mu \mathrm{g} / \mathrm{L})$, and manganese $(50 \mu \mathrm{g} / \mathrm{L})$ are the most frequently exceeded secondary standards. Iron concentrations are greater than the SMCL of $300 \mu \mathrm{g} / \mathrm{L}$ in more than 10 percent of well-water samples countywide, and manganese concentrations are greater than the SMCL of $50 \mu \mathrm{g} / \mathrm{L}$ in more than 20 percent (Sloto, 1994; Ludlow and Loper, 2004). The data on general water chemistry are summarized for major aquifer type in Chester County by Sloto (1994) and Ludlow and Loper (2004).

\section{Radionuclides}

Naturally occurring radionuclides (radioactive elements derived from the radioactive decay of uranium-238, thorium-238, and uranium-235), such as radium and radon, are present in some rocks, soils, and groundwater in Chester County. Radionuclides are unstable elements, with half-lives of varying lengths (from seconds to millions of years), and are part of radioactive decay series defined by the primary parent, such as uranium-238. Radionuclides with longer half lives typically are present in greater mass quantities than radionuclides with shorter half lives. Radionuclides may include radioactive isotopes of the same elements, such as radium-226 and radium-228, that are produced by the radioactive decay of different parent radionuclides. Radon-222, a gas, is produced from the decay of radium-226, itself a daughter product in the uranium-238 decay chain. Radioactive decay releases alpha or beta particles, the amount of which commonly is measured and reported as gross alpha-particle or gross beta-particle activity. Radionuclides and associated radioactivity may pose a risk to human health in drinking water. The USEPA has established MCLs for radium-226, radium-228, uranium, gross alpha particles, and gross beta particles and has proposed MCLs for radon-222 (table 3). The amount of radionuclides present in a sample commonly is reported in units of picocuries per liter, which is a measure of the rate of decay and is called an activity rather than a concentration.

Samples for analysis of naturally occurring radionuclides in Chester County were collected through the groundwaterquality monitoring program on an intermittent basis from 1984 through 2003. The results revealed that radionuclides are present in groundwater at levels that may pose health risks in some areas of the county. Radiochemical data collected through 2000 in southeastern Pennsylvania, including Chester County, are summarized by Sloto (2000) and through 2001 in Chester County by Ludlow and Loper (2004).

The CCHD has considered a recommendation that water samples from new wells drilled in the Chickies Quartzite and other quartzite units in the county (Setters Quartzite, Peters Creek Schist, Antietam and Harpers Formation, undivided) be screened for gross alpha-particle and (or) radium activities depending on the $\mathrm{pH}$ of the groundwater (Ralph DeFazio, Chester County Department of Health, oral commun., 2009). This recommendation to protect human health is based on results of the groundwater-quality monitoring program in Chester County and other studies of radionuclides in southeastern Pennsylvania (Senior and Vogel, 1995; Sloto, 2000).

\section{Radium and Radon}

In 1984, a sample from one well (CH-2429) in the Chickies Quartzite near a suspected dump was analyzed for selected radionuclides in addition to VOCs. Elevated activities of radium-226 and gross alpha particles were measured above the USEPA MCLs of 5 and $15 \mathrm{pCi} / \mathrm{L}$, respectively, for those constituents. In 1985, samples from five of six wells in the Chickies Quartzite were analyzed for radionuclides and found to have elevated radium-226, radium-228, and gross alpha-particle activities above USEPA MCLs (table 3), with up to $11 \mathrm{pCi} / \mathrm{L}$ for radium-226, $51 \mathrm{pCi} / \mathrm{L}$ for radium 228 , and $160 \mathrm{pCi} / \mathrm{L}$ for gross alpha. The Chickies Quartzite occurs in a band across central Chester County and in several other areas in northern Chester County (fig. 1).

In 1986, sampling was expanded to include 30 wells -8 in the Chickies Quartzite and 1 to 2 in each of 21 major geologic units in Chester County - to assess the potential for naturally occurring radionuclides countywide. In 1987, the countywide radionuclide reconnaissance was expanded and sampling included 18 wells in the Triassic rocks (shales and sandstones) of northern Chester County and 16 wells in quartzite and carbonate rocks. Water from 8 of the 64 wells 
sampled in 1986 and 1987 had radium-226, radium-228, or gross alpha-particle activities that exceeded USEPA MCLs. Of the eight wells, seven were completed in quartzite or quartzite schist (five in Chickies Quartzite, one in Peters Creek Schist, one in Antietam and Harpers Formation, undivided) and one in carbonate rock (Ledger Dolomite) that also had an elevated uranium concentration. On the basis of these reconnaissance data, the geologic units most likely to have elevated radium and gross alpha-particle activities in groundwater in Chester County are the Chickies Quartzite and other quartzites, although other geologic rock units in the county also have potential for elevated radioactivity in groundwater.

Subsequently, a study of radium and radon in groundwater in the Chickies Quartzite in southeastern Pennsylvania, done by USGS in cooperation with three Pennsylvania state agencies (Senior and Vogel, 1995), indicated combined radium-226 plus radium-228 activities exceeded the MCL of $5 \mathrm{pCi} / \mathrm{L}$ in more than 40 percent of 160 well-water samples collected in Chester County and 5 other nearby counties in southeastern Pennsylvania. Of the 45 well samples collected in Chester County for the study, 62 percent exceeded the MCL for combined radium. Elevated radium activities correlated with acidic groundwater, and all samples with $\mathrm{pH}$ of 4.7 or lower had elevated combined radium activities.

Starting in 1986, groundwater samples collected for the Chester County groundwater-quality monitoring program were analyzed for radon-222, a radioactive gas that is the daughter product of radium-226 radioactive decay. From 1987 through 2000, all samples collected through the Chester County groundwater-quality monitoring program were analyzed for radon-222. These data and data collected through other projects from 1986 through 1997 were summarized and discussed by Senior (1998) and data collected from 1986 to 2001 was summarized by Ludlow and Loper (2004). Results indicate that radon-222 activities exceeded the proposed MCL of $300 \mathrm{pCi} / \mathrm{L}$ for 89 percent of the wells and exceeded the alternative proposed MCL of $4,000 \mathrm{pCi} / \mathrm{L}$ for 18 percent of the wells sampled in Chester County (Ludlow and Loper, 2004). The highest measured radon-222 activity in groundwater in the county was $53,000 \mathrm{pCi} / \mathrm{L}$. Radon-222 activities in groundwater differ by geologic unit. The Peters Creek Schist has the highest median radon-222 activities in groundwater in the county (Senior, 1998).

In addition to spatial data collected on radon-222 and other radionuclides throughout Chester County, some wells were sampled on fixed time intervals as part of the groundwater-quality monitoring program to investigate the range of and possible seasonal fluctuations in radon activities in groundwater. Results, discussed by Senior (1998), showed that five wells sampled bimonthly in 1996-97 had no clear seasonal pattern in radon-222 activities in groundwater, although 1996 was an unusually wet year and may not be representative of typical seasonal cycles. Sampling of another well (CH-3335) on a monthly interval for about 3 years starting in 1989, however, showed strong seasonal fluctuations in radon and radium activities; radium activities were highest in the fall and lowest in the spring. The implications of seasonal fluctuations in groundwater quality may be that drinking-water standards could be exceeded seasonally but might not be detected if the well were not sampled during the time of year when maximum concentrations occur.

In 1999, 14 wells previously sampled in 8 different geologic units for analyses of radium-226 and radium-228 were resampled through the monitoring program for analyses of radium-226, radium-228, and radium-224 (a shortlived radionuclide derived from the decay of radium-228). The geologic units included quartzites (two wells in Setters Quartzite and four wells in Chickies Quartzite), quartzschist (two wells in Antietam and Harpers Formation, undivided and one well in Peters Creek Schist), gneiss (one well in felsic gneiss), carbonates (one well each in Conestoga Limestone and Ledger Dolomite), and shale (two wells in Brunswick Group). Radium-224 has a half-life of 3.6 days and decays by emitting alpha particles. Its presence may be associated with elevated gross alpha-particle activity especially in the first few days after sample collection. The short-lived nature of the alpha-emitting radium-224 contributes to gross alpha-particle activity and has implications regarding the MCL for gross alpha-particle activity and the amount of holding time before sample analysis (Focazio and others, 2001). Radium-224 activities up to $265 \mathrm{pCi} / \mathrm{L}$ and gross alpha-particle activities up to $1,290 \mathrm{pCi} / \mathrm{L}$ were measured in a sample from one well (CH-3331) completed in the Chickies Quartzite. Samples from 7 of the 14 wells had gross alpha-particle activities greater than the USEPA MCL of $15 \mathrm{pCi} / \mathrm{L}$ (fig. 7). Although the USEPA has not established a MCL for radium-224, standards have been established in other countries to protect human health, such as the Canadian drinking-water guideline of $54 \mathrm{pCi} / \mathrm{L}$ ( 2 bequerel) for radium-224 (Health Canada, 2008). In addition to the sample from well CH-3331, a sample from a second well in the Chickies Quartzite (CH-1616) had radium-224 activity ( $61 \mathrm{pCi} / \mathrm{L})$ exceeding the Canadian standard. Radium-224 activities in the water samples from 14 wells correlated with gross alpha-particle and radium-228 activities (fig. 7).

Radium-224 is likely to occur where radium-228 is present in groundwater, which in Chester County includes quartzite and quartzite schists (Senior and Sloto, 2000) (fig. 1). The radium-224 activity of $265 \mathrm{pCi} / \mathrm{L}$ measured in the well-water sample collected in 1999 in Chester County is one of the highest reported in the United States, exceeding the maximum activity of $73.6 \mathrm{pCi} / \mathrm{L}$ radium-224 reported in a nationwide targeted survey of radionuclides in public drinking-water supplies in areas with known or suspected elevated radium in groundwater (Focazio and others, 2001).

\section{Gross Alpha-Particle and Beta-Particle Activity and Other Radionuclides}

In 2003, samples from 18 wells collected to investigate lead concentrations in the Chickies Quartzite (discussed in a later section) were also analyzed for gross alpha-particle 

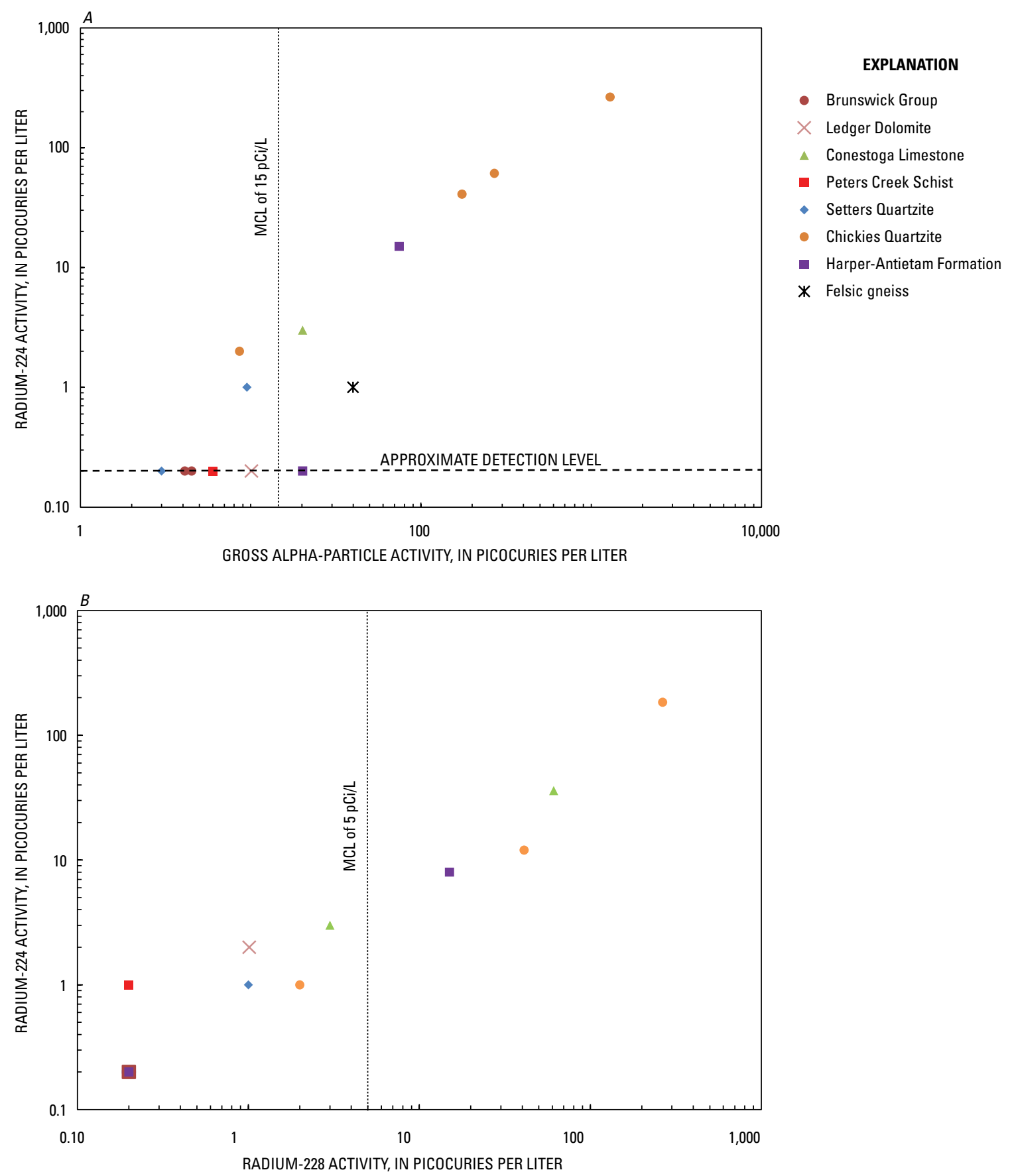

Figure 7. Radium-224 activities in relation to $(A)$ gross alpha-particle activities and $(B)$ radium-228 activities in samples from 14 wells in 9 different geologic units, Chester County, Pa., 1999. 
activities measured at two different times after sample collection (72 hours and 30 days) and the radioactive isotope lead-210 (also discussed later in the section on lead). Gross alpha-particle activities at 30 days exceeded the USEPA MCL of $15 \mathrm{pCi} / \mathrm{L}$ in 8 of the 18 well-water samples collected in 2003; elevated activities ranged from 15.9 to $75.7 \mathrm{pCi} / \mathrm{L}$. Gross alpha-particle activities measured at 72 hours generally were greater than activities at 30 days (fig. 8), indicating the presence of short-lived alpha-particle-emitting radionuclides such as radium-222. In one sample, gross alpha-particle activities measured at 72 hours were above the MCL of $15 \mathrm{pCi} / \mathrm{L}$, but the 30-day gross alpha-particle activity was less than $15 \mathrm{pCi} / \mathrm{L}$. The difference between the gross alpha-particle activity at 72 hours and 30 days measured in these samples ranged up to a factor of 7 and showed that short-lived radionuclides are present in groundwater. Therefore, the use of gross alpha-particle activity measurements at 30 days may be insufficient to monitor potential exceedances of MCLs in some settings, as has been noted by Focazio and others (2001) for areas in New Jersey with radium-224 in groundwater. Gross alpha-particle activities appeared inversely related to $\mathrm{pH}$, with higher gross alpha-particle activities associated with lower (acidic) $\mathrm{pH}$ values. All five samples with $\mathrm{pH}$ below 5.0 had gross alpha-particle activities above the MCL (fig. 9). Elevated gross alpha-particle activities in groundwater probably are related to the presence of radium-226, radium-224, and other radionuclides that decay by alpha-particle emission.

In 2006, samples from 10 wells analyzed for dissolved and total lead were also analyzed for gross alpha-particle and beta-particle activities measured at 72 hours and at 30 days. The wells were completed in different geologic units, including sandstone, carbonate, gneiss, schist, and quartzite rocks. Gross alpha-particle and beta-particle activities were substantially greater (by more than $9 \mathrm{pCi} / \mathrm{L}$ ) at 72 hours compared to activities at 30 days in samples from only two wells (CH-3334 and $\mathrm{CH}-3365$ ), and both those wells were completed in the Chickies Quartzite. Gross alpha-particle activities at 72 hours were slightly higher $(3.3 \mathrm{pCi} / \mathrm{L}$ or 47 percent $)$ than at 30 days in a sample from a well in Setters Quartzite (CH-2766). The decline in measured activities from 72 hours to 30 days indicates the presence of short-lived radionuclides such as radium-224 and its progeny that have been shown to occur in groundwater in the Chickies Quartzite through samples collected in 1999 as part of the monitoring program.

\section{Arsenic}

Arsenic is a naturally occurring element that may be present in groundwater in concentrations that pose a risk to human health. The USEPA lowered the MCL for arsenic in drinking water from 50 to $10 \mu \mathrm{g} / \mathrm{L}$ in 2006 and lists a HA level of $2 \mu \mathrm{g} / \mathrm{L}$ (U.S. Environmental Protection Agency, 2009a). Through the groundwater-quality monitoring program, data on arsenic concentrations in Chester County were collected periodically by sampling near possible sources, including those that are associated with human activities such as

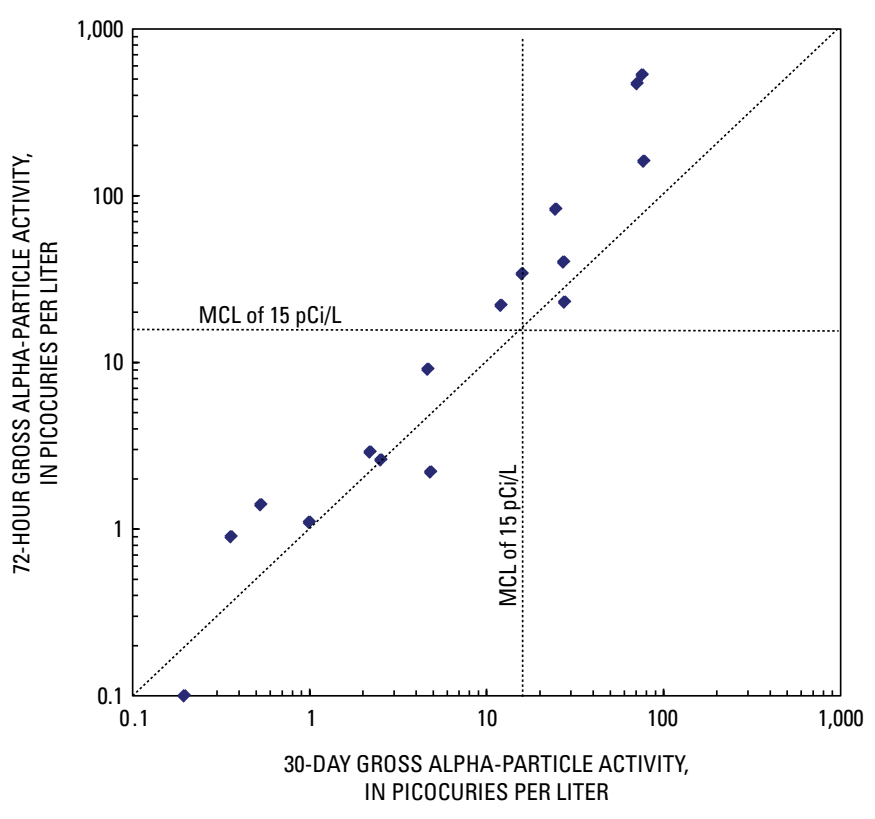

Figure 8. Relation between 72-hour gross alpha-particle activities and 30-day gross alpha-particle activities in groundwater samples from 18 wells in the Chickies Quartzite or Antietam and Harpers Formation, undivided, Chester County, Pa., 2003.

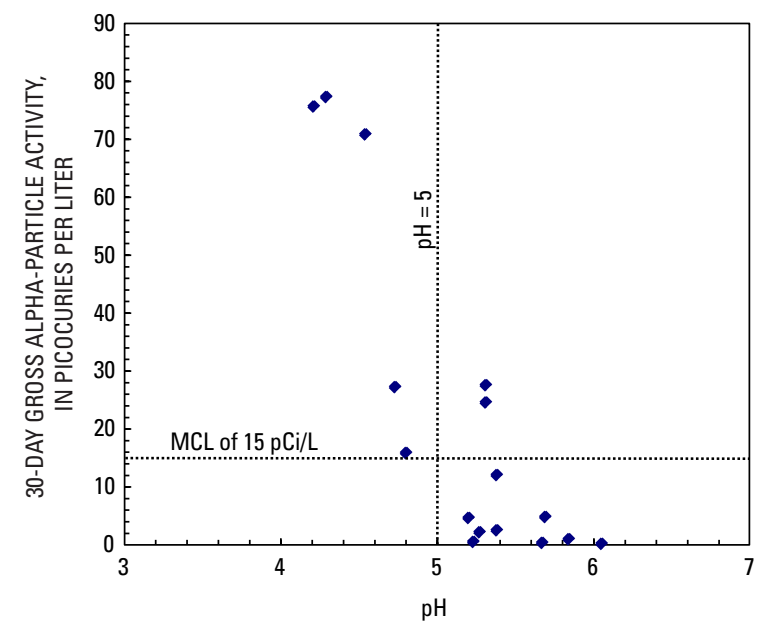

Figure 9. Relation between 30-day gross alpha-particle activities and $\mathrm{pH}$ in groundwater samples from 18 wells in the Chickies Quartzite or Antietam and Harpers Formation, undivided, Chester County, Pa., 2003. 
orchards (where arsenic may have been used as a pesticide) and cemeteries (arsenic used in embalming agents) and those that are naturally occurring such as near mineralized areas. Arsenic concentrations in groundwater greater than the MCL of $10 \mu \mathrm{g} / \mathrm{L}$ were rare, occurring in only 2 or less than 1 percent of about 450 samples from 372 wells. Arsenic concentrations greater than the HA level of $2 \mu \mathrm{g} / \mathrm{L}$ were more common and were measured in about 13 percent of the samples.

On the basis of data collected through the groundwaterquality monitoring program and elsewhere in southeastern Pennsylvania (Senior and Sloto, 2006), groundwater in the Triassic rocks in northern Chester County (fig. 1) is the most likely geologic setting in the county to have elevated arsenic concentrations from natural sources. Concentrations of arsenic greater than or equal to the HA level of $2 \mu \mathrm{g} / \mathrm{L}$ were present in about 40 percent of samples from 41 wells in the Triassic geologic units and in only about 7 percent or less of water samples from wells in other geologic units in Chester County. About 20 percent of samples from the 41 wells in the Triassic rocks in northern Chester County had $5 \mu \mathrm{g} / \mathrm{L}$ or more of dissolved arsenic, although concentrations exceeded the MCL of $10 \mu \mathrm{g} / \mathrm{L}$ in only one sample (from well CH-5556) that had $69 \mu \mathrm{g} / \mathrm{L}$. Less than 2 percent of samples from wells in other geologic units had arsenic concentrations greater than $5 \mu \mathrm{g} / \mathrm{L}$, and in these samples, the highest concentration was $10 \mu \mathrm{g} / \mathrm{L}$. Evaluation of available arsenic data in groundwater in Triassic rocks in Chester County and three nearby counties in southeastern Pennsylvania indicated that about 10 percent of well-water samples have arsenic concentrations that exceed the MCL of $10 \mu \mathrm{g} / \mathrm{L}$ (Senior and Sloto, 2006). Arsenic in groundwater in the Triassic rocks in Chester County and nearby counties likely is naturally occurring. Studies of similar rocks in New Jersey (Serfes, 2006; Serfes and Spayd, 2006) showed that arsenic in groundwater was derived from natural aquifer materials.

\section{Lead}

Data on concentrations of dissolved lead in groundwater were collected through the monitoring program at various times. Results, as reported by Sloto (1994) for 1980-89 and by Ludlow and Loper (2004) for 1990-2001, suggest that fewer than 5 percent of 514 well-water samples contained dissolved lead in concentrations above the USEPA action level of $15 \mu \mathrm{g} / \mathrm{L}$ for drinking water. Lead is a naturally occurring element but also is present in some plumbing. Lead may be mobilized from natural sources (minerals) or other sources under some geochemical conditions (such as low $\mathrm{pH}$ or acidic water). Reported occurrences of elevated lead in groundwater from some wells in the Chickies Quartzite prompted additional study. Lead in groundwater was the focus of the groundwaterquality monitoring program in 2003, 2004, and 2006.

In 2003, 18 wells were sampled for concentrations of dissolved and total lead in areas underlain by the Chickies Quartzite and (or) the Antietam and Harpers Formations, undivided, near the Blosenki Superfund site and elsewhere in
Chester County as a follow-up to USEPA and county findings of elevated lead concentrations in water. In addition to lead, samples were analyzed for major ions, nutrients, selected trace elements (arsenic, boron, iron, and manganese), the isotope lead-210, radon-222, and gross alpha-particle activity. Gross alpha-particle activities were analyzed in part to verify earlier findings in groundwater in the Chickies Quartzite. Lead-210 was analyzed to determine if radioactive decay might be a source of lead in groundwater. Lead-210 is a product of the radioactive decay of radon-222, which itself is a decay product of radium-226. Elevated activities of radium-226, radium-228, and radon-222 in addition to gross alpha particle, have been documented in groundwater in the Chickies Quartzite through the monitoring program and other studies (Senior and Vogel, 1995).

Results of the 2003 sampling showed that water from only 1 ( 5.5 percent) of the 18 wells sampled had concentrations of dissolved and (or) total lead greater than the USEPA action level of $15 \mu \mathrm{g} / \mathrm{L}$. The highest concentration was $19.9 \mu \mathrm{g} / \mathrm{L}$ of total lead. Concentrations of dissolved lead ranged from 0.2 to $8.8 \mu \mathrm{g} / \mathrm{L}$, and concentrations of total lead ranged from 0.3 to $19.9 \mu \mathrm{g} / \mathrm{L}$. Most (16 of 18 or about 90 percent) of the concentrations of total lead were less than $5 \mu \mathrm{g} / \mathrm{L}$. The difference between concentrations of dissolved and total lead was less than $1 \mu \mathrm{g} / \mathrm{L}$ in 14 of the 18 well-water samples, and in the other 4 well-water samples, the concentrations of total lead were greater than concentrations of dissolved lead by 1.3 to $18.6 \mu \mathrm{g} / \mathrm{L}$. Concentrations of dissolved and total lead appear inversely related to $\mathrm{pH}$, such that the lower the $\mathrm{pH}$, generally the higher the concentrations of lead (fig. 10). The field $\mathrm{pH}$ for the 17 samples ranged from 4.2 to 6.1 , and lead concentrations were above $1 \mu \mathrm{g} / \mathrm{L}$ in all samples with $\mathrm{pH}$ below 5.2. Gross alpha-particle activities in these samples (discussed earlier) generally also were inversely related to $\mathrm{pH}$, such that both higher gross alpha-particle activities and dissolved lead concentrations were associated with lower $\mathrm{pH}$ values.

Activities of the isotope lead-210 did not appear to correlate with concentrations of dissolved or total lead but did appear to correlate with activities of radon-222 (fig. 11), a parent in the radioactive decay chain. These results suggest that the radioactive decay of radon-222 is a primary source of lead210 in the samples although there also may be other sources. Lead- 210 activities ranged from 0.1 to $3 \mathrm{pCi} / \mathrm{L}$, and associated radon-222 activities ranged from 200 to $15,600 \mathrm{pCi} / \mathrm{L}$ (fig. 11). Although the USEPA has not established a MCL for lead-210, the agency included lead-210 on a list for unregulated contaminant monitoring in 1999 (U.S. Environmental Protection Agency, 1999) and other countries have established standards, such as the Canadian guideline of $2.7 \mathrm{pCi} / \mathrm{L}$ ( 0.1 bequerel per liter) lead-210 in drinking water (Health Canada, 2008). The highest measured lead- 210 activity of $3 \mathrm{pCi} / \mathrm{L}$ in the 2003 well-water samples was above the Canadian guideline of $2.7 \mathrm{pCi} / \mathrm{L}$ for lead-210 in drinking water. Decay of lead-210 produces polonium-210, a potentially hazardous radionuclide that was not analyzed in these samples. 


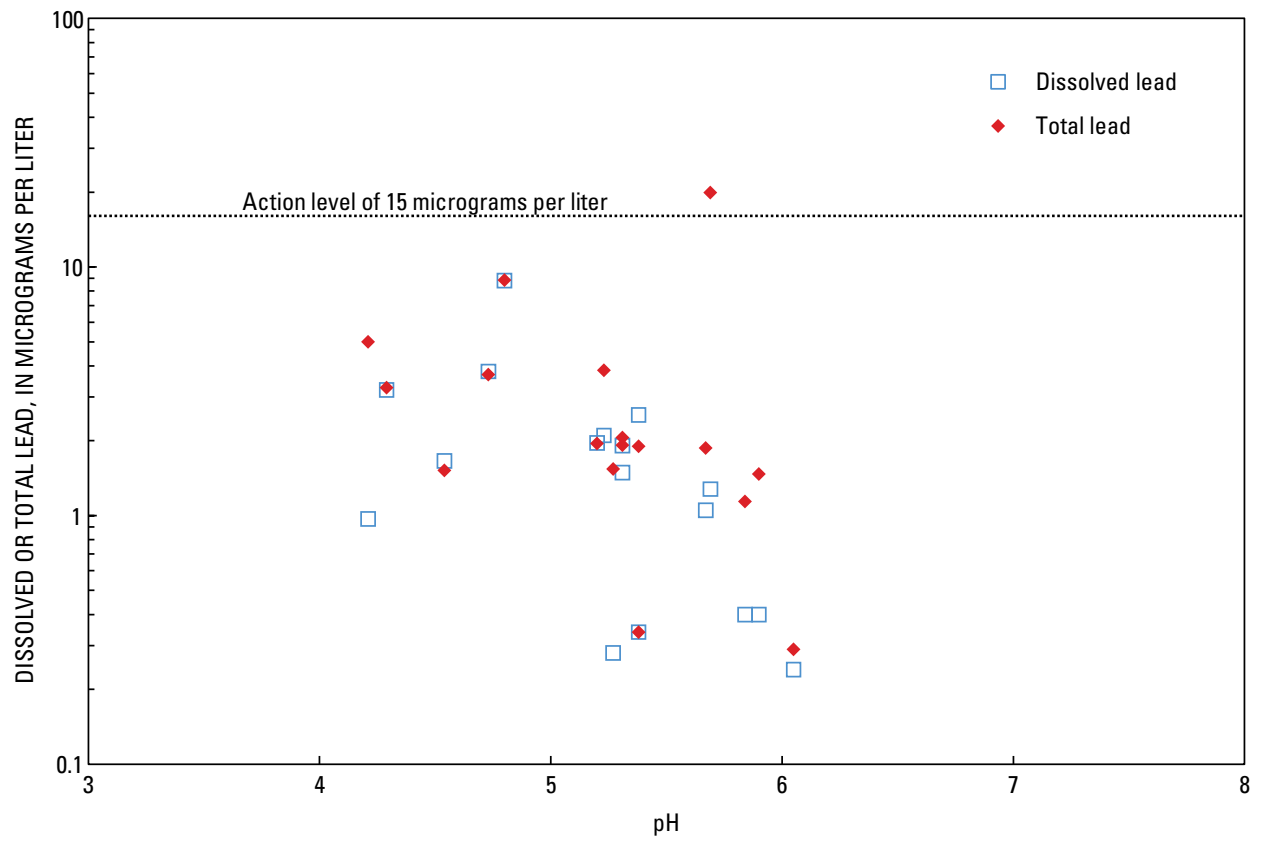

Figure 10. Relation between concentrations of dissolved and total lead and $\mathrm{pH}$ in groundwater samples from 17 wells in the Chickies Quartzite or Antietam and Harpers Formation, undivided, Chester County, Pa., 2003.

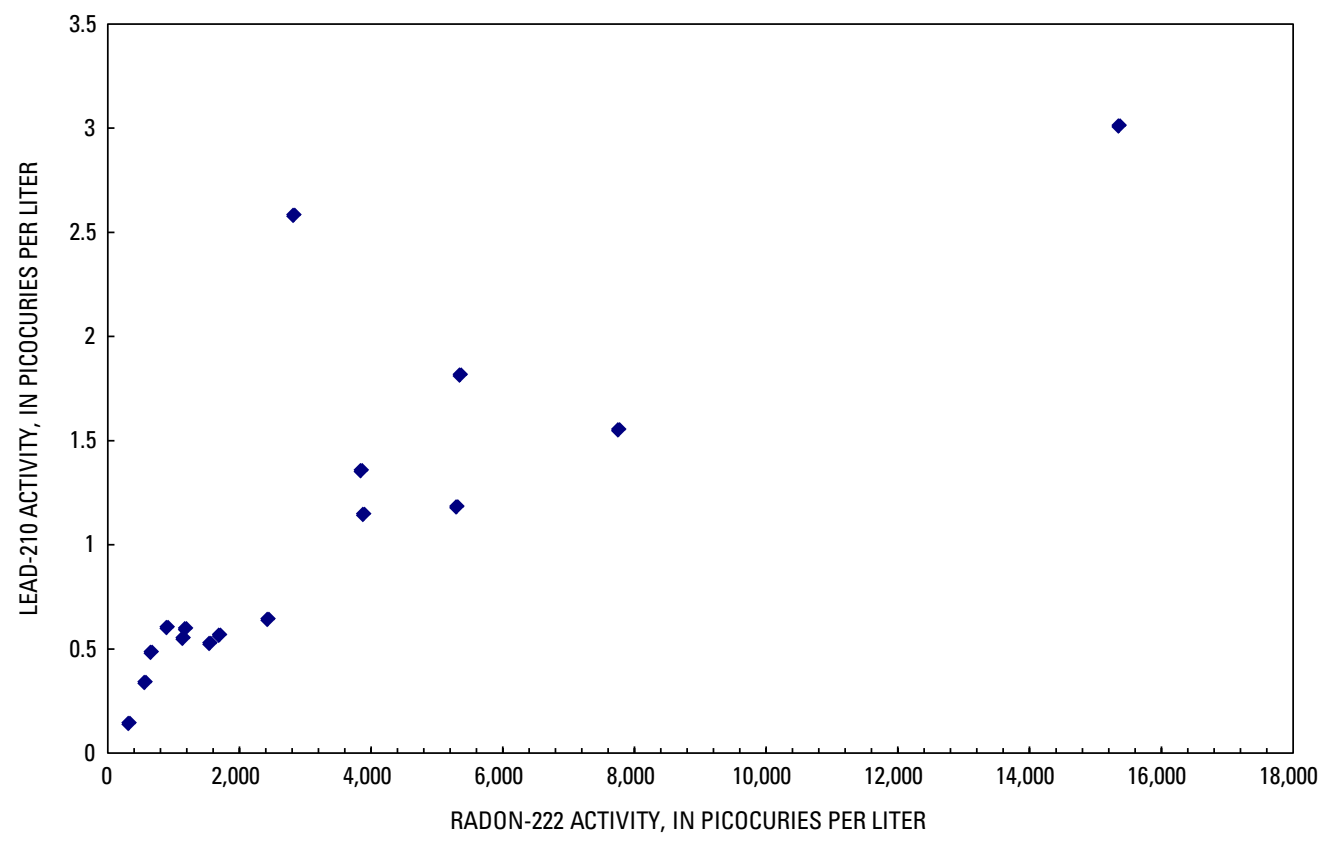

Figure 11. Relation between lead-210 activities and radon-222 activities in groundwater samples from 17 wells in the Chickies Quartzite or Antietam and Harpers Formation, undivided, Chester County, Pa., 2003. 
In 2004, USGS data on lead in groundwater in the county were reviewed to determine the extent of possible lead concentrations higher than the USEPA action level of $15 \mu \mathrm{g} / \mathrm{L}$. Data were compiled and relations between dissolved lead and selected chemical properties and constituents and geology were cursorily evaluated. The data on lead concentrations in well-water samples were collected over a period of more than 30 years, during which time changes in laboratory and sampling methodology occurred, in addition to possible changes in well-owners' plumbing and natural conditions. The 2004 data evaluation did not include screening of the data for different laboratory detection levels or other methodologies, which may affect some of the preliminary findings. The unpublished, internal 2004 review of data on lead in groundwater resulted in the following observations.

Data on concentrations of dissolved lead were available for 545 wells (690 samples), and concentrations were detected above the reporting level for 290 wells (331 samples collected between 1972-2003); 35 samples from 31 wells were reported to have a concentration equal to 0 . Data on concentrations of dissolved and total lead were available for 20 wells - 3 wells in 2001 in the French Creek mine area and 17 wells in 2003 in the quartzites.

To evaluate the possible role of water quality on solubility of lead from either man-made sources, such as plumbing, or natural deposits, relations between lead and other metals possibly associated with plumbing (such as copper and zinc) and between lead and geochemical factors such as $\mathrm{pH}$ (acidity) were determined for the complete data set that included groundwater samples from numerous different geologic units. Most groundwater samples collected for the groundwatermonitoring program were from domestic wells through existing plumbing, a possible source of metals such as copper and lead. To minimize contamination from plumbing, groundwater samples were collected after pumping the well (for variable amounts of time that typically ranged from 0.5 to 1.5 hours) to purge water that had been in contact with plumbing. For the 290 well-water samples with concentrations of dissolved lead above the reporting level, dissolved lead did not appear to correlate with the dissolved metals copper, iron, manganese, or zinc, suggesting that sources other than metal plumbing may contribute lead or that plumbing composition varies too widely to correlate with lead. Dissolved lead did not appear to correlate with $\mathrm{pH}$ when data for all geologic units were combined, suggesting that $\mathrm{pH}$ is not the sole factor controlling solubility of lead. Of the metals copper, lead, and zinc, only copper concentrations appeared to correlate with $\mathrm{pH}$, with dissolved copper concentrations increasing as $\mathrm{pH}$ decreases. These results suggest that copper may be more easily dissolved than the other metals from natural sources and (or) plumbing despite purging in acidic water. Further, concentrations of dissolved lead did not appear to be related to the age of the well and the inferred age of plumbing nor to the reduction in lead content of solder in the 1980s.

Lead data were grouped by geologic unit to determine the relation between geology and concentration of dissolved lead in groundwater. The highest concentrations of lead generally were in samples from quartzites, carbonates, and gneisses (in descending order). Concentrations at or above the USEPA action level of $15 \mu \mathrm{g} / \mathrm{L}$ were reported for 17 (5 percent) of the 331 samples, including water samples from wells drilled in the Octoraro Phyllite (15 to $70 \mu \mathrm{g} / \mathrm{L}$ ), Chickies Quartzite $(15$ to $50 \mu \mathrm{g} / \mathrm{L})$, Setters Quartzite $(30 \mu \mathrm{g} / \mathrm{L})$, Conestoga Limestone $(24 \mu \mathrm{g} / \mathrm{L})$, felsic gneiss-granulite facies $(24 \mu \mathrm{g} / \mathrm{L})$, Stockton Formation $(20 \mu \mathrm{g} / \mathrm{L})$, Peters Creek Schist $(20 \mu \mathrm{g} / \mathrm{L})$, Wissahickon Formation $(20 \mu \mathrm{g} / \mathrm{L})$, Elbrook Limestone $(20 \mu \mathrm{g} / \mathrm{L})$, Ledger Dolomite $(20 \mu \mathrm{g} / \mathrm{L})$, and felsic gneiss, hornblende-bearing $(20 \mu \mathrm{g} / \mathrm{L})$. Another 22 samples $(6.6$ percent) that contained 10 to $14 \mu \mathrm{g} / \mathrm{L}$ dissolved lead are mostly from these units.

The relation between concentrations of dissolved and total lead was investigated on the basis of a limited number (20) of groundwater samples that were collected mostly from wells (17) in quartzite in 2003 and a few wells (3) in other formations in 2001. In these samples, concentrations of dissolved lead generally appear to be greater in samples with a $\mathrm{pH}$ less than 5 compared to samples with a $\mathrm{pH}$ greater than 6 , suggesting that $\mathrm{pH}$ is a control on lead in groundwater in quartzite aquifers. The highest concentration of total lead $(19.9 \mu \mathrm{g} / \mathrm{L})$ was in a sample with a $\mathrm{pH}$ of 5.7 that had $1.3 \mu \mathrm{g} / \mathrm{L}$ of dissolved lead. The ratio of dissolved to total lead concentrations appears to vary with $\mathrm{pH}$, where for samples with $\mathrm{pH}$ less than 5 , dissolved lead typically equals total lead; with $\mathrm{pH}$ of 5 to 5.5 , ratio of dissolved to total varies widely; with $\mathrm{pH}$ of 5.5 to 6 , dissolved lead represents 60 percent or less of total lead (fig. 12). In the one sample with $\mathrm{pH}$ greater than 6 , dissolved lead represents about 80 percent of total lead.

To clarify preliminary findings from the 2003 samples and the unpublished 2004 review, 30 wells in 15 different geologic units were sampled in 2006 for dissolved and total lead to provide data for geologic units that were identified in 2004 as having potential lead problems and on the relation between dissolved and total lead. Of the 30 wells sampled in 2006, 20 wells were previously sampled for dissolved lead. Almost all the historical analyses for lead in groundwater in Chester County were filtered samples, which yield data on concentrations of dissolved lead. In addition to dissolved and total lead, the 2006 samples were analyzed for major ions, nutrients, and selected trace elements (arsenic, boron, iron, manganese, and uranium). Samples from 10 wells also were analyzed for gross alpha-particle and gross beta-particle activities to provide data on the relation between lead and radioactivity.

Results of the 2006 sampling suggested that elevated dissolved lead concentrations are not frequent countywide and included the following observations. Water from only 1 (3 percent) of 30 wells had concentrations of dissolved and (or) total lead greater than the USEPA action level of $15 \mu \mathrm{g} / \mathrm{L}$. The maximum concentration was $18.6 \mu \mathrm{g} / \mathrm{L}$ for dissolved lead and $13.3 \mu \mathrm{g} / \mathrm{L}$ for total lead. The difference between concentrations of dissolved and total lead was less than $1 \mu \mathrm{g} / \mathrm{L}$ in 22 (73 percent) of the 30 well-water samples. In seven of the other eight samples for which the difference between 


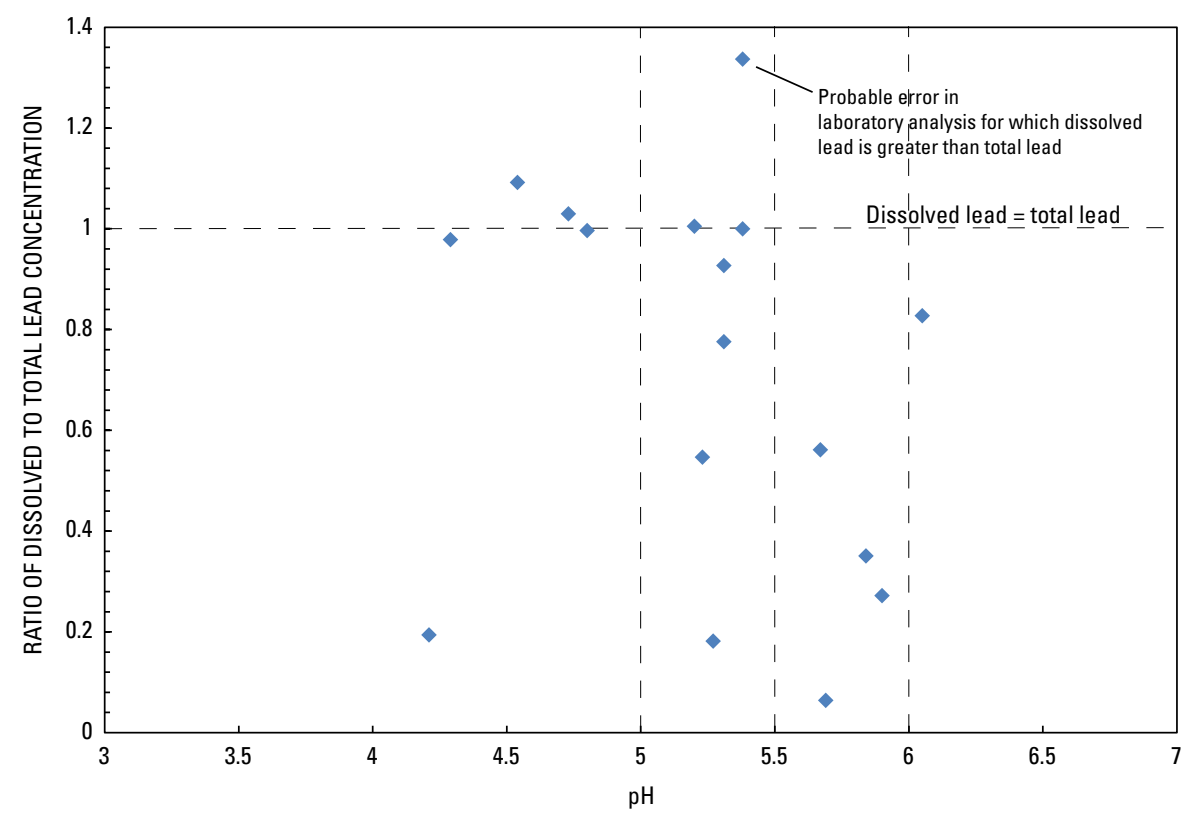

Figure 12. Relation between $\mathrm{pH}$ and the ratio of dissolved to total lead concentrations in groundwater samples from 17 wells in the Chickies Quartzite or Antietam and Harpers Formation, undivided, Chester County, Pa., 2003.

concentrations of dissolved and total lead was greater than $1 \mu \mathrm{g} / \mathrm{L}$, the concentrations of total lead were greater than the concentrations of dissolved lead by 1 to $13 \mu \mathrm{g} / \mathrm{L}$. These results indicate that dissolved lead data may underpredict concentrations of total lead in some samples by as much as $13 \mu \mathrm{g} / \mathrm{L}$. In one well-water sample, the reported concentration of dissolved lead of $18.6 \mu \mathrm{g} / \mathrm{L}$ was $14.7 \mu \mathrm{g} / \mathrm{L}$ greater than the concentration of total lead, a difference that suggests error in one of the analyses or contamination. Concentrations of total lead less than the MCL but greater than $7 \mu \mathrm{g} / \mathrm{L}$ (a concentration equal to half the USEPA action level that might be used to screen for potential problems) were measured in water from one well drilled in the Setters Quartzite and one well drilled in the Wissahickon Formation; a concentration of dissolved lead greater than $7 \mu \mathrm{g} / \mathrm{L}$ was measured in water from one well drilled in the Chickies Quartzite.

In samples collected in 2006 from the 30 wells, concentrations of dissolved copper and dissolved and total lead were inversely related to $\mathrm{pH}$; generally, the lower the $\mathrm{pH}$, the higher the concentrations of lead and copper. The sample with the highest concentration of dissolved lead $(18.6 \mu \mathrm{g} / \mathrm{L})$ had the lowest $\mathrm{pH}$ (4.6). Concentrations of dissolved copper and lead appeared to correlate positively, suggesting a possible plumbing source for these metals. These findings differ slightly from the unpublished 2004 review of data; the 2004 review did not show a strong relation between $\mathrm{pH}$ and concentrations of lead and copper. The 2006 findings differ from the unpublished 2004 review possibly because of differences in accuracy of historical trace metal analyses and reported lead concentrations. Water from the 20 wells that were previously sampled had concentrations of dissolved lead in 2006 that generally were either similar or lower than in previous samples. Concentrations of dissolved lead in 2006 were lower than in previous years in water from 10 wells, were similar to previous years in water from 9 wells, and were higher than in previous years in water from 1 well. The concentrations of dissolved lead in samples from the 20 wells collected prior to 2006 ranged from the detection level (less than 1 to less than $10 \mu \mathrm{g} / \mathrm{L}$ ) to $50 \mu \mathrm{g} / \mathrm{L}$. Only one of the five samples from wells that had concentrations of dissolved lead above the USEPA action level of $15 \mu \mathrm{g} / \mathrm{L}$ prior to $2006 \mathrm{had}$ concentrations of dissolved or total lead above $15 \mu \mathrm{g} / \mathrm{L}$ in 2006 ; this sample had a concentration of $50 \mu \mathrm{g} / \mathrm{L}$ when sampled in 1989 and of $18.6 \mu \mathrm{g} / \mathrm{L}$ when sampled in 2006 and was from a well drilled in the Chickies Quartzite. Differences in lead concentrations through time may be affected by changes in sampling and laboratory methods or household plumbing, as well as by natural variability.

Samples from 3 of 10 wells analyzed in 2006 for gross alpha-particle and gross beta-particle activities had gross alpha-particle activity greater than the USEPA MCL of $15 \mathrm{pCi} / \mathrm{L} ; 2$ of the wells were drilled in the Chickies Quartzite and 1 well was drilled in the Conestoga Formation (carbonate rock). Lead concentrations did not appear to correlate strongly with gross alpha-particle and gross beta-particle activities. However, water from one of the Chickies Quartzite wells had the highest gross alpha-particle activity $(54 \mathrm{pCi} / \mathrm{L}$ at 30 days) and the highest concentration of dissolved lead $(18.6 \mu \mathrm{g} / \mathrm{L})$ of the 30 wells sampled, indicating that lead may be produced from radioactive decay of naturally occurring aquifer materials and remain mobile (dissolved) in acidic groundwater in the quartzite. 
Overall, the data collected in 2003 and 2006 and the unpublished review of lead data in 2004 suggest that relatively few (less than 10 percent) wells in the county are likely to produce water with lead concentrations greater than the action level of $15 \mu \mathrm{g} / \mathrm{L}$. Elevated lead concentrations may occur sporadically and may be related to plumbing (including the pump in the well) or naturally occurring lead in the aquifer. Some wells in the Chickies Quartzite have elevated concentrations of dissolved lead that appear associated with low $\mathrm{pH}$. Some geologic units, including the Chickies Quartzite and other quartzites in the county, have naturally occurring low $\mathrm{pH}$ (acidic) groundwater. Elevated gross alpha-particle activities in the water from wells in the Chickies Quartzite also are associated with low pH. Limited data collected in 2003 indicated no strong relation between lead-210 derived from radioactive decay of radon-222 and measured concentrations of lead in well-water samples, although some lead in groundwater may be derived from radionuclides in the rock. Lead from natural and anthropogenic sources may be mobilized in low $\mathrm{pH}$ water so that both radium and lead may be present in acidic groundwater in the Chickies Quartzite and geologic units with similar composition. However, elevated lead concentrations also may occur in water samples from wells in carbonate rocks with $\mathrm{pH}$ generally close to 7 (neutral $\mathrm{pH}$ ).

\section{Summary and Conclusions}

The groundwater-quality monitoring program conducted by the U.S. Geological Survey (USGS) in cooperation with the Chester County Water Resources Authority and the Chester County Health Department in Chester County, Pa., began in 1980, partly in response to concerns at the time about possible contamination in groundwater that might pose a risk to human health. The groundwater-quality monitoring program consists of the annual collection of groundwater and occasional stream base-flow samples at various sites selected each year. Sample selection is done by USGS in consultation with the Chester County Water Resources Authority and the Chester County Health Department to meet one or more of the following objectives: (1) to provide data on groundwater quality near suspected sources of contamination; (2) to informally monitor groundwater quality near known sources of contamination to determine extent of contaminant migration or change in concentration of contaminants; and (3) to provide data on groundwater quality on a regional scale or topical issue, including naturally occurring constituents that may pose a health risk. The emphasis of the groundwater-quality monitoring program primarily has been spatial rather than temporal assessment.

Chester County covers $760 \mathrm{mi}^{2}$ in southeastern Pennsylvania, and its population relies partly on groundwater for drinking-water supply. The rocks underlying Chester County form fractured-rock aquifers, where the competent bedrock is overlain by weathered bedrock (saprolite) and soil, and these aquifers are recharged locally by precipitation. Land use in the Chester County is mixed, consisting largely of different types of agriculture (such as row crops, hay, mushroom growing and composting, nurseries, orchards, and dairy) with lesser amounts of wooded, residential, industrial, commercial, and other uses. On-site wastewater disposal and individual wells for water supply are common. Most wells sampled for the groundwater monitoring program were residential wells, although some public supply, industrial, commercial, and monitor wells were also sampled.

Generally, chemical constituents associated with various land uses and human activities were measured in groundwater near those areas in Chester County. Results of the groundwater-quality monitoring program included:

- Volatile organic compounds (VOCs) were detected near some uncontrolled landfills, dumps, and industrial waste-disposal activities. Trichloroethylene (TCE) was the most frequently detected VOC. Concentrations of TCE also exceeded the Maximum Contaminant Level (MCL) in drinking water most frequently and were at or above the MCL of $5 \mu \mathrm{g} / \mathrm{L}$ in samples from 47 of 412 wells sampled from 1980 through 2001 . The highest measured TCE concentration was $4,400 \mu \mathrm{g} / \mathrm{L}$. Concentrations of several other VOCs exceeded MCLs established for those compounds in samples from fewer than 47 wells sampled as part of the monitoring program.

- Elevated concentrations of ammonia, iron, and manganese were measured in groundwater and stream base flow near some uncontrolled dumps and landfills.

- Concentrations of chloride (up to $350 \mathrm{mg} / \mathrm{L}$ ) substantially above the estimated natural background concentration of $10 \mathrm{mg} / \mathrm{L}$ were measured in groundwater near salt piles and the Pennsylvania Turnpike and are related to the use of deicing salts on roads.

- Formaldehyde in concentrations above drinking-water health advisories of $1 \mathrm{mg} / \mathrm{L}$ were measured in groundwater near cemeteries.

- Pesticides and elevated concentrations of nitrate (up to $45 \mathrm{mg} / \mathrm{L}$ as N) were detected in groundwater and base flow in some agricultural areas of the county, including near row crops, orchards, nurseries, and mushroomgrowing operations. Samples from the Octoraro Creek Basin showed that relatively high concentrations of nitrate and some pesticides such as atrazine in base flow occur where high concentrations of these constituents were found in groundwater.

- In areas where the relation between groundwater and surface-water quality were investigated, base-flow samples indicated that groundwater discharge to streams carries contaminants such as nitrate, pesticides, chloride, and wastewater compounds. Conversely, in streams with losing reaches, contaminants in surface water may enter the groundwater system. 
- Moderately elevated concentrations (compared to estimated natural background) of nitrate (commonly 3-6 mg/L as N), chloride, and boron and relatively low concentrations of VOCs and other anthropogenic wastewater compounds, including pharmaceuticals, were measured in groundwater and base flow in areas with residential on-site wastewater disposal, indicating that constituents from wastewater affect the quality of groundwater and stream base flow.

- At least half of the sampled wells in the county had chloride concentrations above the natural background level of about $10 \mathrm{mg} / \mathrm{L}$. Chloride concentrations greater than the SMCL of $250 \mathrm{mg} / \mathrm{L}$ were measured in samples from 5 wells and were up to $2,100 \mathrm{mg} / \mathrm{L}$. Sources of chloride included deicing salts on roads and on-site wastewater disposal.

- Trends in groundwater quality estimated from baseflow samples and from review of well-water samples indicated that chloride concentrations have been increasing in groundwater and base flow through time since the 1960s as urbanization of the county increased. Other effects of urbanization, such as introduction of other chemicals used at the land surface in urban areas (such as VOCs), on groundwater quality are possible and have been documented through the program.

Data on naturally occurring constituents in groundwater that may pose a risk to human health were also collected through the groundwater-quality monitoring program. These naturally occurring constituents are derived mainly from rocks and soils that form the fractured-rock aquifers in the county. Chester County has relatively complex geology, with about 40 different mapped bedrock units consisting of Paleozoicage and older metamorphic rocks, including phyllite, schist, limestone, marble, quartzite, and gneiss, and Mesozoic-age sedimentary (Triassic age) and intrusive (Triassic- and Jurassic-age) rocks. The naturally occurring constituents in groundwater in Chester County that may be of concern include:

- Radionuclides-radium-226, radium-228, radium-224, gross alpha-particle activity-especially in groundwater from quartzite aquifers with low $\mathrm{pH}-$ and radon-222 in many geologic units throughout the county.

- Arsenic, especially in groundwater from shales and other Triassic-age rocks in northern Chester County.

- Lead in low $\mathrm{pH}$ water.

Activities of radium-226, radium-228, and gross alpha particles were measured in reconnaissance sampling of geologic units in the county from 1985 through 1987. Subsequent studies by USGS in cooperation with state agencies showed that 62 percent of well-water samples in the Chickies Quartzite had combined radium-226 plus radium-228 activities greater than the USEPA MCL of $5 \mathrm{pCi} / \mathrm{L}$. Elevated radium and gross alpha-particle activities are associated with low $\mathrm{pH}$ in groundwater in the Chickies Quartzite. Elevated radium activities were also found in groundwater in other Paleozoicage quartzites and occasionally in other geologic units, including limestones, in the county. Follow-up sampling in 1999 and 2003-06 confirmed earlier findings of elevated radium and gross alpha-particle activities in the Chickies Quartzite and also identified the presence of other short-lived radionuclides radium-224 and lead-210. The radium-224 activity of $265 \mathrm{pCi} / \mathrm{L}$ measured in a well-water sample collected in 1999 in Chester County is one of the highest reported in the United States. The difference between the gross alpha-particle activity at 72 hours and 30 days measured in 18 samples ranged up to a factor of 7 and showed that short-lived radionuclides are present in groundwater. The use of gross alpha-particle activity measurements at 30 days may be insufficient to monitor potential exceedances of MCLs in some settings.

Radon-222 activities above the higher proposed MCL of $4,000 \mathrm{pCi} / \mathrm{L}$ occurred in about 18 percent of 605 wells sampled throughout the county from 1986 through 2000 and were most common in samples from wells in the Peters Creek Schist. Water samples collected monthly for radium and radon analysis showed seasonal fluctuations that indicate drinkingwater standards in groundwater could be exceeded seasonally but might not be detected if the well were not sampled during the time of year when maximum concentrations occur.

Arsenic concentrations greater than the MCL of $10 \mu \mathrm{g} / \mathrm{L}$ have been measured in only a few wells in the county, but higher concentrations of arsenic are more common in the Triassic-age geologic units (mostly shales and sandstones) than elsewhere in the county. Other studies estimate that about 10 percent of the wells in similar rocks in nearby Bucks and Montgomery Counties have water with arsenic concentrations greater than $10 \mu \mathrm{g} / \mathrm{L}$. Concentrations of arsenic greater than the health advisory level of $2 \mu \mathrm{g} / \mathrm{L}$ were present in about 40 percent of the well-water samples in the Triassic geologic units and in about 10 percent or less of well-water samples in other geologic units in Chester County.

Other potential natural hazards, such as lead, were measured infrequently in concentrations in well water above drinking-water standards (less than 10 percent of samples). Some lead may occur naturally, although lead also may have anthropogenic sources in plumbing. Lead from either source may be more soluble in some types of water. In the relatively acidic groundwater in quartzite, lead concentrations appear to increase with a decrease in $\mathrm{pH}$.

Through the Chester County groundwater-quality monitoring program, groundwater contamination from localized targeted sources was identified and data on the effects of some land uses, including residential on-site wastewater disposal, on groundwater and base-flow quality were collected. Although the primary focus of the monitoring program was spatial assessment of groundwater-quality issues and concerns, the data collected through the program may serve as a baseline for future comparison. Additional analysis or collection of groundwater-quality data may be helpful in determining specific land-use or geochemical factors affecting groundwater quality spatially or through time. 


\section{References Cited}

Blackmer, G.C., 2004a, Bedrock geology of the Coatesville quadrangle, Chester County, Pennsylvania: Pennsylvania Geological Survey, 4th ser., Atlas 189b, 16 p., 2 pls., scale 1:24,000, 5 datasets, bedrock geol. map, CD-ROM.

Blackmer, G.C., 2004b, Bedrock geologic map of the Pennsylvania portion of the Kennett Square quadrangle, Chester County, Pennsylvania: Pennsylvania Geological Survey, 4th ser., Open-File Report OFBM 04-01.0, 14 p., Portable Document Format (PDF).

Blackmer, G.C., 2005, Preliminary bedrock geologic map of a portion of the Wilmington 30 - by 60 -minute quadrangle, southeastern Pennsylvania: Pennsylvania Geological Survey, 4th ser., Open-File Report OFBM 05-01.0, 16 p., Portable Document Format (PDF).

Blackmer, G.C., and Brown, C.H., 2006, Bedrock geologic map of the Parkesburg quadrangle, Chester and Lancaster Counties, Pennsylvania: Pennsylvania Geological Survey, 4th ser., Open-File Report OFBM 06-03.0, 13 p., Portable Document Format (PDF).

Bosbyshell, Hal, 2006, Bedrock Geologic Map of the Chester Valley and Piedmont Portion of the Germantown, Malvern, Norristown, and Valley Forge Quadrangles, Chester, Delaware, Montgomery, and Philadelphia Counties, Pennsylvania: Pennsylvania Geological Survey, 4th ser., Open-File Report OFBM 06-04.0, 16 p., Portable Document Format (PDF).

Brown, C.H., 2006, Bedrock geologic map of the Honey Brook quadrangle, Chester and Lancaster Counties, Pennsylvania: Pennsylvania Geological Survey, 4th ser., OpenFile Report OFBM 06-02.0, 11 p., Portable Document Format (PDF).

Chester County Water Resources Authority, 2002, Watersheds, an integrated water resources management plan for Chester County, Pennsylvania and its watersheds: West Chester, Pa., accessed November 20, 2009, at http://dsf.chesco.org/ water/cwp/view.asp? $a=3 \& q=610690$.

Chester Water Authority, 2008, Chester Water Authority Water Quality Report calendar year 2008: accessed June 2, 2009, at http://www.chesterwater.com/waterqualityrep/water\%20 quality\%20report.htm.

Cinotto, P.J., Reif, A.G., and Olson, L.E., 2005, Environmental setting, water budget, and stream assessment for the Broad Run Watershed, Chester County, Pennsylvania: U.S. Geological Survey Scientific Investigations Report 2005-5156, $59 \mathrm{p}$.
Delaware Valley Regional Planning Commission, 2001, 19802000 Census population by minor civil division (28-county service area): Delaware Valley Regional Planning Commission Regional Data Bulletin no. 67, December 2001.

Delaware Valley Regional Planning Commission, 2004, 2000 Land use by minor civil division 9- county DVRPC region: Delaware Valley Regional Planning Commission Regional Data Bulletin no. 78, March 2004.

Delaware Valley Regional Planning Commission, 2007, Regional, county, and municipal population and employment forecasts, 2005-2035: Delaware Valley Regional Planning Commission Analytical Data Report no. 14, August 2007.

Delaware Valley Regional Planning Commission, 2008, Land use in the Delaware Valley 2005: Delaware Valley Regional Planning Commission Analytical Data Report no. 16, July 2008.

Delaware Valley Regional Planning Commission, 2009, Chester County profile, 2005 land use: accessed September 24, 2009, at http://www.dvrpc.org/asp/CountyProfiles/Chester.aspx.

Deutsch, W.J., 1998, Groundwater geochemistry. Fundamentals and application to contamination: Boca Raton, Fla., CRC Press, $232 \mathrm{p}$.

Durlin, R.R., and Schaffstall, W.P., 1999, Water resources data Pennsylvania water year 1998, volume 1. Delaware River Basin: U.S. Geological Survey Water-Data Report PA-98-1, $405 \mathrm{p}$.

Durlin, R.R., and Schaffstall, W.P., 2001a, Water resources data Pennsylvania water year 2000, volume 1. Delaware River Basin: U.S. Geological Survey Water-Data Report PA-00-1, 652 p.

Durlin, R.R., and Schaffstall, W.P., 2001b, Water resources data Pennsylvania water year 2000, volume 2. Susquehanna and Potomac River Basins: U.S. Geological Survey WaterData Report PA-00-1, 458 p.

Durlin, R.R., and Schaffstall, W.P., 2002, Water resources data Pennsylvania water year 2001, volume 1. Delaware River Basin: U.S. Geological Survey Water-Data Report PA-01-1, 529 p.

Durlin, R.R., and Schaffstall, W.P., 2003, Water resources data Pennsylvania water year 2002, volume 1. Delaware River Basin: U.S. Geological Survey Water-Data Report PA-02-1, $527 \mathrm{p}$.

Durlin, R.R., and Schaffstall, W.P., 2005, Water resources data Pennsylvania water year 2004, volume 1. Delaware River Basin: U.S. Geological Survey Water-Data Report PA-04-1, $651 \mathrm{p}$. 
Durlin, R.R., Schaffstall, W.P., and Beaver, M.R., 2006, Water resources data Pennsylvania water year 2005, volume 1 . Delaware River basin: U.S. Geological Survey Water-Data Report PA-05-1, $575 \mathrm{p}$.

Focazio, M.J., Szabo, Zoltan, Kraemer, T.F., Mullin, A.H., Barringer, T.H., and DePaul, V.T., 2001, Occurrence of selected radionuclides in groundwater used for drinking water in the United States-A reconnaissance study, 1998: U.S. Geological Survey Water-Resources Investigations Report 00-4273, 40 p.

Health Canada, 2008, Guidelines for Canadian Drinkingwater quality summary table prepared by FederalProvincial-Territorial Committee on Drinking Water of the Federal-Provincial-Territorial Committee on Health and the Environment, May 2008: accessed October 28, 2008, at http://www.hc-sc.gc.calewh-semt/alt_formats/ hecs-sesc/pdf/pubs/water-eau/sum_guide-res_recom/ summary-sommaire-eng.pdf.

Hem, J.D., 1985, Study and interpretation of the chemical characteristics of natural water: U.S. Geological Survey Water-Supply Paper 2254, 263 p.

Hill, J.C., 2006, Bedrock geologic map of the Oxford and Pennsylvania portion of the Bay View quadrangles, Chester and Lancaster Counties, Pennsylvania: Pennsylvania Geological Survey, 4th ser., Open-File Report OFBM 06-01.0, 12 p., Portable Document Format (PDF).

Kunkle, W.M., 1963, Soil survey of Chester and Delaware Counties, Pennsylvania: Soil Conservation Service Soil Survey series 1959, no. 19, 124 p.

Lindsey, B.D., Rasberry, J.S., and Zimmerman, T.M., 2002, Microbiological quality of water from noncommunity supply wells in carbonate and crystalline rock aquifers of Pennsylvania: U.S. Geological Survey Water-Resources Investigations Report 01-4268, 30 p.

Ludlow, R.A., and Loper, C.A., 2004, Chester County groundwater atlas, Chester County, Pennsylvania: U.S. Geological Survey Open-File Report 03-442, 85 p.

Marquez, L.L., 2005, Map of the bedrock geology, Wagontown quadrangle, Chester County, Pennsylvania: Pennsylvania Geological Survey, 4th ser., Open-File Report OFBM 05-05.0, 6 p., Portable Document Format (PDF).

McConnell, L.L., Harman-Fetcho, J.A., and Hagy, J.D., III, 2004, Measured concentrations of herbicides and model predictions of atrazine fate in the Patuxent River estuary: Journal of Environmental Quality, v. 33, no. 2, p. 594-604.
Mullaney, J.R., Lorenz, D.L., and Arnston, A.D., 2009, Chloride in groundwater and surface water in areas underlain by the glacial aquifer system, northern United States: U.S. Geological Survey Scientific Investigations Report 20095086, $41 \mathrm{p}$.

National Oceanic and Atmospheric Administration, 2005, Climactic data, annual summary, Pennsylvania, 2005: National Climactic Data Center, v. 110, no. 13.

Reif, A.G., 2002a, Assessment of stream conditions and trends in biological and water-chemistry data from selected streams in Chester County, Pennsylvania, 1981-97: U.S. Geological Survey Water-Resources Investigations Report $02-4242,77 \mathrm{p}$.

Reif, A.G., 2002b, Assessment of stream conditions using biological indices at selected sites the Big Elk and Octoraro Creek Basins, Chester County, Pennsylvania, 1981-97: U.S. Geological Survey Water-Resources Fact Sheet FS-115-02, 4 p.

Schreffler, C.L., Galeone, D.G., Veneziale, J.M., Olson, L.E., and O'Brien, D.L., 2005, Effects of spray-irrigated treated effluent on water quantity and quality, and the fate and transport of nitrogen in a small watershed, New Garden Township, Chester County, Pennsylvania: U.S. Geological Scientific Investigations Report 2005-5043, 158 p.

Senior, L.A., 1996, Groundwater quality and its relation to hydrogeology, land use, and surface-water quality in the Red Clay Creek Basin, Piedmont Physiographic Province, Pennsylvania and Delaware: U.S. Geological Survey Water-Resources Investigations Report 96-4288, 122 p.

Senior, L.A., 1998, Radon-222 in the groundwater of Chester County, Pennsylvania: U.S. Geological Survey WaterResources Investigations Report 98-4169, 79 p.

Senior, L.A., and Cinotto, P.J., 2007, Effect of on-site wastewater disposal on quality of groundwater and base flowA pilot study in Chester County, Pennsylvania, 2005: U.S. Geological Survey Open-File Report 2007-1253, 50 p.

Senior, L.A., and Koerkle, E.H., 2003, Simulation of streamflow and water quality in the Christina River subbasin and overview of simulations in other subbasins of the Christina River basin, Pennsylvania, Maryland, and Delaware: U.S. Geological Survey Water-Resources Investigations Report 03-4193, 144 p.

Senior, L.A., and Sloto, R.A., 2000, Radium-224 and its relation to gross-alpha-particle, radium-226, and radium-228 activities in groundwater from the rocks of the Piedmont physiographic province, southeastern Pennsylvania: Geological Society of America Abstracts with Programs, v. 32, no. 1, p. 73 . 
Senior, L.A., and Sloto, R.A., 2006, Arsenic, boron, and fluoride concentrations in groundwater in and near diabase intrusions, Newark Basin, southeastern Pennsylvania: U.S. Geological Survey Scientific Investigations Report 2006-5261, $105 \mathrm{p}$.

Senior, L.A., Sloto, R.A., and Reif, A.G., 1997, Geohydrology and water quality, West Valley Creek Basin, Chester County, Pennsylvania: U.S. Geological Survey Water-Resources Investigations Report 94-4137, 160 p.

Senior, L.A., and Vogel, K.L., 1995, Radium and radon in the groundwater in the Chickies Quartzite, southeastern Pennsylvania: U.S. Geological Survey Water-Resources Investigations Report 92-4088, 145 p.

Serfes, M.E., 2006, Arsenic occurrence, sources, mobilization and transport in the Passaic and Lockatong Formations of the Newark Basin: Geological Society of America Abstracts with Programs, v. 38, no. 2, p. 63, March 2006.

Serfes, M.E., and Spayd, Steven, 2006, Arsenic occurrence, sources, mobilization and treatment in the Newark Basin in New Jersey: Geological Society of America Abstracts with Programs, v. 38, no. 7, p. 135, October 2006.

Sloto, R.A., 1987, Effect of urbanization on the water resources of eastern Chester County, Pennsylvania: U.S. Geological Survey Water-Resources Investigations Report 87-4098, $131 \mathrm{p}$.

Sloto, R.A., 1989, Selected groundwater data, Chester County, Pennsylvania: U.S. Geological Survey Open-File Report 87-0217, 198 p., 2 sheets, scale 1:50,000.

Sloto, R.A., 1990, Geohydrology and simulation of groundwater flow in the carbonate rocks of the Valley Creek basin, eastern Chester County, Pennsylvania: U.S. Geological Survey Water-Resources Investigations Report 89-4169, $60 \mathrm{p}$.

Sloto, R.A., 1994, Geology, hydrology, and groundwater quality of Chester County, Pennsylvania: Chester County Water Resources Authority Water Resource Report 2, 127 p.

Sloto, R.A., 1997, Hydrogeologic investigation of the Malvern TCE Superfund Site, Chester County, Pennsylvania: U.S. Geological Survey Water-Resources Investigations Report 96-4286, $124 \mathrm{p}$.

Sloto, R.A., 2000, Naturally occurring radionuclides in the groundwater of southeastern Pennsylvania: U.S. Geological Survey Fact Sheet FS-012-00, 8 p.

Sloto, R.A., 2001, Evaluation of borehole geophysical logs and hydraulic tests, Phase III, at AIW Frank/Mid-County Mustang Superfund site, Chester County, Pennsylvania: U.S. Geological Survey Water-Resources Investigations Report 01-4004, 33 p.
Sloto, R.A., 2002, Hydrogeology and groundwater quality, Big Elk Creek Basin, Chester County, Pennsylvania and Cecil County, Maryland: U.S. Geological Survey WaterResources Investigations Report 02-4057, 81 p.

Spongberg, A.L., and Becks, P.M., 2000, Inorganic soil contamination from cemetery leachate: Water, Air, and Soil Pollution, v. 117, p. 313-327.

Stamer, J.K., Yorke, T.H., and Pederson, G.L., 1985, Distribution and transport of trace substances in the Schuylkill River basin from Berne to Philadelphia, Pennsylvania: U.S. Geological Survey Water-Supply Paper 2256-A, A45p.

U.S. Geological Survey, variously dated, National field manual for the collection of water-quality data: U.S. Geological Survey Techniques of Water-Resources Investigations, book 9, chaps. A1-A9, available online at http://pubs.water.usgs.gov/twri9A.

U.S. Geological Survey, 2006, Water table maps for Chester County, Pennsylvania: accessed November 25, 2008, at http://pa.water.usgs.gov/chesco/water_table_mapping.html.

U.S. Geological Survey, 2007, Water-resources data for the United States, water year 2006: U.S. Geological Survey Water-Data Report WDR-US-2006, accessed September 22, 2008, at http://pubs.water.usgs.gov/wdr2007.

U.S. Geological Survey, 2008, Water-resources data for the United States, water year 2007: U.S. Geological Survey Water-Data Report WDR-US-2007, accessed September 22, 2008, at http://pubs.water.usgs.gov/wdr2007.

U.S. Geological Survey, 2009, Water-resources data for the United States, water year 2008: U.S. Geological Survey Water-Data Report WDR-US-2008, accessed October 26, 2009, at http://wdr.water.usgs.gov/wy2008.

U.S. Environmental Protection Agency, 1999, Revisions to the Unregulated Contaminants Monitoring Regulation for Public Water Systems, CFR Parts 9, 141 and 142: Federal Register September 17, 1999, v. 64, no. 180, p. 50555-50620.

U.S. Environmental Protection Agency, 2009a, 2009 edition of the drinking water standards and health advisories: U.S. Environmental Protection Agency EPA 822-R-09-011, 12 p.

U.S. Environmental Protection Agency, 2009b, Mid-Atlantic Correction Action RCRA Facilities-Pennsylvania: last updated June 30, 2009, accessed July 2, 2009, at http://www.epa.gov/reg3wcmd/ca/pa.htm.

U.S. Environmental Protection Agency, 2009c, MidAtlantic Superfund, Recticon/Allied Steel Corporation current site information: last updated April 17, 2009, accessed June 2, 2009, at http://www.epa.gov/reg3hwmd/npl/PAD002353969.htm. 
Wiswall, C.G., 2005, Bedrock geologic map of the Unionville quadrangle, Chester County, Pennsylvania: Pennsylvania Geological Survey, 4th ser., Open-File Report OFBM 05-03.0, 15 p., Portable Document Format (PDF). 

Appendix 1.

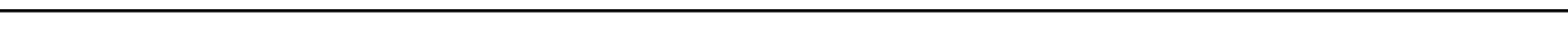






Figure 1-1. Municipalities in Chester County, $\mathrm{Pa}$. 


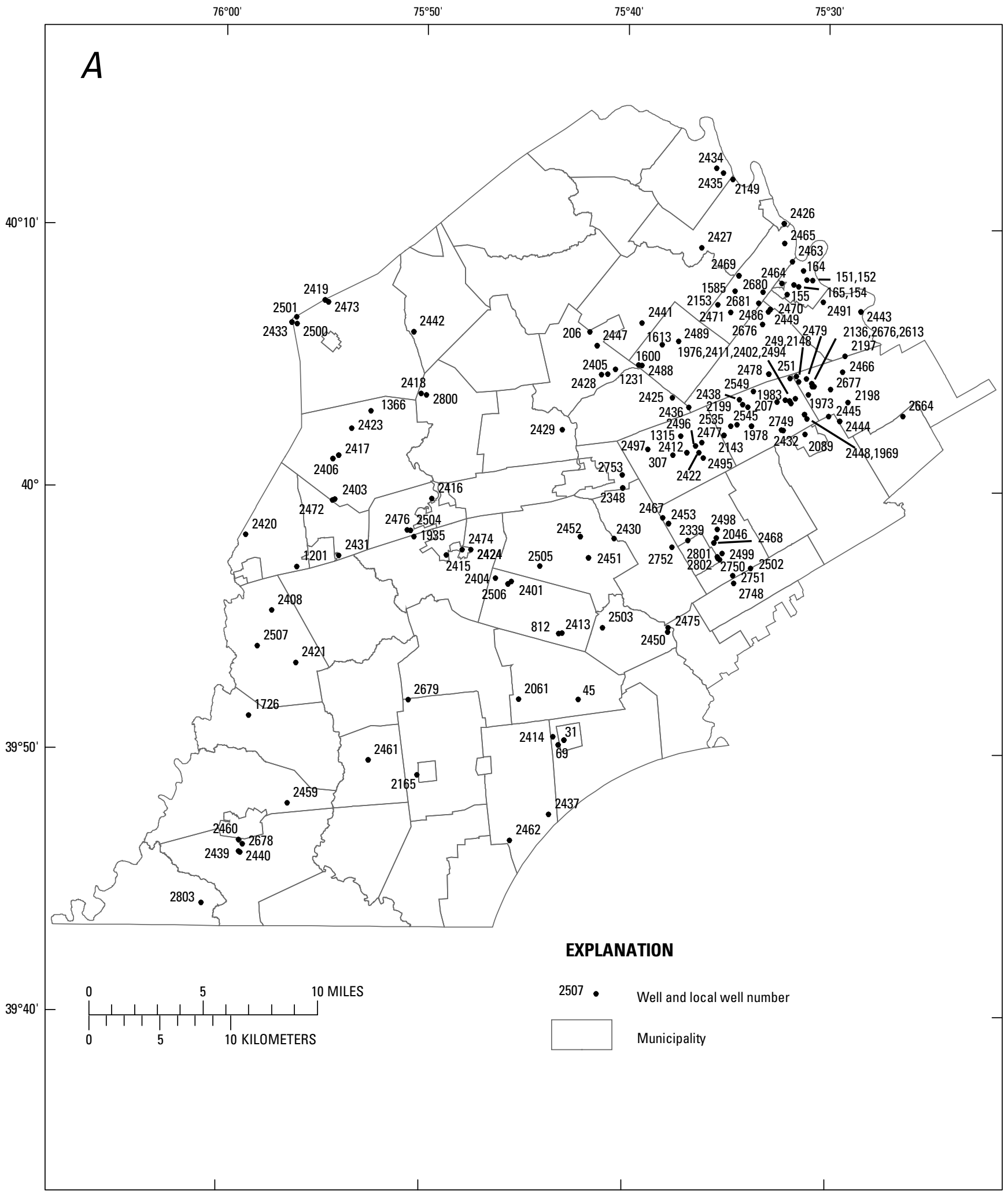

Figure 1-2. Location of wells and surface-water sites sampled for the Chester County groundwater-quality monitoring program, (A) 1980-84, (B) 1985-89, (C) 1990-94, (D) 1995-1999, (E) 2000-04, and (F) 2005-2008. 


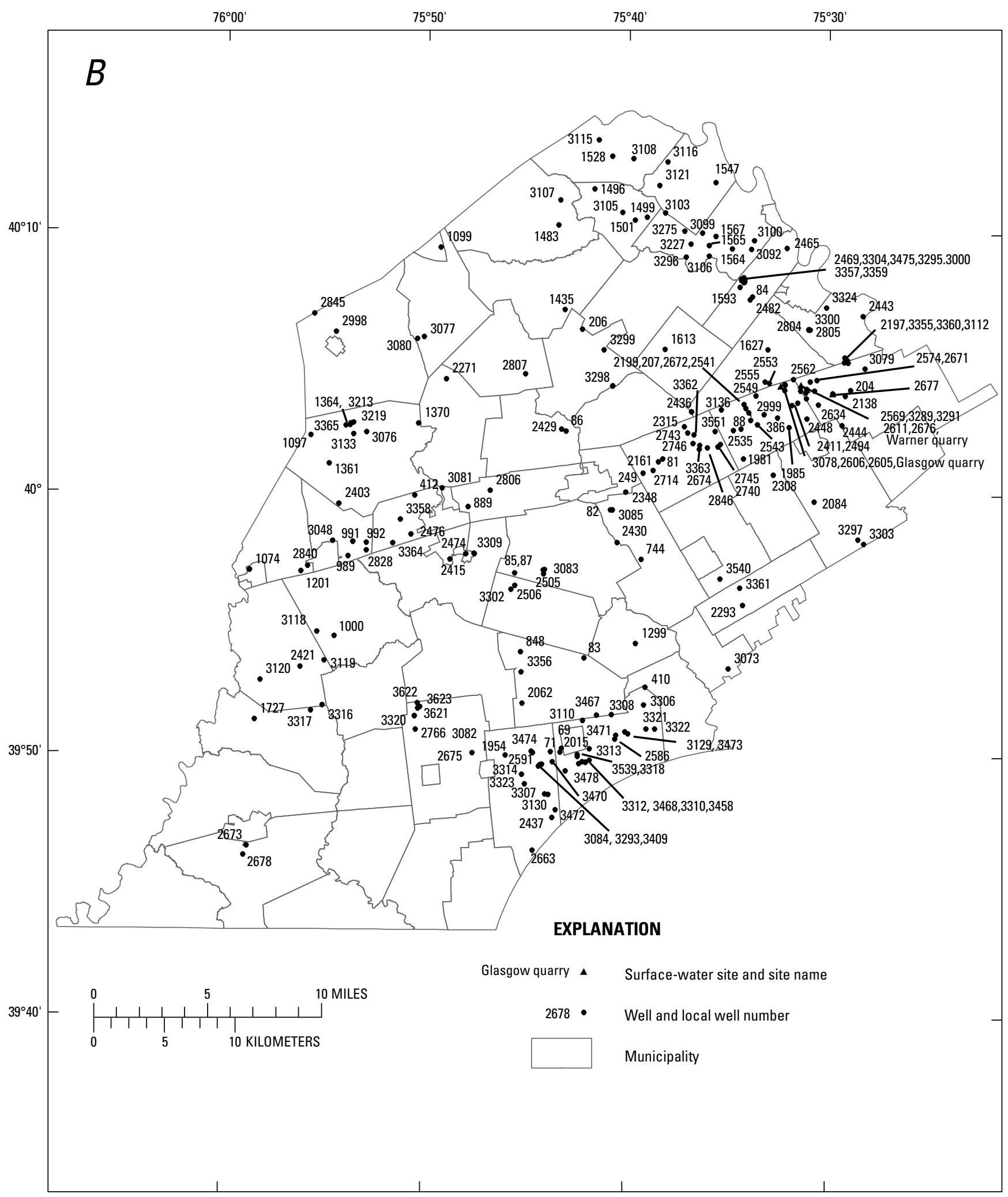

Figure 1-2. Location of wells and surface-water sites sampled for the Chester County groundwater-quality monitoring program, (A) 1980-84, (B) 1985-89, (C) 1990-94, (D) 1995-99, (E) 2000-04, and (F) 2005-08.-Continued 


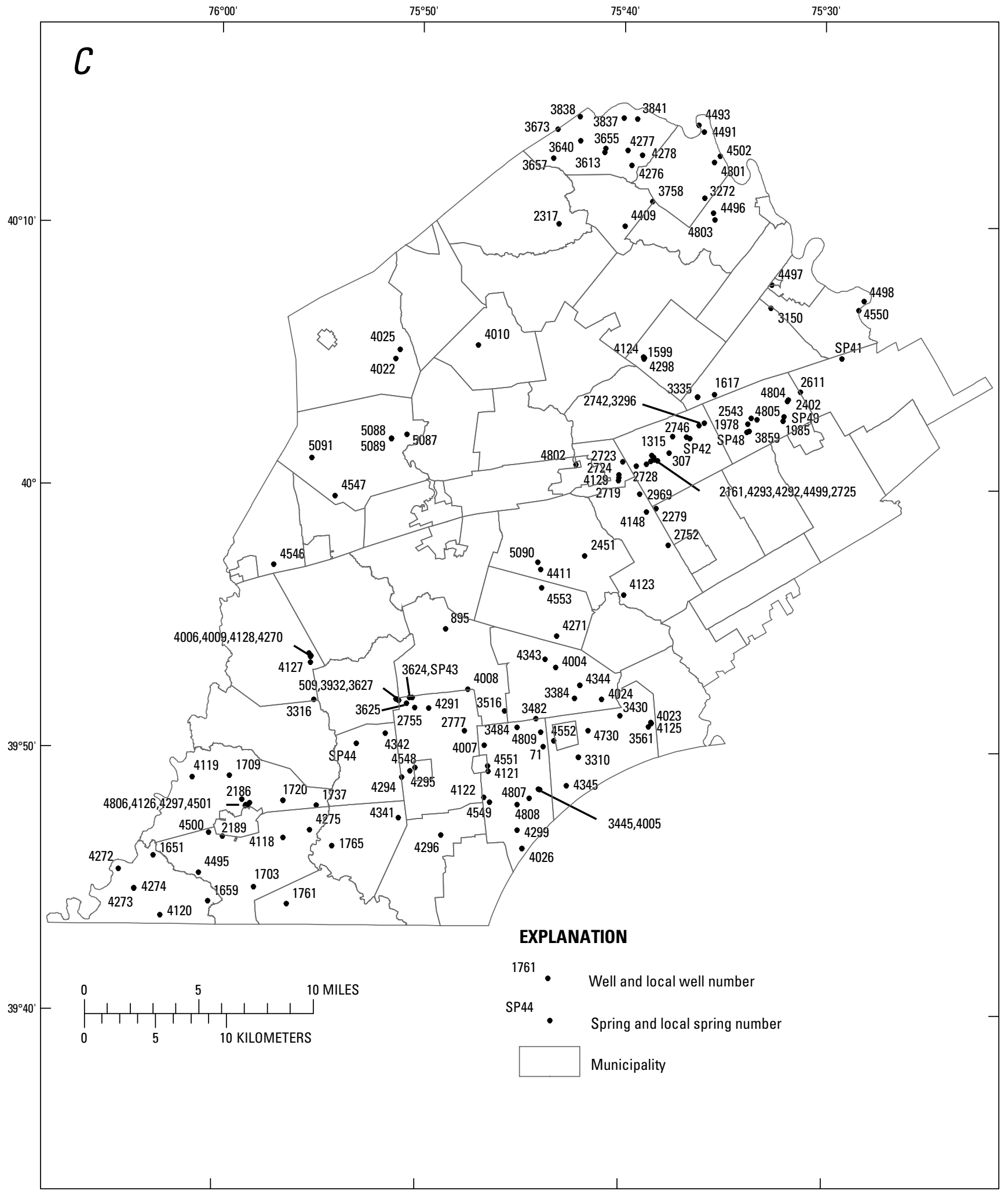

Figure 1-2. Location of wells and surface-water sites sampled for the Chester County groundwater-quality monitoring program, (A) 1980-84, (B) 1985-89, (C) 1990-94, (D) 1995-99, (E) 2000-04, and (F) 2005-08.-Continued 


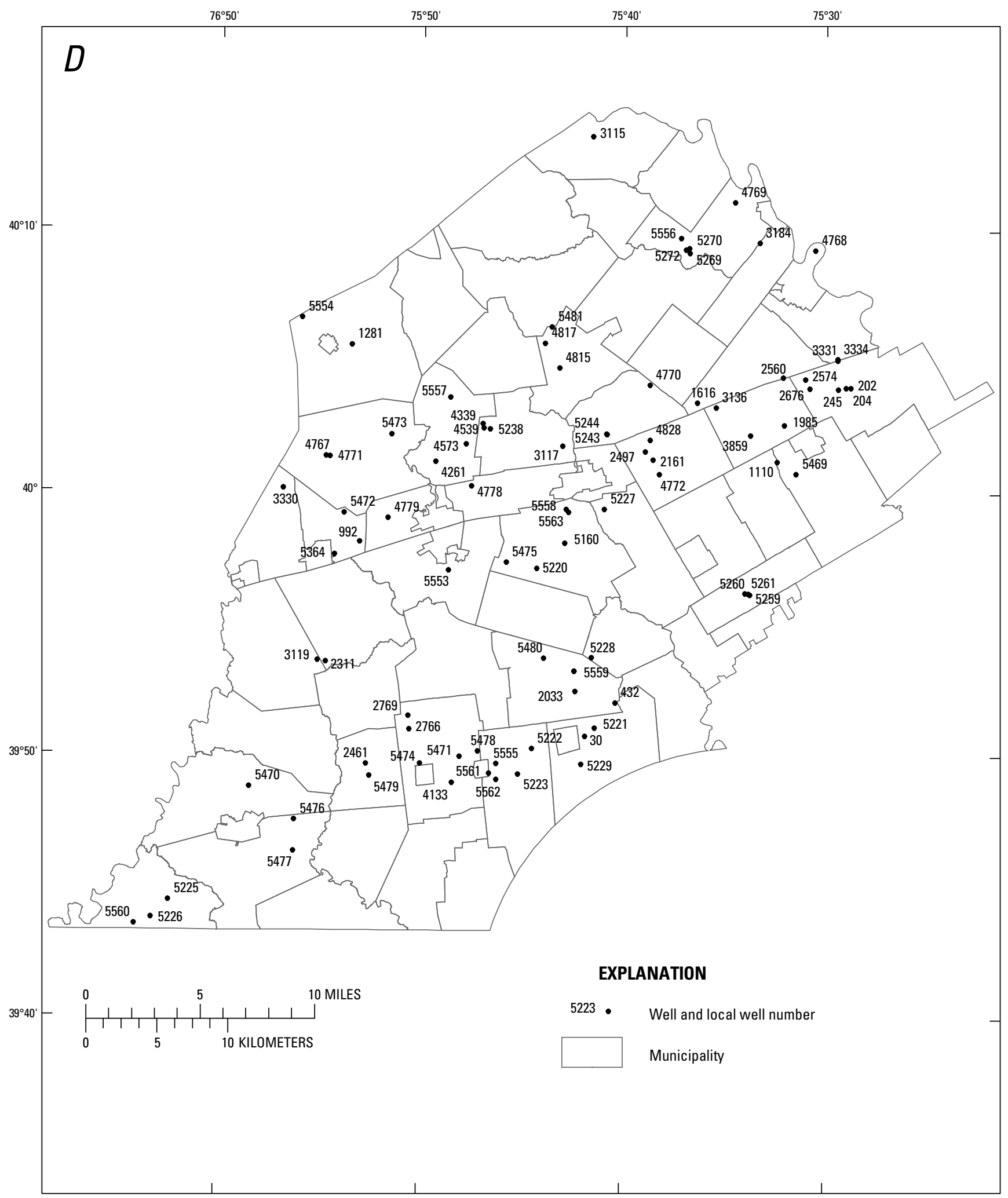

Figure 1-2. Location of wells and surface-water sites sampled for the Chester County groundwater-quality monitoring program, (A) 1980-84, (B) 1985-89, (C) 1990-94, (D) 1995-99, (E) 2000-04, and (F) 2005-08.-Continued 


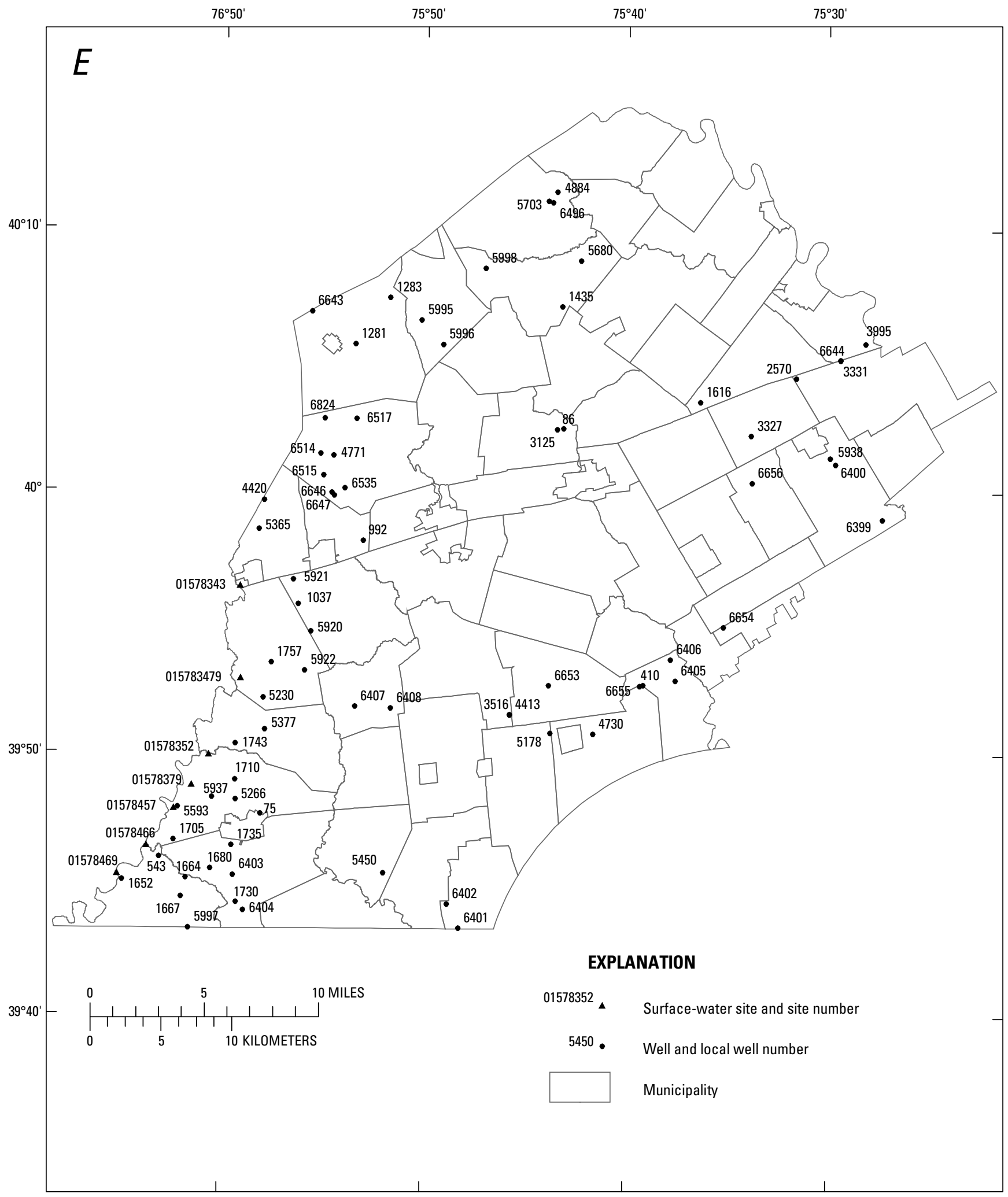

Figure 1-2. Location of wells and surface-water sites sampled for the Chester County groundwater-quality monitoring program, (A) 1980-84, (B) 1985-89, (C) 1990-94, (D) 1995-99, (E) 2000-04, and (F) 2005-08.-Continued 


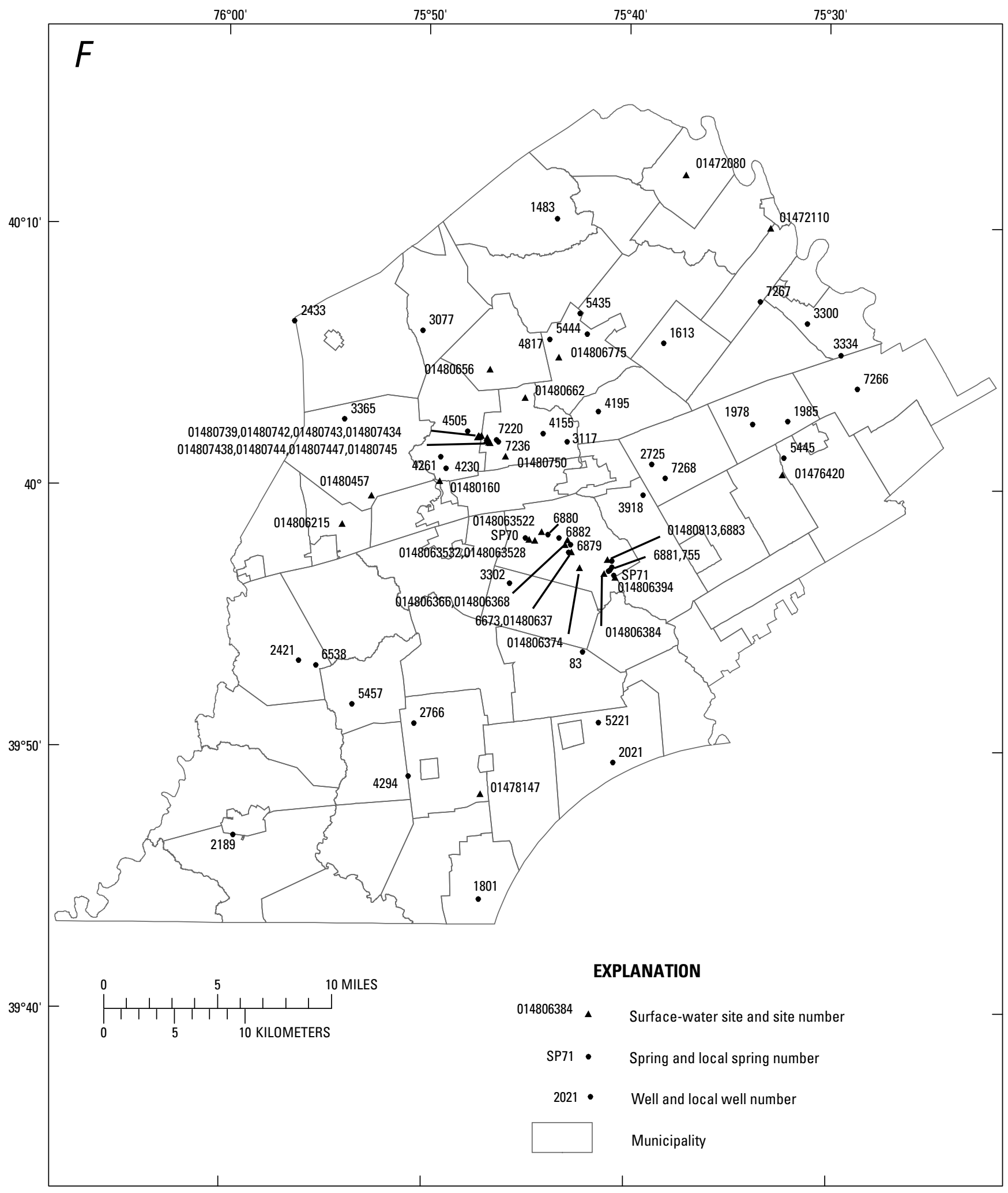

Figure 1-2. Location of wells and surface-water sites sampled for the Chester County groundwater-quality monitoring program, (A) 1980-84, (B) 1985-89, (C) 1990-94, (D) 1995-99, (E) 2000-04, and (F) 2005-08.-Continued 
Table 1-1. List of wells and streams sampled by year and summary of water-quality-sampling results for the Chester County groundwater-quality monitoring program, 1980-2008.

[Municipalities are shown on figure 1.1, and locations of wells and streams are shown on figure 1-2]

Abbreviations-

Local well number: $\mathrm{CH}-$, where prefix $\mathrm{CH}$ designates Chester County; SP designates spring;

Gunit, geologic unit code:

\begin{tabular}{|c|c|}
\hline 000ANRS & anorthosite \\
\hline 000GRGS & granite gneiss \\
\hline 000MFCGH & mafic gneiss, amphibolite facies \\
\hline 000MFCGP & mafic gneiss, granulite facies \\
\hline 000PGMT & pegmatite \\
\hline 000QZMZ & quartz monzonite and quartz monzonite gneiss \\
\hline 000SRPN & serpentinite \\
\hline 112ALVM & alluvium \\
\hline 231BRCK & Brunswick Group \\
\hline 231DIBS & diabase \\
\hline 231HMCK & Hammer Creek Formation \\
\hline 231LCKG & Lockatong Formation \\
\hline 231SCKN & Stockton Formation \\
\hline $300 \mathrm{CCKV}$ & Cockeysville Marble \\
\hline 300PRCK & Peters Creek Schist \\
\hline 300STRS & Setters Quartzite \\
\hline 300WSCK & Wissahickon Formation \\
\hline 300WSCKA & Octoraro Formation \\
\hline 300WSCKO & Wissahickon Formation \\
\hline $367 \mathrm{CNSG}$ & Conestoga Limestome \\
\hline 371ELBK & Elbrook Limestone \\
\hline 377AMHP & Anietam/Harpers, undifferntiated \\
\hline 377ANTM & Antietam Formation \\
\hline 377CCKS & Chickies Quartzite \\
\hline 377HLLM & Hellam Conglomerate \\
\hline 377HRPR & Harpers Formation \\
\hline $377 \mathrm{KZRS}$ & Kinzers Limestone \\
\hline 377LDGR & Ledger Dolomite \\
\hline 377VNTG & Vintage Dolomite \\
\hline 400BMFGA & banded mafic gneiss, amphibolite facies \\
\hline 400FCIGA & felsic and intermediate gneiss, amphibolite facies \\
\hline 400FLCGA & felsic gneiss, amphibolite facies \\
\hline 400FLCGG & felsic gneiss, granulite facies \\
\hline 400FLCGH & felsic gneiss, amphibolite facies \\
\hline 400FLCGP & felsic gneiss, granulite facies \\
\hline 400FMFG & felsic and mafic gneiss \\
\hline 400GPCGA & graphitic felsic gneiss, amphibolite facies \\
\hline 400GPCGG & graphitic felsic gneiss, granulite facies \\
\hline 400MFCGH & mafic gneiss, amphibolite facies \\
\hline
\end{tabular}

Reason sampled: $\quad$ DU, dump or landfill; IPT, industry or localized (point) source; LU, land use; NA, natural

Man-made organic compound: $\quad x$ indicates man-made organic compound detected; MCL or HA, maximum contaminant level or health advisory for drinking water exceeded for constituent by category, where $\mathrm{m}$ indicates MCL exceeded and h indicates HA exceeded: (Note that row is shaded green if MCL or HA exceeded); VOC, volatile organic compound or other industrial compound; Pesticide, herbicide or insecticide; Nutrient, nitrate or nitrite; Metal, metal or other inorganic ion; Radchem, any radiochemical constituent except radon-222 


\section{Groundwater-Quality Monitoring Program in Chester County, Pennsylvania, 1980-2008}

Appendix 1. List of wells and streams sampled by year and summary of water-quality-sampling results for the Chester County groundwater-quality monitoring program, 1980-2008.-Continued

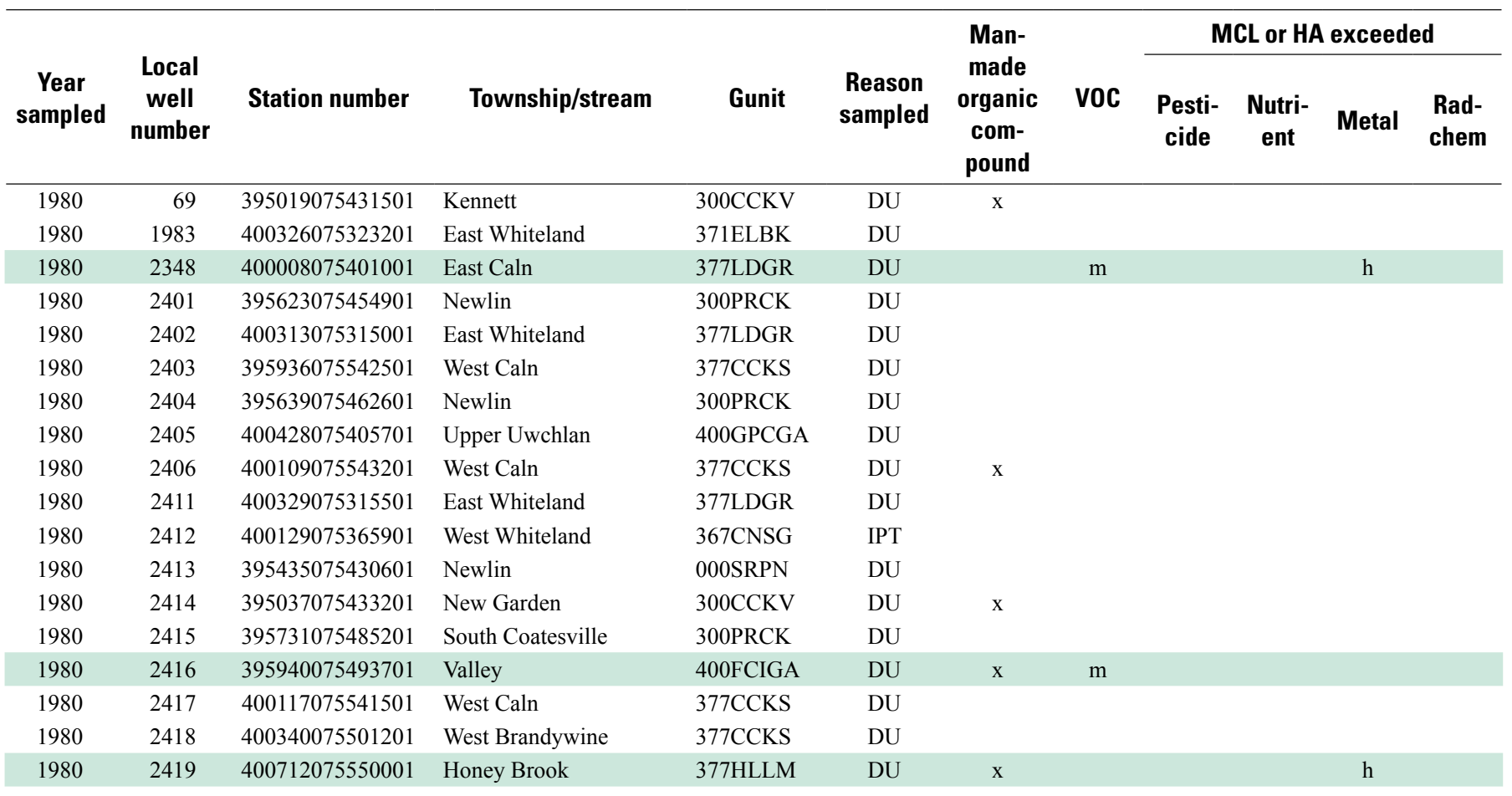


Appendix 1. List of wells and streams sampled by year and summary of water-quality-sampling results for the Chester County groundwater-quality monitoring program, 1980-2008.-Continued

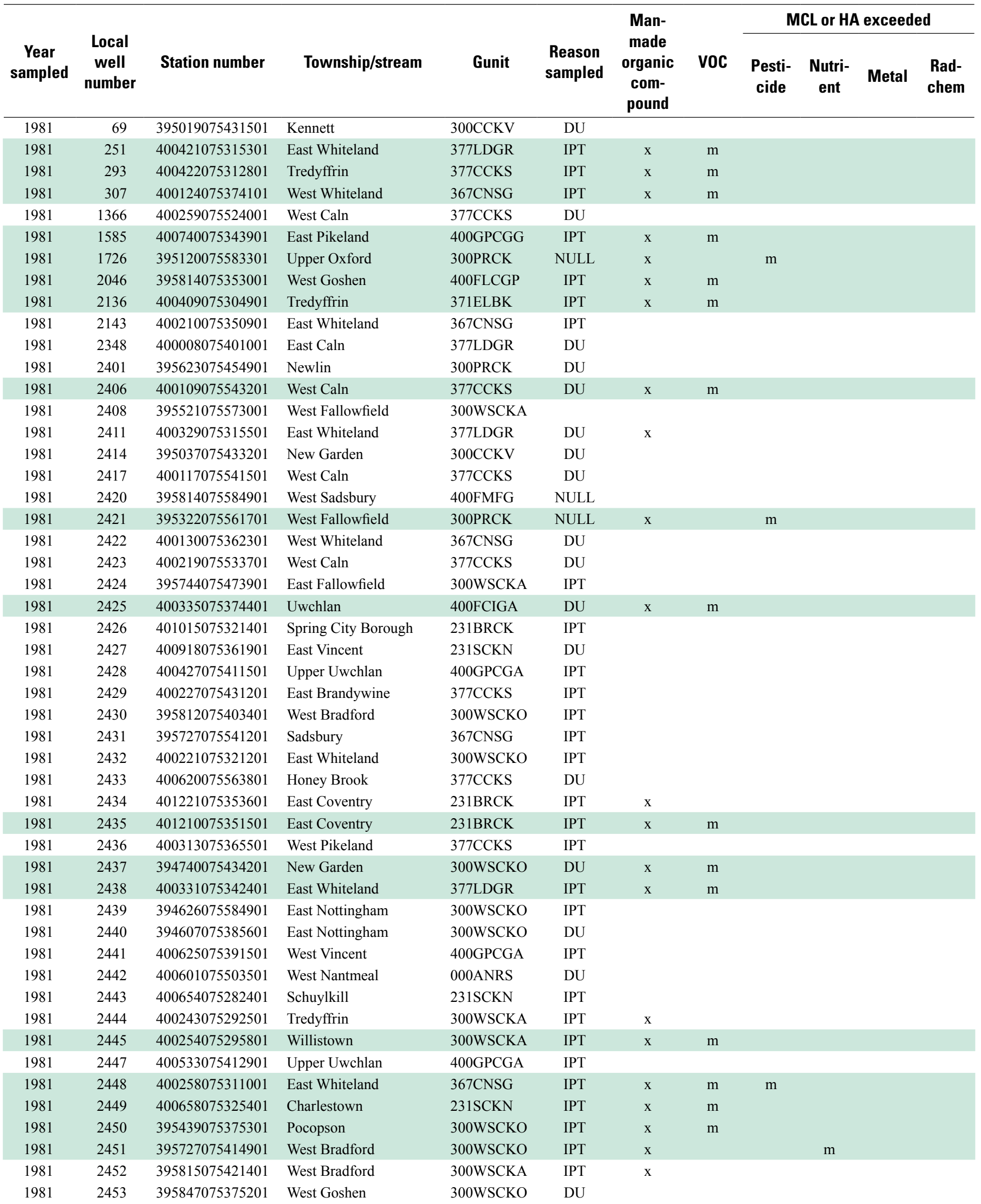


Appendix 1. List of wells and streams sampled by year and summary of water-quality-sampling results for the Chester County groundwater-quality monitoring program, 1980-2008.-Continued

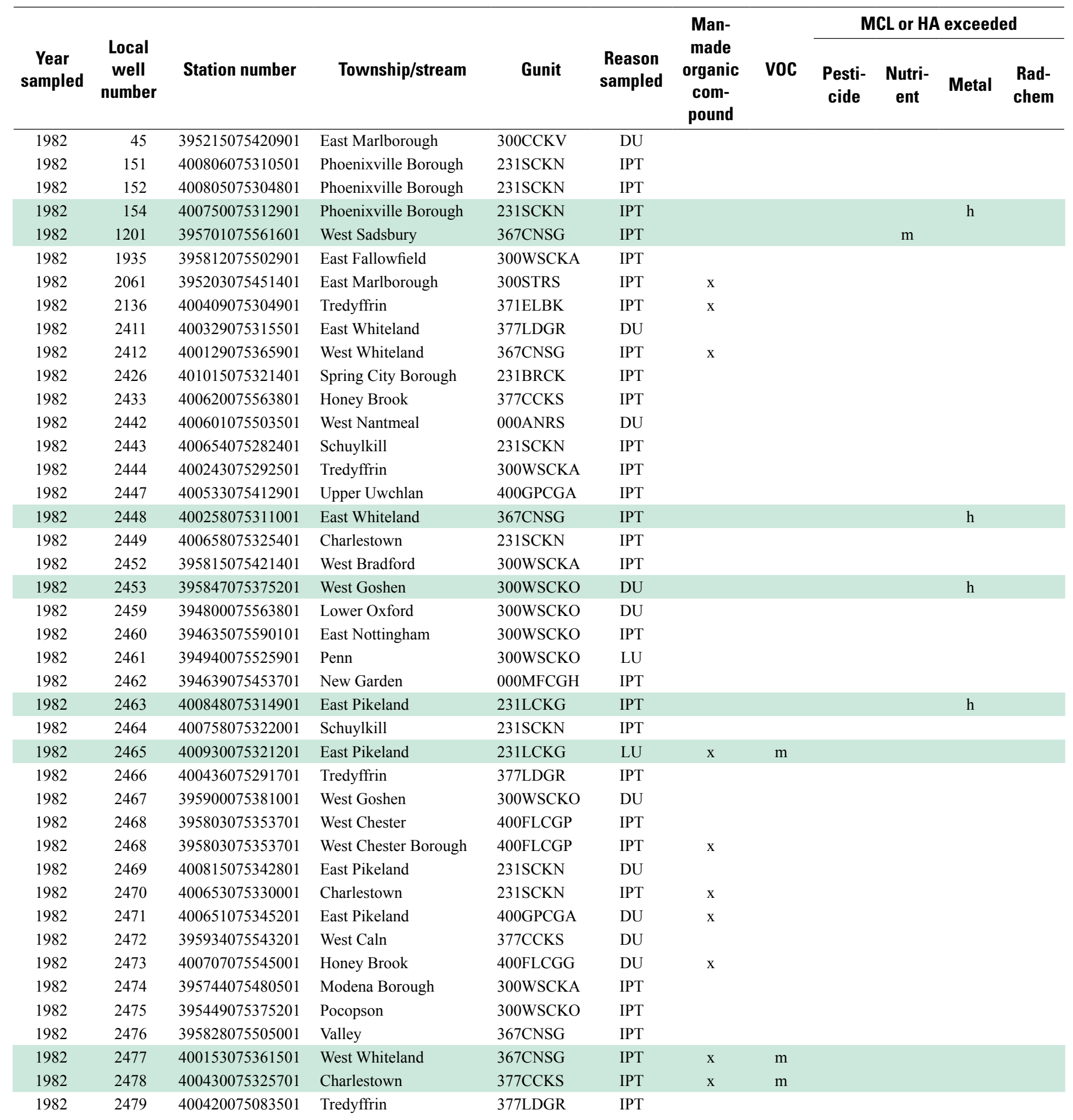


Appendix 1. List of wells and streams sampled by year and summary of water-quality-sampling results for the Chester County groundwater-quality monitoring program, 1980-2008.-Continued

\begin{tabular}{|c|c|c|c|c|c|c|c|c|c|c|c|}
\hline \multirow[b]{2}{*}{$\begin{array}{c}\text { Year } \\
\text { sampled }\end{array}$} & \multirow{2}{*}{$\begin{array}{c}\text { Local } \\
\text { well } \\
\text { number }\end{array}$} & \multirow[b]{2}{*}{ Station number } & \multirow[b]{2}{*}{ Township } & \multirow[b]{2}{*}{ Gunit } & \multirow[b]{2}{*}{$\begin{array}{l}\text { Reason } \\
\text { sampled }\end{array}$} & \multirow{2}{*}{$\begin{array}{c}\text { Man- } \\
\text { made } \\
\text { organic } \\
\text { com- } \\
\text { pound }\end{array}$} & \multirow[b]{2}{*}{ VOC } & \multicolumn{4}{|c|}{ MCL or HA exceeded } \\
\hline & & & & & & & & $\begin{array}{l}\text { Pesti- } \\
\text { cide }\end{array}$ & $\begin{array}{c}\text { Nutri- } \\
\text { ent }\end{array}$ & Metal & $\begin{array}{l}\text { Rad- } \\
\text { chem }\end{array}$ \\
\hline 1983 & 31 & 395030075425801 & Kennett Square & 300CCKV & IPT & $\mathrm{x}$ & $\mathrm{m}$ & & & & \\
\hline 1983 & 155 & 400733075320401 & Phoenixville Borough & 231SCKN & IPT & & & & & & \\
\hline 1983 & 206 & 400555075413901 & Upper Uwchlan & 400GPCGA & LU & $\mathrm{x}$ & & & & & \\
\hline 1983 & 1315 & 400205075372301 & West Whiteland & 377LDGR & IPT & & & & & & \\
\hline 1983 & 1600 & 400449075392501 & West Pikeland & 400GPCGA & LU & & & & & & \\
\hline 1983 & 1613 & 400536075381501 & West Pikeland & 400GPCGA & $\mathrm{LU}$ & & & & & & \\
\hline 1983 & 1969 & 400248075310201 & East Whiteland & $367 \mathrm{CNSG}$ & IPT & $\mathrm{x}$ & & & & & \\
\hline 1983 & 2197 & 400512075291001 & Schuylkill & $377 \mathrm{CCKS}$ & IPT & & & & & & \\
\hline 1983 & 2198 & 400326075290101 & Tredyffrin & 371ELBK & IPT & & & & & & \\
\hline 1983 & 2339 & 395808075365501 & West Chester Borough & 400FLCGH & LU & & & & & & \\
\hline 1983 & 2411 & 400329075315501 & East Whiteland & 377LDGR & DU & & & & & & \\
\hline 1983 & 2419 & 400712075550001 & Honey Brook & 377HLLM & DU & $\mathrm{x}$ & $\mathrm{m}$ & & & & \\
\hline 1983 & 2451 & 395727075414901 & West Bradford & 300WSCKO & IPT & & & & & & \\
\hline 1983 & 2461 & 394940075525901 & Penn & 300WSCKO & $\mathrm{LU}$ & $\mathrm{x}$ & & & & & \\
\hline 1983 & 2469 & 400815075342801 & East Pikeland & $231 \mathrm{SCKN}$ & DU & $\mathrm{x}$ & & & & & \\
\hline 1983 & 2473 & 400707075545001 & Honey Brook & 400FLCGG & DU & $\mathrm{x}$ & & & & & \\
\hline 1983 & 2478 & 400430075325701 & Charlestown & $377 \mathrm{CCKS}$ & IPT & $\mathrm{x}$ & $\mathrm{m}$ & & & & \\
\hline 1983 & 2486 & 400624075331701 & Charlestown & 400GPCGA & IPT & & & & & & \\
\hline 1983 & 2499 & 395739075351301 & West Goshen & 400FLCGP & IPT & & & & & & \\
\hline 1983 & 2500 & 400617075562301 & Honey Brook & 400FLCGG & DU & & & & & & \\
\hline 1983 & 2501 & 400632075562401 & Honey Brook & 377CCKS & DU & & & & & & \\
\hline 1983 & 2502 & 395705075334701 & West Goshen & 400FLCGH & $\mathrm{LU}$ & & & & & & \\
\hline 1983 & 2503 & 395447075410701 & Pocopson & 400FLCGH & $\mathrm{LU}$ & $\mathrm{x}$ & & & & & \\
\hline 1983 & 2504 & 395826075504001 & Valley & $367 \mathrm{CNSG}$ & IPT & & & & & & \\
\hline 1983 & 2505 & 395707075441401 & West Bradford & 300PRCK & IPT & $\mathrm{x}$ & $\mathrm{m}$ & & & & \\
\hline 1983 & 2506 & 395632075453901 & Newlin & 300PRCK & DU & & & & & & \\
\hline 1983 & 2507 & 395359075581101 & West Fallowfield & 300PRCK & IPT & $\mathrm{x}$ & & & & & \\
\hline
\end{tabular}


Appendix 1. List of wells and streams sampled by year and summary of water-quality-sampling results for the Chester County groundwater-quality monitoring program, 1980-2008.-Continued

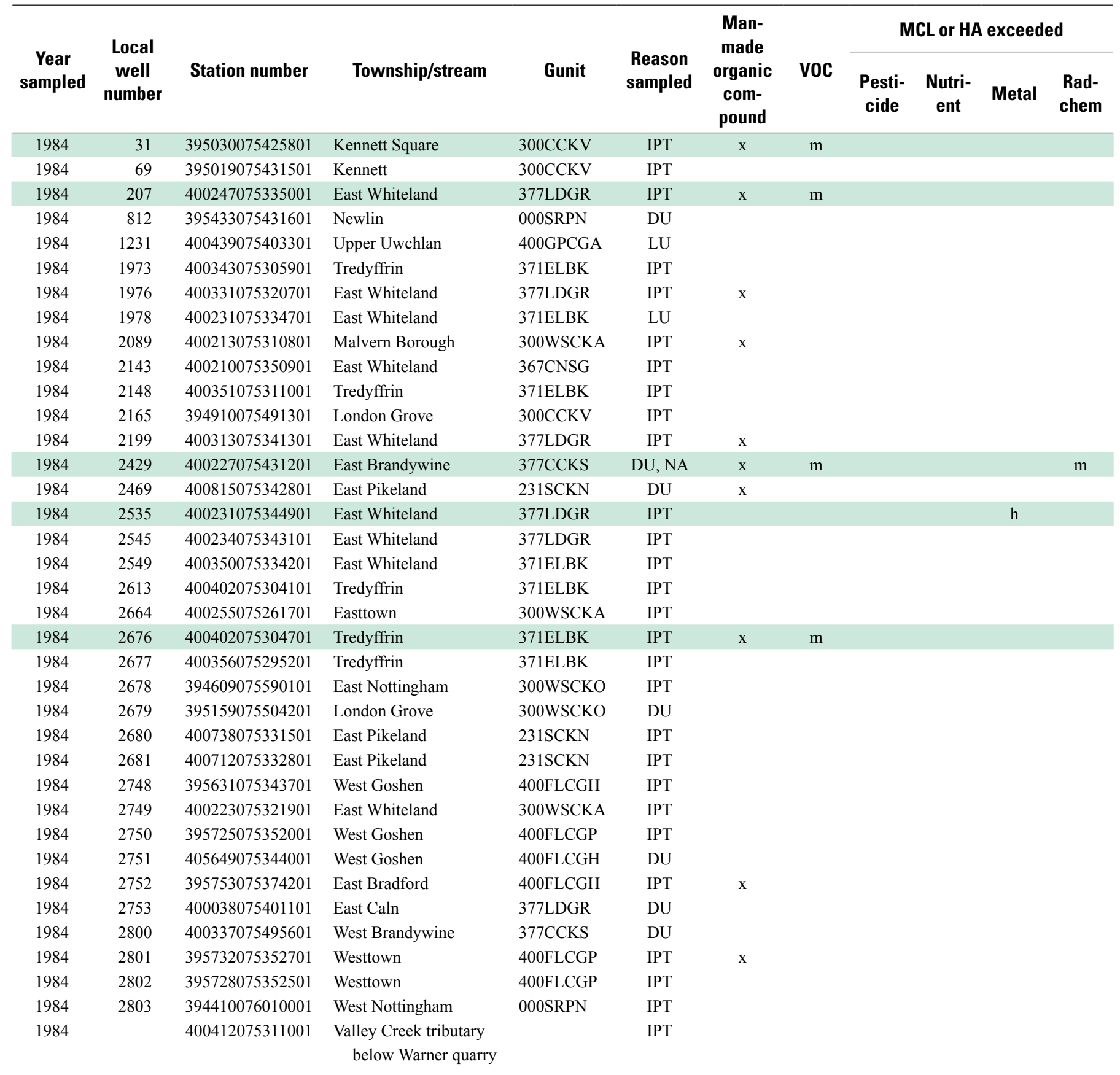


Appendix 1. List of wells and streams sampled by year and summary of water-quality-sampling results for the Chester County groundwater-quality monitoring program, 1980-2008.-Continued

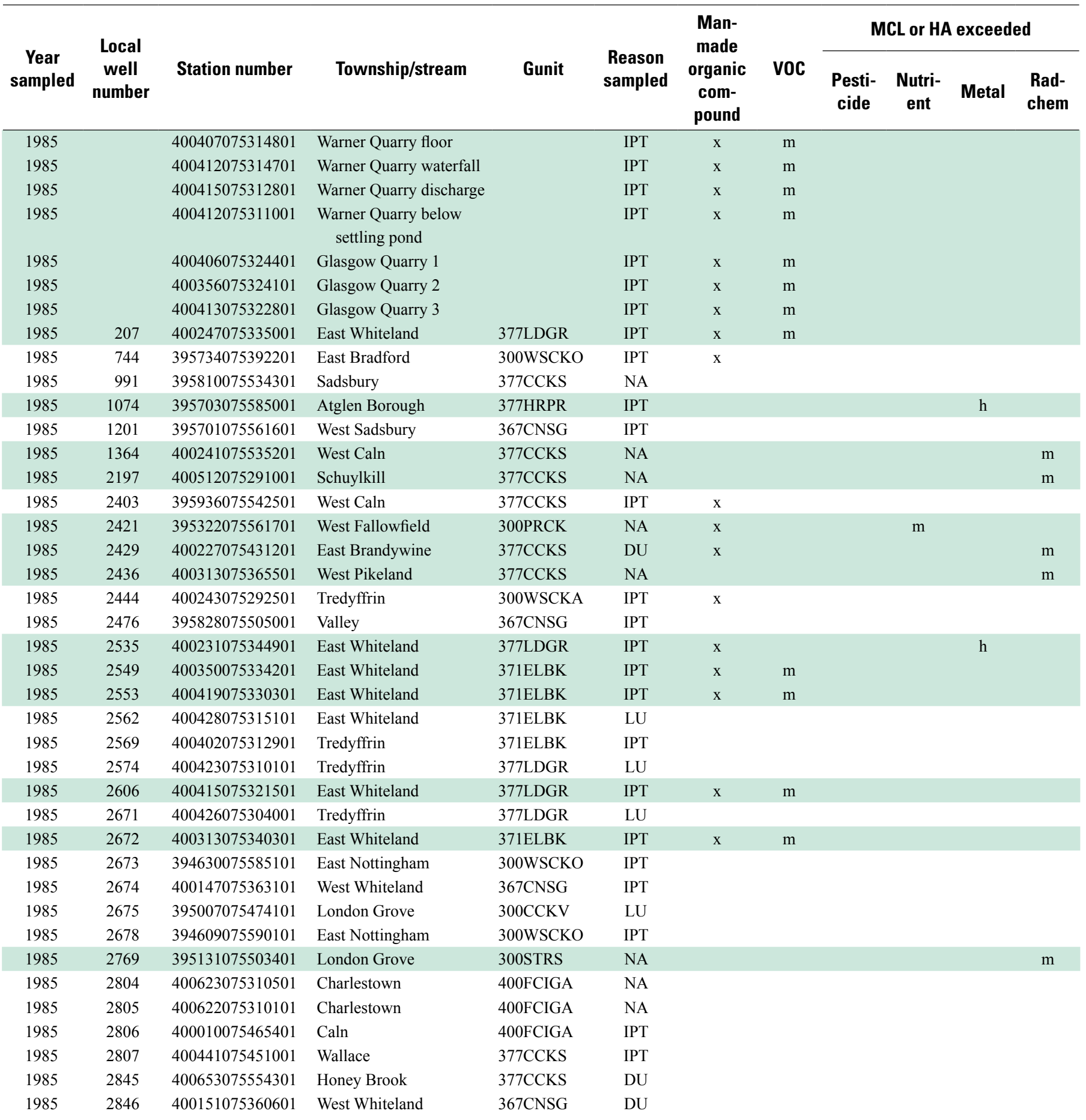


Appendix 1. List of wells and streams sampled by year and summary of water-quality-sampling results for the Chester County groundwater-quality monitoring program, 1980-2008.-Continued

\begin{tabular}{|c|c|c|c|c|c|c|c|c|c|c|c|}
\hline $\begin{array}{c}\text { Year } \\
\text { sampled }\end{array}$ & $\begin{array}{c}\text { Local } \\
\text { well } \\
\text { number }\end{array}$ & Station number & Township/stream & Gunit & $\begin{array}{l}\text { Reason } \\
\text { sampled }\end{array}$ & $\begin{array}{c}\text { Man- } \\
\text { made } \\
\text { organic } \\
\text { com- } \\
\text { pound }\end{array}$ & VOC & \multicolumn{4}{|c|}{ MCL or HA exceeded } \\
\hline 1986 & 71 & 395017075433801 & New Garden & 300CCKV & LU & & & & $\mathrm{m}$ & & \\
\hline 1986 & 75 & 394735075580901 & Oxford Borough & 300WSCKO & LU & & & & & & \\
\hline 1986 & 83 & 395346075421001 & East Marlborough & 300WSCKO & LU & & & & & & \\
\hline 1986 & 84 & 400738075335501 & East Pikeland & 231SCKN & IPT & $\mathrm{x}$ & & & & & \\
\hline 1986 & 85 & 395706075453001 & West Bradford & 300WSCKA & DU & & & & & & \\
\hline 1986 & 86 & 400227075430801 & East Brandywine & 377CCKS & DU & & & & & & \\
\hline 1986 & 88 & 400234075342601 & East Whiteland & 377LDGR & IPT & & & & & & \\
\hline 1986 & 1000 & 395433075543601 & Highland & 300PRCK & NA & & & & & & \\
\hline 1986 & 1074 & 395703075585001 & Atglen Borough & 377HRPR & IPT & & & & & $\mathrm{h}$ & \\
\hline 1986 & 1299 & 395420075393701 & Pocopson 3 & 300WSCKO & LU & & & & & & \\
\hline 1986 & 1361 & 400109075545501 & West Caln & 377HRPR & NA & & & & & & \\
\hline 1986 & 1364 & 400241075535201 & West Caln & 377CCKS & NA & & & & & & $\mathrm{m}$ \\
\hline 1986 & 1370 & 400242075502901 & West Caln & 400BMFGA & NA & & & & & & \\
\hline 1986 & 1435 & 400706075431501 & East Nantmeal & 400FLCGG & NA & & & & & & \\
\hline 1986 & 1528 & 401259075405501 & North Coventry & 231HMCK & NA & & & & & & \\
\hline 1986 & 1547 & 401200075354601 & East Coventry & 231BRCK & NA & & & & & & \\
\hline 1986 & 1565 & 400935075360401 & East Vincent & 231LCKG & NA & & & & & & \\
\hline 1986 & 1593 & 400800075343201 & East Pikeland & $231 \mathrm{SCKN}$ & NA & $\mathrm{x}$ & $\mathrm{m}$ & & & & \\
\hline 1986 & 2197 & 400512075291001 & Schuylkill & 377CCKS & IPT & & & & & & $\mathrm{m}$ \\
\hline 1986 & 2271 & 400425075490801 & West Brandywine & 000ANRS & NA & & & & & & \\
\hline 1986 & 2293 & 395549075341801 & Westtown & 400FLCGH & NA & & & & & & \\
\hline 1986 & 2308 & 400049075324901 & East Goshen & 300WSCKO & NA & & & & & & \\
\hline 1986 & 2403 & 395936075542501 & West Caln & 377CCKS & DU, NA & $\mathrm{x}$ & $\mathrm{m}$ & & & & $\mathrm{m}$ \\
\hline 1986 & 2415 & 395731075485201 & South Coatesville & 300PRCK & DU & $\mathrm{x}$ & & & & & \\
\hline 1986 & 2429 & 400227075431201 & East Brandywine & 377CCKS & NA & & & & & & $\mathrm{m}$ \\
\hline 1986 & 2436 & 400313075365501 & West Pikeland & 377CCKS & NA & & & & & & $\mathrm{m}$ \\
\hline 1986 & 2482 & 400731075340201 & East Pikeland & 400GPCGA & IPT & $\mathrm{x}$ & & & & & \\
\hline 1986 & 2505 & 395707075441401 & West Bradford & 300PRCK & IPT & $\mathrm{x}$ & $\mathrm{m}$ & & & & \\
\hline 1986 & 2541 & 400254075335801 & East Whiteland & 377CCKS & IPT & & & & & & \\
\hline 1986 & 2555 & 400422075331601 & East Whiteland & 377CCKS & IPT & & & & & & \\
\hline 1986 & 2605 & 400403075321601 & East Whiteland & 367CNSG & IPT & $\mathrm{x}$ & $\mathrm{m}$ & & & & \\
\hline 1986 & 2714 & 400102075423601 & Caln B-1 & 377LDGR & IPT & & & & & & \\
\hline 1986 & 2745 & 400158075352801 & West Whiteland & $367 \mathrm{CNSG}$ & IPT & & & & & & \\
\hline 1986 & 2746 & 400200075365001 & West Whiteland & 377LDGR & NA & & & & & & \\
\hline 1986 & 2769 & 395131075503401 & London Grove & 300STRS & NA & & & & & & \\
\hline 1986 & 3048 & 395820075530501 & Sadsbury & 400FMFG & NA & & & & & & \\
\hline 1986 & 3073 & 395323075350001 & Birmingham & 000MFCGH & NA & & & & & & \\
\hline 1986 & 3219 & 400243075534301 & West Caln & 377CCKS & NA & & & & & & $\mathrm{m}$ \\
\hline
\end{tabular}


Appendix 1. List of wells and streams sampled by year and summary of water-quality-sampling results for the Chester County groundwater-quality monitoring program, 1980-2008.-Continued

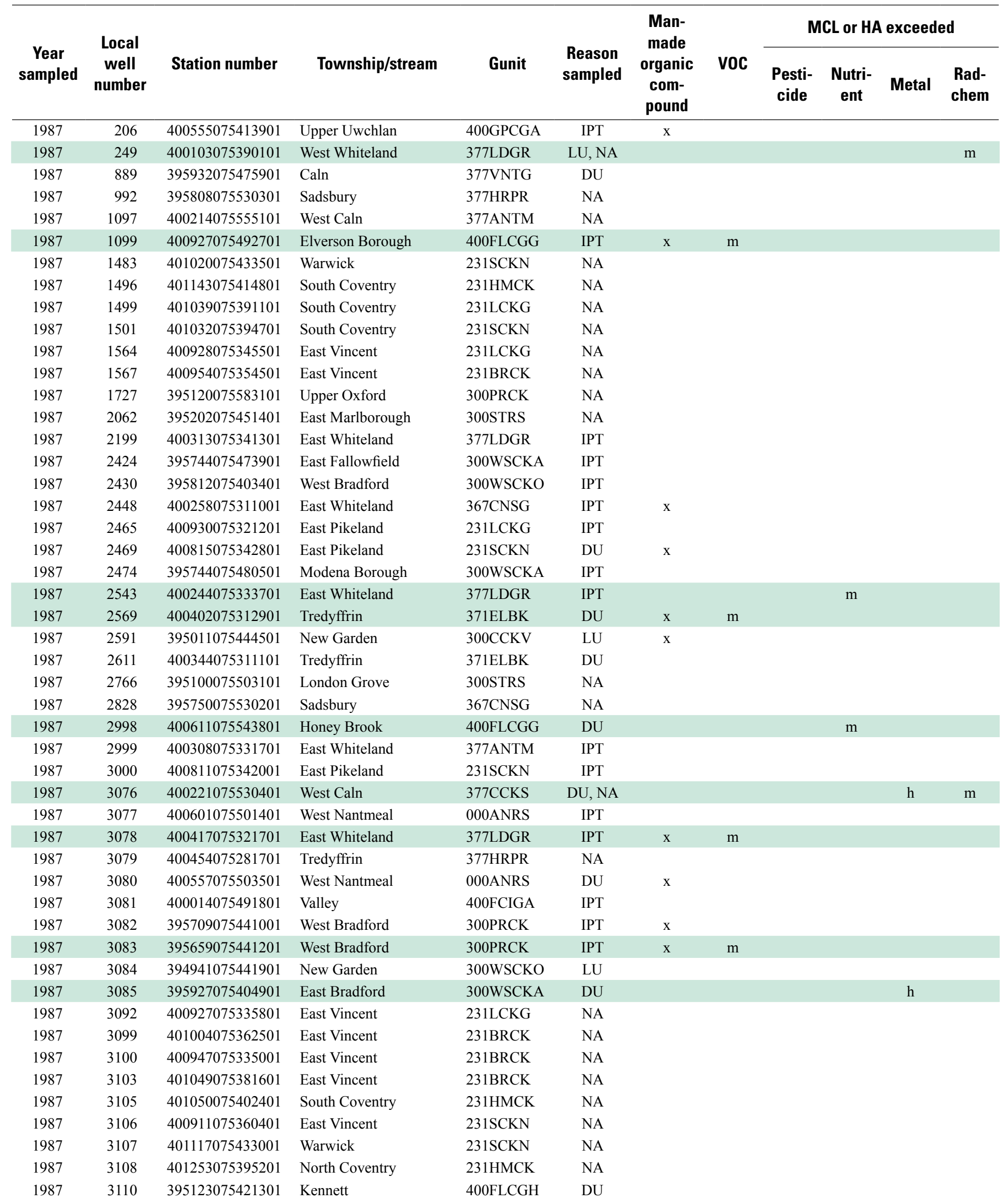


62 Groundwater-Quality Monitoring Program in Chester County, Pennsylvania, 1980-2008

Appendix 1. List of wells and streams sampled by year and summary of water-quality-sampling results for the Chester County groundwater-quality monitoring program, 1980-2008.-Continued

\begin{tabular}{|c|c|c|c|c|c|c|c|c|c|c|c|}
\hline \multirow[b]{2}{*}{$\begin{array}{c}\text { Year } \\
\text { sampled }\end{array}$} & \multirow{2}{*}{$\begin{array}{c}\text { Local } \\
\text { well } \\
\text { number }\end{array}$} & \multirow[b]{2}{*}{ Station number } & \multirow[b]{2}{*}{ Township/stream } & \multirow[b]{2}{*}{ Gunit } & \multirow[b]{2}{*}{$\begin{array}{l}\text { Reason } \\
\text { sampled }\end{array}$} & \multirow{2}{*}{$\begin{array}{c}\text { Man- } \\
\text { made } \\
\text { organic } \\
\text { com- } \\
\text { pound }\end{array}$} & \multirow[b]{2}{*}{ VOC } & \multicolumn{4}{|c|}{ MCL or HA exceeded } \\
\hline & & & & & & & & $\begin{array}{l}\text { Pesti- } \\
\text { cide }\end{array}$ & $\begin{array}{l}\text { Nutri- } \\
\text { ent }\end{array}$ & Metal & $\begin{array}{l}\text { Rad- } \\
\text { chem }\end{array}$ \\
\hline 1987 & 3115 & 401336075413601 & North Coventry & 231BRCK & NA & & & & & & \\
\hline 1987 & 3116 & 401246075381001 & East Coventry & 231BRCK & NA & & & & & & \\
\hline 1987 & 3120 & 395251075581501 & West Fallowfield & 300PRCK & NA & & & & & & \\
\hline 1987 & 3121 & 401152075383401 & East Coventry & 231HMCK & NA & & & & & & \\
\hline 1987 & 3129 & 395057075400701 & Kennett & 300STRS & NA & & & & & & \\
\hline 1987 & 3130 & 394832075435501 & New Garden & 300WSCKO & IPT & & & & $\mathrm{m}$ & & \\
\hline 1987 & 3133 & 400217075534301 & West Caln & 377CCKS & DU & $\mathrm{x}$ & $\mathrm{m}$ & & & & \\
\hline
\end{tabular}


Appendix 1. List of wells and streams sampled by year and summary of water-quality-sampling results for the Chester County groundwater-quality monitoring program, 1980-2008.-Continued

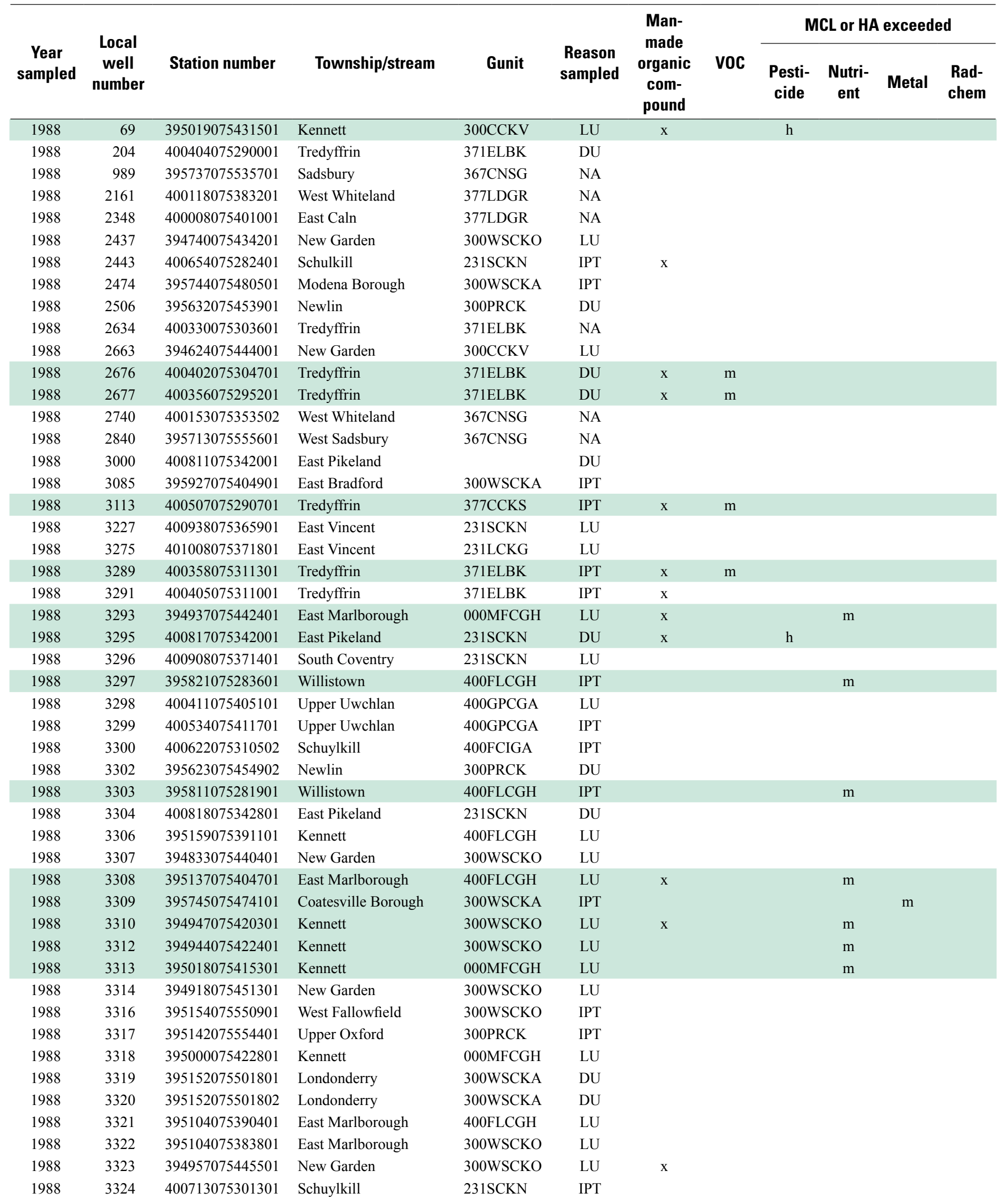


Appendix 1. List of wells and streams sampled by year and summary of water-quality-sampling results for the Chester County groundwater-quality monitoring program, 1980-2008.-Continued

\begin{tabular}{|c|c|c|c|c|c|c|c|c|c|c|c|}
\hline \multirow{2}{*}{$\begin{array}{c}\text { Year } \\
\text { sampled }\end{array}$} & \multirow{2}{*}{$\begin{array}{c}\text { Local } \\
\text { well } \\
\text { number }\end{array}$} & \multirow[b]{2}{*}{ Station number } & \multirow[b]{2}{*}{ Township/stream } & \multirow[b]{2}{*}{ Gunit } & \multirow[b]{2}{*}{$\begin{array}{l}\text { Reason } \\
\text { sampled }\end{array}$} & \multirow{2}{*}{$\begin{array}{c}\text { Man- } \\
\text { made } \\
\text { organic } \\
\text { com- } \\
\text { pound }\end{array}$} & \multirow[b]{2}{*}{ VOC } & \multicolumn{4}{|c|}{ MCL or HA exceeded } \\
\hline & & & & & & & & $\begin{array}{l}\text { Pesti- } \\
\text { cide }\end{array}$ & $\begin{array}{c}\text { Nutri- } \\
\text { ent }\end{array}$ & Metal & $\begin{array}{l}\text { Rad- } \\
\text { chem }\end{array}$ \\
\hline 1989 & 85 & 395706075453001 & West Bradford & 300WSCKA & DU & & & & & & \\
\hline 1989 & 87 & 395705075452701 & West Bradford & 300WSCKA & DU & & & & & & \\
\hline 1989 & 2197 & 400512075291001 & Schuylkill & 377CCKS & IPT & & & & & & \\
\hline 1989 & 2315 & 400239075371501 & West Whiteland & 377CCKS & LU & & & & & & \\
\hline 1989 & 2411 & 400329075315501 & East Whiteland & 377LDGR & DU & $\mathrm{x}$ & & & & & \\
\hline 1989 & 2494 & 400334075313801 & East Whiteland & 377LDGR & DU & & & & & & \\
\hline 1989 & 2586 & 395040075403701 & Kennett & $300 \mathrm{CCKV}$ & DU & $\mathrm{x}$ & & & & & \\
\hline 1989 & 3310 & 394947075420301 & Kennett & 300WSCKO & LU & & & & $\mathrm{m}$ & & \\
\hline 1989 & 3335 & 400332075361801 & Charlestown & 377CCKS & IPT & & & & & & \\
\hline 1989 & 3355 & 400519075291701 & Schuylkill & 377CCKS & LU & & & & & & \\
\hline 1989 & 3356 & 395313075451701 & East Marlborough & 300WSCKO & IPT & $\mathrm{x}$ & & & & & \\
\hline 1989 & 3357 & 400812075341701 & East Pikeland & $231 \mathrm{SCKN}$ & LU & & & & & & \\
\hline 1989 & 3358 & 395902075512201 & Valley & 400FMFG & IPT & & & & & & \\
\hline 1989 & 3359 & 400822075342101 & East Pikeland & $231 \mathrm{SCKN}$ & IPT & & & & & & \\
\hline 1989 & 3360 & 400517075291601 & Schuylkill & $377 \mathrm{CCKS}$ & IPT & & & & & & \\
\hline 1989 & 3361 & 395629075342701 & Westtown & 400MFCGH & LU & & & & & & \\
\hline 1989 & 3362 & 400220075364701 & West Whiteland & 377LDGR & LU & & & & & & \\
\hline 1989 & 3363 & 400156075362901 & West Whiteland & 377LDGR & LU & $\mathrm{x}$ & $\mathrm{m}$ & & & & \\
\hline 1989 & 3471 & 395049075403401 & Kennett & 300STRS & LU & & & & & & \\
\hline 1989 & 3472 & 394757075433301 & New Garden & 300WSCKO & LU & & & & & & \\
\hline 1989 & 3473 & 395053075395801 & Kennett & 300STRS & LU & $\mathrm{x}$ & & & & & \\
\hline 1989 & 3474 & 395008075444101 & New Garden & $300 \mathrm{CCKV}$ & IPT & $\mathrm{x}$ & & & & & \\
\hline 1989 & 3475 & 400816075341801 & East Pikeland & 231SCKN & LU & $\mathrm{x}$ & & $\mathrm{h}$ & & & \\
\hline 1989 & 3478 & 394927075430401 & Kennett & 300WSCKO & LU & & & & & & \\
\hline 1989 & 3539 & 395005075422801 & Kennett & 300WSCKO & IPT & $\mathrm{x}$ & & & & & \\
\hline 1989 & 3540 & 395650075352601 & West Goshen & 400FLCGP & LU & $\mathrm{x}$ & $\mathrm{m}$ & & $\mathrm{m}$ & & \\
\hline 1989 & 3551 & 400228075354402 & West Whiteland & 377CCKS & DU & & & & & & \\
\hline 1989 & 3621 & 395148075502402 & London Grove & 300WSCKO & DU & $\mathrm{x}$ & & & & & \\
\hline 1989 & 3622 & 395200075502601 & London Grove & 300WSCKO & DU & & & & & & \\
\hline 1989 & 3623 & 395148075502401 & London Grove & 300WSCKO & DU & $\mathrm{x}$ & & & & & \\
\hline
\end{tabular}


Appendix 1. List of wells and streams sampled by year and summary of water-quality-sampling results for the Chester County groundwater-quality monitoring program, 1980-2008.-Continued

\begin{tabular}{|c|c|c|c|c|c|c|c|c|c|c|c|}
\hline $\begin{array}{c}\text { Year } \\
\text { sampled }\end{array}$ & $\begin{array}{c}\text { Local } \\
\text { well } \\
\text { number }\end{array}$ & Station number & Township/stream & Gunit & $\begin{array}{l}\text { Reason } \\
\text { sampled }\end{array}$ & $\begin{array}{c}\text { Man- } \\
\text { made } \\
\text { organic } \\
\text { com- } \\
\text { pound }\end{array}$ & VOC & \multicolumn{4}{|c|}{ MCL or HA exceeded } \\
\hline 1990 & 75 & 394735075580901 & Oxford Borough & 300WSCKO & LU & $\mathrm{x}$ & & & & & \\
\hline 1990 & 895 & 395438075484101 & West Marlborough & $300 \mathrm{CCKV}$ & NA & & & & & & \\
\hline 1990 & 2746 & 400200075365001 & West Whiteland & 377LDGR & IPT & & & & & & \\
\hline 1990 & 2752 & 395753075374201 & East Bradford & 400FLCGH & IPT & & & & & & \\
\hline 1990 & 2777 & 395045075474201 & London Grove & $300 \mathrm{CCKV}$ & NA & & & & & & \\
\hline 1990 & 3310 & 394947075420301 & Kennett & 300WSCKO & LU & & & & & & \\
\hline 1990 & 3316 & 395154075550901 & West Fallowfield & 300WSCKO & IPT & & & & & $\mathrm{h}$ & \\
\hline 1990 & 3627 & 395154075505701 & London Grove & 300WSCKO & DU & $\mathrm{x}$ & & & $\mathrm{m}$ & $\mathrm{h}$ & \\
\hline 1990 & 3640 & 401316075421001 & North Coventry & 231BRCK & NA & & & & & & \\
\hline 1990 & 3655 & 401302075431501 & North Coventry & 231BRCK & NA & & & & & & \\
\hline 1990 & 3657 & 401236075433101 & North Coventry & 231HMCK & NA & & & & & & \\
\hline 1990 & 3673 & 401342075431801 & North Coventry & 231HMCK & NA & & & & & & \\
\hline 1990 & 3758 & 401058075383501 & South Coventry & 231HMCK & NA & & & & & & \\
\hline 1990 & 3837 & 401408075400101 & North Coventry & 231BRCK & NA & & & & & & \\
\hline 1990 & 3838 & 401411075421301 & North Coventry & 231BRCK & NA & & & & & & \\
\hline 1990 & 3932 & 395156075510201 & Londonderry & 300WSCKO & IPT & $\mathrm{x}$ & & $\mathrm{m}$ & & & \\
\hline 1990 & 4004 & 395312075431301 & East Marlborough & 300WSCKO & IPT & & & & & & \\
\hline 1990 & 4005 & 394832075435701 & New Garden & 300WSCKO & LU & & & & & & \\
\hline 1990 & 4024 & 395200075405601 & East Marlborough & 400FLCGH & $\mathrm{LU}$ & & & & & & \\
\hline 1990 & 4025 & 400516075510301 & Honey Brook & 000ANRS & NA & & & & & & \\
\hline 1990 & 4026 & 394617075444901 & New Garden & $300 \mathrm{CCKV}$ & NA & & & & & & \\
\hline 1990 & SP41 & 400501075290901 & Tredyffrin & 377CCKS & IPT & & & & & & \\
\hline 1990 & SP42 & 400157075364001 & West Whiteland & 377LDGR & IPT & $\mathrm{x}$ & $\mathrm{m}$ & & & & \\
\hline
\end{tabular}


Appendix 1. List of wells and streams sampled by year and summary of water-quality-sampling results for the Chester County groundwater-quality monitoring program, 1980-2008.-Continued

\begin{tabular}{|c|c|c|c|c|c|c|c|c|c|c|c|}
\hline $\begin{array}{c}\text { Year } \\
\text { sampled }\end{array}$ & $\begin{array}{c}\text { Local } \\
\text { well } \\
\text { number }\end{array}$ & Station number & Township/Stream & Gunit & $\begin{array}{l}\text { Reason } \\
\text { sampled }\end{array}$ & $\begin{array}{c}\text { Man- } \\
\text { made } \\
\text { organic } \\
\text { com- } \\
\text { pound }\end{array}$ & VOC & \multicolumn{4}{|c|}{ MCL or HA exceeded } \\
\hline 1991 & 307 & 400124075374101 & West Whiteland & $367 \mathrm{CNSG}$ & IPT & & & & & & \\
\hline 1991 & 509 & 395157075510601 & Londonderry & 300WSCKO & IPT & & & & $\mathrm{m}$ & $\mathrm{h}$ & \\
\hline 1991 & 1703 & 394445075580201 & East Nottingham & 300WSCKO & NA & & & & & & \\
\hline 1991 & 1709 & 394859075591701 & Lower Oxford & 300PRCK & NA & & & & & & \\
\hline 1991 & 1737 & 394752075545901 & Lower Oxford & 300WSCKO & NA & & & & $\mathrm{m}$ & & \\
\hline 1991 & 1761 & 394407075562501 & Elk & 000SRPN & NA & & & & & & \\
\hline 1991 & 1765 & 394620075541201 & New London & 300WSCKO & NA & & & & & & \\
\hline 1991 & 2742 & 400227075361301 & West Whiteland & 377LDGR & LU & & & & $\mathrm{m}$ & & \\
\hline 1991 & 2755 & 395137075501001 & W Marlborough & 400FLCGH & IPT & $\mathrm{x}$ & & & $\mathrm{m}$ & & \\
\hline 1991 & 3272 & 401107075355901 & South Coventry & 231BRCK & IPT & & & & & & \\
\hline 1991 & 3310 & 394947075420301 & Kennett & 300WSCKO & LU & & & & $\mathrm{m}$ & & \\
\hline 1991 & 3335 & 400332075361801 & Charlestown & 377CCKS & NA & & & & & & \\
\hline 1991 & 3561 & 395058075383701 & Kennett & 300WSCKO & LU & & & & & & \\
\hline 1991 & 3841 & 401406075392201 & North Coventry & 231BRCK & LU & & & & & & \\
\hline 1991 & 3926 & 400233075355601 & West Whiteland & 377LDGR & LU & $\mathrm{x}$ & & & $\mathrm{m}$ & & \\
\hline 1991 & 4026 & 394617075444901 & New Garden & $300 \mathrm{CCKV}$ & LU & & & & & & \\
\hline 1991 & 4118 & 394638075563601 & East Nottingham & 300WSCK & NA & & & & & & \\
\hline 1991 & 4119 & 394854076010701 & Lower Oxford & 300PRCK & NA & & & & $\mathrm{m}$ & & \\
\hline 1991 & 4127 & 395319075552101 & West Fallowfield & 300PRCK & IPT & $\mathrm{x}$ & & & & & \\
\hline 1991 & 4128 & 395333075551902 & West Fallowfield & 300PRCK & IPT & $\mathrm{x}$ & & & $\mathrm{m}$ & & \\
\hline 1991 & 4129 & 400026075400901 & East Caln & $367 \mathrm{CNSG}$ & IPT & $\mathrm{x}$ & & & & & \\
\hline 1991 & SP43 & 395200075501801 & London Grove & 300STRS & IPT & $\mathrm{x}$ & & & & & \\
\hline
\end{tabular}


Appendix 1. List of wells and streams sampled by year and summary of water-quality-sampling results for the Chester County groundwater-quality monitoring program, 1980-2008.-Continued

\begin{tabular}{|c|c|c|c|c|c|c|c|c|c|c|c|}
\hline \multirow[b]{2}{*}{$\begin{array}{c}\text { Year } \\
\text { sampled }\end{array}$} & \multirow[b]{2}{*}{$\begin{array}{c}\text { Local } \\
\text { well } \\
\text { number }\end{array}$} & \multirow[b]{2}{*}{ Station number } & \multirow[b]{2}{*}{ Township/stream } & \multirow[b]{2}{*}{ Gunit } & \multirow[b]{2}{*}{$\begin{array}{l}\text { Reason } \\
\text { sampled }\end{array}$} & \multirow{2}{*}{$\begin{array}{c}\text { Man- } \\
\text { made } \\
\text { organic } \\
\text { com- } \\
\text { pound }\end{array}$} & \multirow[b]{2}{*}{ VOC } & \multicolumn{4}{|c|}{ MCL or HA exceeded } \\
\hline & & & & & & & & $\begin{array}{l}\text { Pesti- } \\
\text { cide }\end{array}$ & $\begin{array}{c}\text { Nutri- } \\
\text { ent }\end{array}$ & Metal & $\begin{array}{l}\text { Rad- } \\
\text { chem }\end{array}$ \\
\hline 1992 & 1315 & 400205075372301 & West Whiteland & 377LDGR & IPT & $\mathrm{x}$ & & & & & \\
\hline 1992 & 1316 & 400205075372101 & West Whiteland & 377LDGR & IPT & & & & & & \\
\hline 1992 & 1617 & 400338075352701 & Charlestown & 377CCKS & NA & & & & & & \\
\hline 1992 & 1720 & 394803075563801 & Lower Oxford & 300WSCKO & LU & $\mathrm{x}$ & & & $\mathrm{m}$ & & \\
\hline 1992 & 2279 & 395916075381901 & West Goshen & 300PRCK & $\mathrm{LU}$ & & & & & & \\
\hline 1992 & 2969 & 395949075390801 & East Bradford & 300WSCKA & LU & & & & & & \\
\hline 1992 & 3335 & 400332075361801 & Charlestown & 377CCKS & NA & & & & & & \\
\hline 1992 & 4148 & 395909075384701 & East Bradford & 300PRCK & $\mathrm{LU}$ & & & & & & \\
\hline 1992 & 4270 & 395332075552101 & West Fallowfield & 300PRCK & IPT & & & & & $\mathrm{h}$ & \\
\hline 1992 & 4271 & 395423075431101 & Newlin & $\begin{array}{l}\text { 000SRPN; } \\
\text { 231DIBS }\end{array}$ & DU & $\mathrm{x}$ & & & & & \\
\hline 1992 & 4272 & 394523076044301 & West Nottingham & 300PRCK & NA & & & & & & \\
\hline 1992 & 4273 & 394438076035601 & West Nottingham & 300PRCK & NA & & & & & & \\
\hline 1992 & 4274 & 394439076035601 & West Nottingham & 300PRCK & NA & & & & & & \\
\hline 1992 & 4275 & 394656075551801 & East Nottingham & 300WSCKO & DU & & & & & & \\
\hline 1992 & 4276 & 401220075393701 & North Coventry & 231BRCK & IPT & $\mathrm{x}$ & & & & & \\
\hline 1992 & 4277 & 401254075394901 & North Coventry & 231HMCK & IPT & & & & & & \\
\hline 1992 & 4278 & 401244075390601 & North Coventry & 231HMCK & IPT & & & & & & \\
\hline 1992 & 4291 & 395137075492801 & London Grove & 000PGMT & NA & & & & & & \\
\hline 1992 & 4292 & 400106075381501 & West Whiteland & $\begin{array}{l}\text { 367CNSG; } \\
\text { 371ELBK }\end{array}$ & IPT & & & & & & \\
\hline 1992 & 4293 & 400113075382701 & West Whiteland & 377LDGR & IPT & $\mathrm{x}$ & & & & & \\
\hline 1992 & 4294 & 394857075504201 & London Grove & 300WSCKO & $\mathrm{LU}$ & & & & & & \\
\hline 1992 & 4295 & 394913075502301 & London Grove & 300WSCKO & LU & $\mathrm{x}$ & & $\mathrm{m}$ & & & \\
\hline 1992 & 4296 & 394647075484901 & Franklin & 300WSCKO & LU & $\mathrm{x}$ & & & & & \\
\hline 1992 & 4297 & 394752075582201 & Lower Oxford & 300WSCKO & $\mathrm{LU}$ & $\mathrm{x}$ & & & $\mathrm{m}$ & & \\
\hline 1992 & 4298 & 400458075382701 & West Pikeland & 400GPCGA & IPT & $\mathrm{x}$ & & & & & \\
\hline 1992 & 4299 & 394659075450401 & New Garden & $\begin{array}{l}\text { 000MFCGH; } \\
\text { 300WSCKO }\end{array}$ & IPT & $\mathrm{x}$ & & & & & \\
\hline 1992 & 4341 & 394726075505501 & New London & 300WSCKO & LU & $\mathrm{x}$ & & & $\mathrm{m}$ & & \\
\hline 1992 & 4342 & 395038075513601 & Penn & 300WSCKO & $\mathrm{LU}$ & $\mathrm{x}$ & & & & & \\
\hline 1992 & 4343 & 395330075434401 & East Marlborough & 300WSCKO & NA & & & & & & \\
\hline 1993 & 4344 & 395231075420101 & East Marlborough & $300 \mathrm{CCKV}$ & NA & & & & & & \\
\hline 1992 & SP44 & 395014075530201 & Penn & 300WSCKO & NA & & & & & & \\
\hline
\end{tabular}


Appendix 1. List of wells and streams sampled by year and summary of water-quality-sampling results for the Chester County groundwater-quality monitoring program, 1980-2008.-Continued

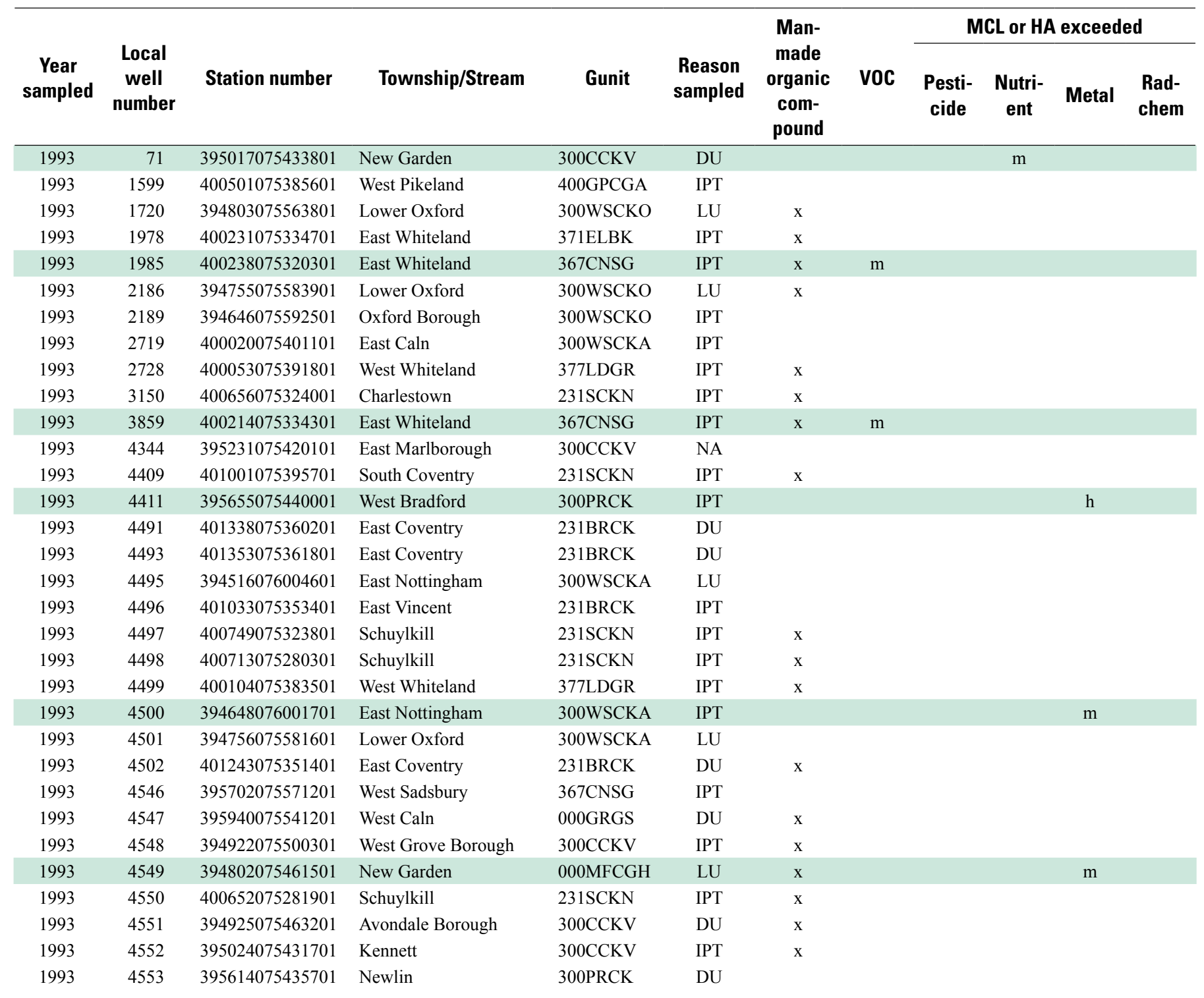


Appendix 1. List of wells and streams sampled by year and summary of water-quality-sampling results for the Chester County groundwater-quality monitoring program, 1980-2008.-Continued

\begin{tabular}{|c|c|c|c|c|c|c|c|c|c|c|c|}
\hline $\begin{array}{c}\text { Year } \\
\text { sampled }\end{array}$ & $\begin{array}{c}\text { Local } \\
\text { well } \\
\text { number }\end{array}$ & Station number & Township/Stream & Gunit & $\begin{array}{l}\text { Reason } \\
\text { sampled }\end{array}$ & $\begin{array}{c}\text { Man- } \\
\text { made } \\
\text { organic } \\
\text { com- } \\
\text { pound }\end{array}$ & VOC & \multicolumn{4}{|c|}{ MCL or HA exceeded } \\
\hline 1994 & 2317 & 401006075431401 & Warwick & 400FLCGG & LU & & & & & & \\
\hline 1994 & 2402 & 400313075315001 & East Whiteland & 377LDGR & DU & $\mathrm{x}$ & & & & & \\
\hline 1994 & 3384 & 395201075421601 & East Marlborough & 400FLCGH & LU & $\mathrm{x}$ & & & & & \\
\hline 1994 & 3430 & 395123075400201 & Kennett & 400FLCGH & LU & $\mathrm{x}$ & & & & & \\
\hline 1994 & 3445 & 394833075440101 & New Garden & 300WSCKO & LU & & & & & & \\
\hline 1994 & 3482 & 395115075441101 & East Marlborough & 400FLCGH & LU & $\mathrm{x}$ & & & & & \\
\hline 1994 & 3484 & 395054075450601 & New Garden & 400FLCGH & LU & $\mathrm{x}$ & & & & & \\
\hline 1994 & 4801 & 401228075353201 & East Coventry & 231BRCK & DU & $\mathrm{x}$ & & & & & \\
\hline 1994 & 4802 & 400055075421801 & Caln & 377KZRS & IPT & $\mathrm{x}$ & & & & & \\
\hline 1994 & 4803 & 401017075352901 & East Vincent & 231BRCK & DU & $\mathrm{x}$ & & & & & \\
\hline 1994 & 4804 & 400327075314801 & East Whiteland & 377LDGR & DU & $\mathrm{x}$ & & & & & \\
\hline 1994 & 4805 & 400241075332101 & East Whiteland & 371ELBK & IPT & & & & & & \\
\hline 1994 & 4806 & 394750075582901 & Lower Oxford & 300WSCKO & LU & $\mathrm{x}$ & & & $\mathrm{m}$ & & \\
\hline 1994 & 4807 & 394812075442901 & New Garden & 300WSCKO & IPT & & & & & & \\
\hline 1994 & 4808 & 394758075450401 & New Garden & 000MFCGH & IPT & $\mathrm{x}$ & $\mathrm{m}$ & & $\mathrm{m}$ & & \\
\hline 1994 & 4809 & 395044075435601 & New Garden & 300STRS & LU & & & & & & \\
\hline 1994 & 5087 & 400202075504001 & West Caln & 400BMFGA & LU & & & & & & \\
\hline 1994 & 5088 & 400152075512701 & West Caln & 400BMFGA & LU & $\mathrm{x}$ & & & & & \\
\hline
\end{tabular}


Appendix 1. List of wells and streams sampled by year and summary of water-quality-sampling results for the Chester County groundwater-quality monitoring program, 1980-2008.-Continued

\begin{tabular}{|c|c|c|c|c|c|c|c|c|c|c|c|}
\hline $\begin{array}{c}\text { Year } \\
\text { sampled }\end{array}$ & $\begin{array}{c}\text { Local } \\
\text { well } \\
\text { number }\end{array}$ & Station number & Township/Stream & Gunit & $\begin{array}{l}\text { Reason } \\
\text { sampled }\end{array}$ & $\begin{array}{c}\text { Man- } \\
\text { made } \\
\text { organic } \\
\text { com- } \\
\text { pound }\end{array}$ & VOC & \multicolumn{4}{|c|}{ MCL or HA exceeded } \\
\hline 1995 & 30 & 395046075415001 & Kennett & 300STRS & $\mathrm{LU}$ & $\mathrm{x}$ & & & $\mathrm{m}$ & & \\
\hline 1995 & 2461 & 394940075525901 & Penn & 300WSCKO & LU & $\mathrm{x}$ & & $\mathrm{m}$ & $\mathrm{m}$ & & \\
\hline 1995 & 3859 & 400214075334301 & East Whiteland & $367 \mathrm{CNSG}$ & IPT & $\mathrm{x}$ & $\mathrm{m}$ & & & & \\
\hline 1995 & 4133 & 394858075482301 & London Grove & 300WSCKO & LU & $\mathrm{x}$ & & & $\mathrm{m}$ & & \\
\hline 1995 & 4339 & 400238075465901 & East Brandywine & 400FCIGA & LU & $\mathrm{x}$ & & & & & \\
\hline 1995 & 4539 & 400229075465601 & East Brandywine & 400FCIGA & LU & $\mathrm{x}$ & & & & & \\
\hline 1995 & 4767 & 400123075544401 & West Caln & 377АМНР & DU & & & & & & \\
\hline 1995 & 4768 & 400918075303201 & Schuylkill & 231LCKG & DU & & & & & & \\
\hline 1995 & 4772 & 400045075381301 & West Whiteland & 300WSCKA & DU & & & & & & \\
\hline 1995 & 4778 & 400016075473201 & Caln & 400FCIGA & IPT & $\mathrm{x}$ & & & & & \\
\hline 1995 & 4779 & 395902075513801 & Valley & 400FMFG & DU & & & & & & \\
\hline 1995 & 5220 & 395709075441601 & West Bradford & 300PRCK & IPT & $\mathrm{x}$ & & & & $\mathrm{m}$ & \\
\hline 1995 & 5221 & 395105075412101 & Kennett & 400FLCGH & LU & & & & $\mathrm{m}$ & $\mathrm{m}$ & \\
\hline 1995 & 5222 & 395017075442701 & New Garden & $300 \mathrm{CCKV}$ & LU & $\mathrm{x}$ & & & $\mathrm{m}$ & & \\
\hline 1995 & 5223 & 394918075450801 & New Garden & 300WSCKO & NA & $\mathrm{x}$ & & & $\mathrm{m}$ & & \\
\hline 1995 & 5225 & 394427076022101 & Nottingham & 000SRPN & LU & & & & & & \\
\hline 1995 & 5226 & 394347076031101 & Nottingham & 000SRPN & LU & & & & & & \\
\hline 1995 & 5227 & 395924075405601 & East Bradford & 300WSCKA & DU & $\mathrm{x}$ & & & & $\mathrm{m}$ & \\
\hline 1995 & 5228 & 395345075413201 & Pocopson & 300WSCKO & LU & & & & & & \\
\hline 1995 & 5238 & 400227075463701 & East Brandywine & 400FCIGA & LU & $\mathrm{x}$ & & & & & \\
\hline 1995 & 5259 & 395610075334301 & Westtown & 400FLCGH & LU & $\mathrm{x}$ & & & & & \\
\hline 1995 & 5260 & 395612075334701 & Westtown & 400FLCGH & LU & & & & & & \\
\hline 1995 & 5261 & 395614075335701 & Westtown & 400FLCGH & LU & & & & & & \\
\hline 1995 & 5269 & 400911075364601 & East Vincent & $231 \mathrm{SCKN}$ & LU & $\mathrm{x}$ & & & & & \\
\hline 1995 & 5270 & 400922075364701 & East Vincent & $231 \mathrm{SCKN}$ & LU & $\mathrm{x}$ & & & & & \\
\hline 1995 & 5272 & 400918075365801 & East Vincent & $231 \mathrm{SCKN}$ & LU & $\mathrm{x}$ & & & & & \\
\hline
\end{tabular}


Appendix 1. List of wells and streams sampled by year and summary of water-quality-sampling results for the Chester County groundwater-quality monitoring program, 1980-2008.-Continued

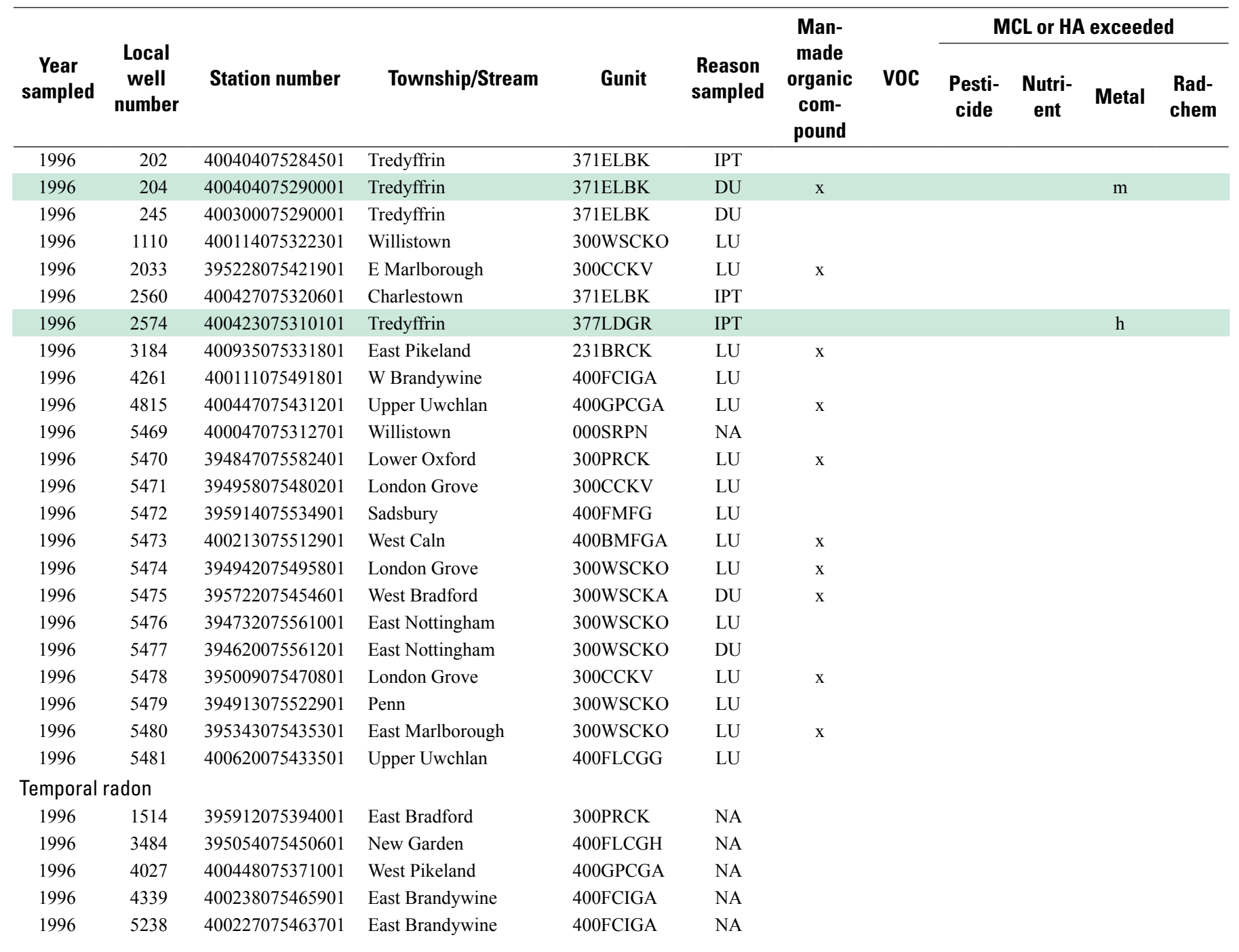




\section{Groundwater-Quality Monitoring Program in Chester County, Pennsylvania, 1980-2008}

Appendix 1. List of wells and streams sampled by year and summary of water-quality-sampling results for the Chester County groundwater-quality monitoring program, 1980-2008.-Continued

\begin{tabular}{|c|c|c|c|c|c|c|c|c|c|c|c|}
\hline $\begin{array}{c}\text { Year } \\
\text { sampled }\end{array}$ & $\begin{array}{c}\text { Local } \\
\text { well } \\
\text { number }\end{array}$ & Station number & Township/Stream & Gunit & $\begin{array}{l}\text { Reason } \\
\text { sampled }\end{array}$ & $\begin{array}{c}\text { Man- } \\
\text { made } \\
\text { organic } \\
\text { com- } \\
\text { pound }\end{array}$ & VOC & \multicolumn{4}{|c|}{ MCL or HA exceeded } \\
\hline 1997 & 432 & 395202075402001 & East Marlborough & 400FLCGH & LU & $\mathrm{x}$ & & & & & \\
\hline 1997 & 1281 & 400538075533001 & Honey Brook & 400FLCGG & LU & & & & & & \\
\hline 1997 & 5554 & 400639075555801 & Honey Brook & 400FLCGG & DU & & & & & $\mathrm{m}$ & \\
\hline 1997 & 5555 & 394942075461201 & New Garden & 300CCKV & LU & $\mathrm{x}$ & & & & & \\
\hline 1997 & 5556 & 400944075371301 & East Vincent & $231 \mathrm{SCKN}$ & LU & & & & & & \\
\hline 1997 & 5557 & 400338075483601 & West Brandywine & 377CCKS & LU & $\mathrm{x}$ & & & & & \\
\hline 1997 & 5558 & 395924075425001 & West Bradford & 300WSCKA & LU & & & & & $\mathrm{m}$ & \\
\hline 1997 & 5563 & 395917075424201 & West Bradford & 300WSCKA & LU & $\mathrm{x}$ & & & & & \\
\hline \multicolumn{12}{|c|}{ Temporal radon } \\
\hline 1997 & 1514 & 395912075394001 & East Bradford & 300PRCK & NA & & & & & & \\
\hline 1997 & 3484 & 395054075450601 & New Garden & 400FLCGH & NA & & & & & & \\
\hline 1997 & 4027 & 400448075371001 & West Pikeland & 400GPCGA & NA & & & & & & \\
\hline 1997 & 4339 & 400238075465901 & East Brandywine & 400FCIGA & NA & & & & & & \\
\hline 1997 & 5238 & 400227075463701 & East Brandywine & 400FCIGA & NA & & & & & & \\
\hline
\end{tabular}


Appendix 1. List of wells and streams sampled by year and summary of water-quality-sampling results for the Chester County groundwater-quality monitoring program, 1980-2008.-Continued

\begin{tabular}{|c|c|c|c|c|c|c|c|c|c|c|c|}
\hline $\begin{array}{c}\text { Year } \\
\text { sampled }\end{array}$ & $\begin{array}{c}\text { Local } \\
\text { well } \\
\text { number }\end{array}$ & Station number & Township/Stream & Gunit & $\begin{array}{l}\text { Reason } \\
\text { sampled }\end{array}$ & $\begin{array}{c}\text { Man- } \\
\text { made } \\
\text { organic } \\
\text { com- } \\
\text { pound }\end{array}$ & VOC & \multicolumn{4}{|c|}{ MCL or HA exceeded } \\
\hline 1998 & 2311 & 395331075544101 & Highland & 300PRCK & $\mathrm{LU}$ & $\mathrm{x}$ & & & $\mathrm{m}$ & & \\
\hline 1998 & 4817 & 400543075435501 & Upper Uwchlan & 400FLCGG & LU & & & & & & \\
\hline 1998 & 5243 & 400215075405001 & Uwchlan & 377CCKS & DU & $\mathrm{x}$ & & & & & \\
\hline 1998 & 5244 & 400216075405101 & Uwchlan & 377CCKS & DU & $\mathrm{x}$ & & & & & \\
\hline 1998 & 5559 & 395314075422301 & East Marlborough & 300WSCKO & IPT & & & & & & \\
\hline
\end{tabular}




\section{Groundwater-Quality Monitoring Program in Chester County, Pennsylvania, 1980-2008}

Appendix 1. List of wells and streams sampled by year and summary of water-quality-sampling results for the Chester County groundwater-quality monitoring program, 1980-2008.-Continued

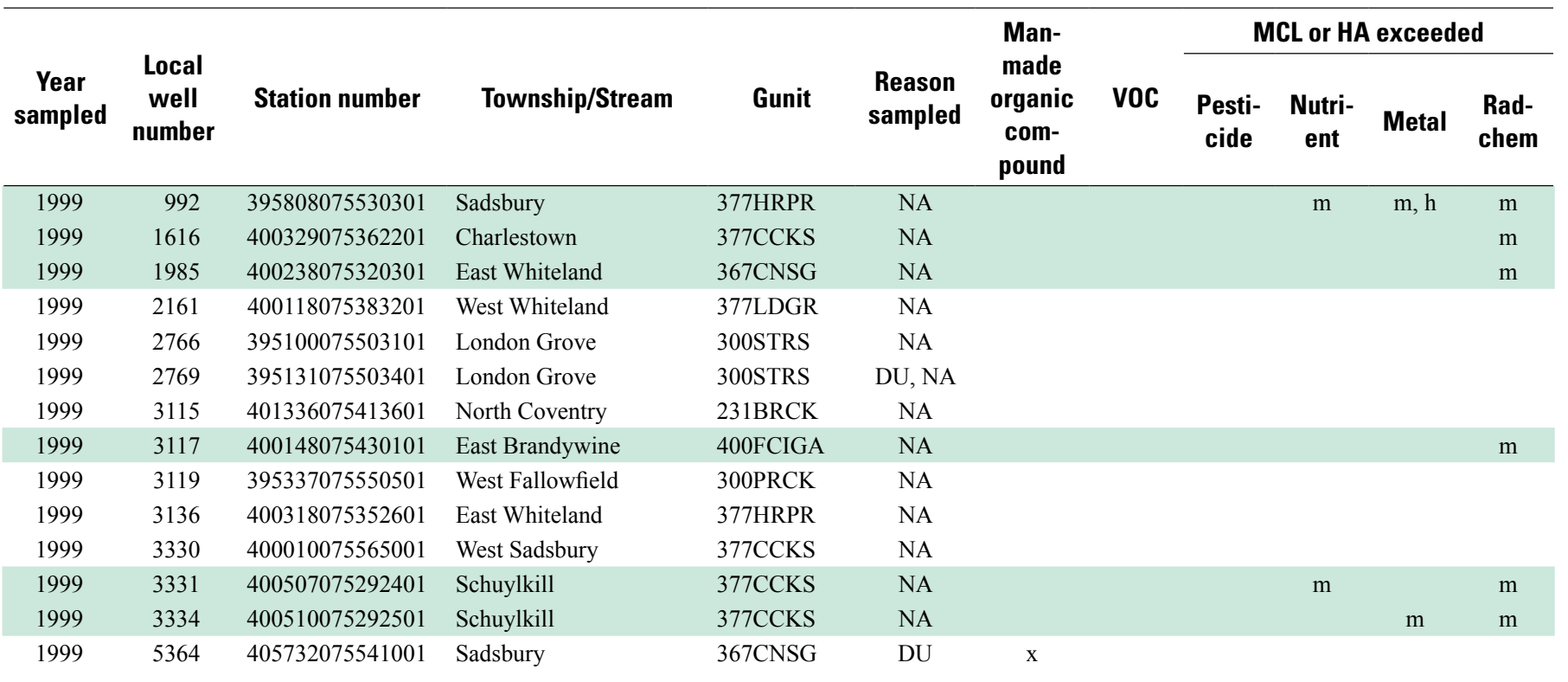


Appendix 1. List of wells and streams sampled by year and summary of water-quality-sampling results for the Chester County groundwater-quality monitoring program, 1980-2008.-Continued

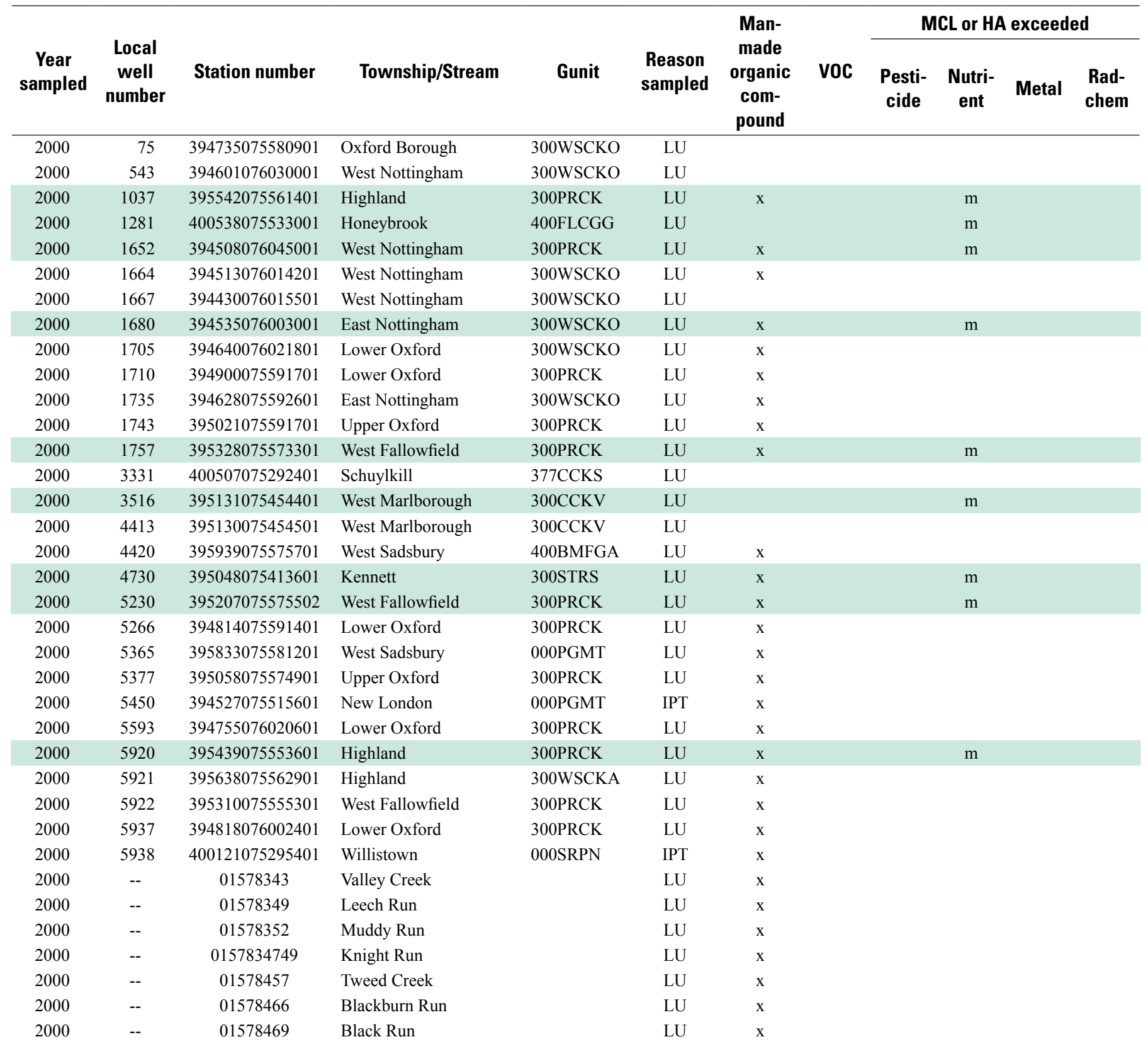


Appendix 1. List of wells and streams sampled by year and summary of water-quality-sampling results for the Chester County groundwater-quality monitoring program, 1980-2008.-Continued

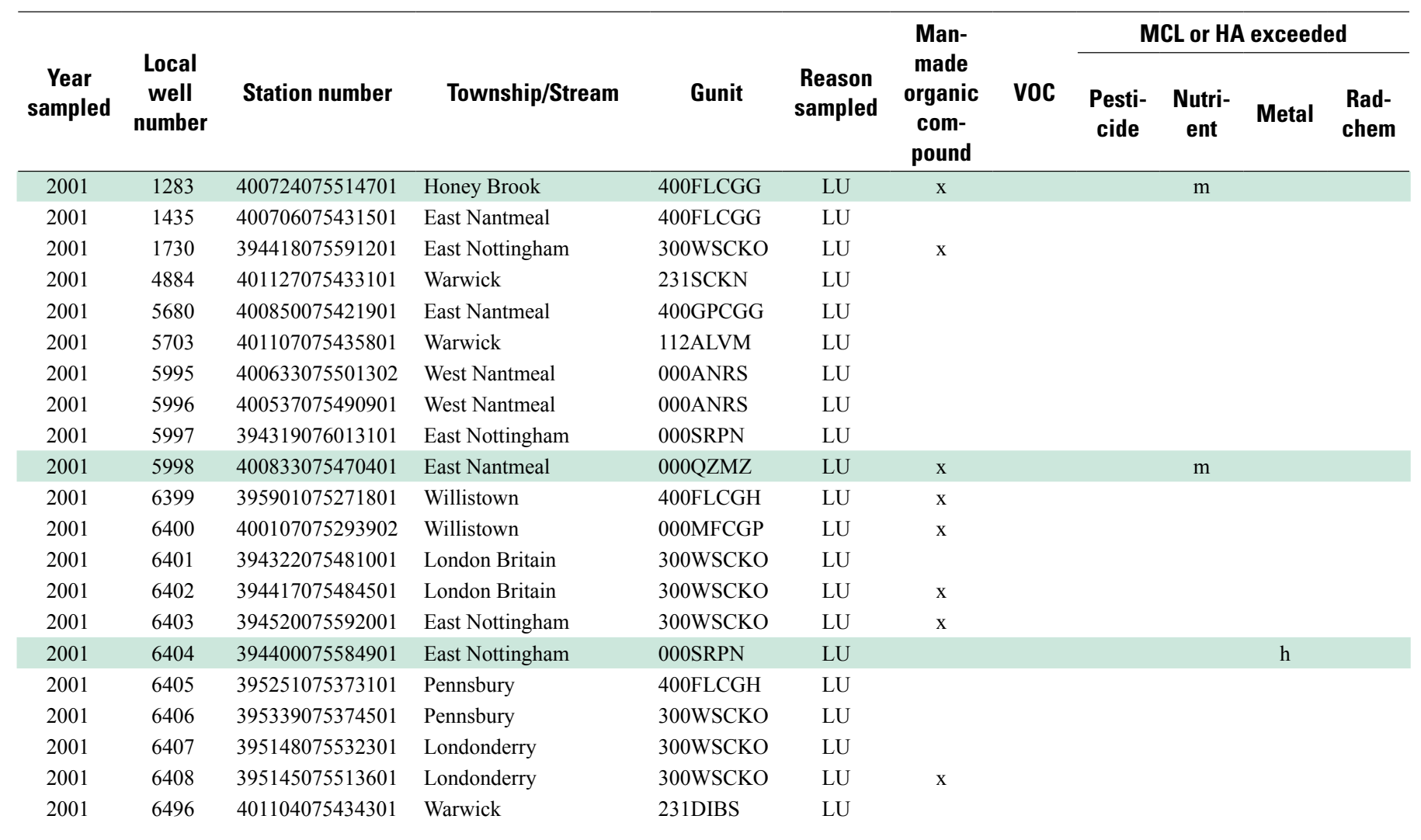


Appendix 1. List of wells and streams sampled by year and summary of water-quality-sampling results for the Chester County groundwater-quality monitoring program, 1980-2008.-Continued

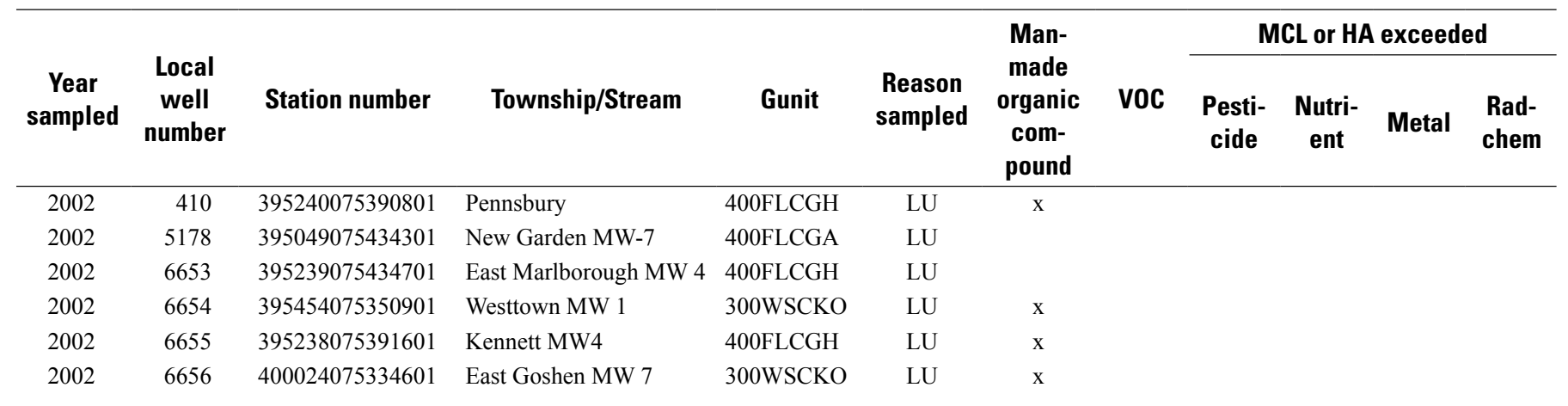


Appendix 1. List of wells and streams sampled by year and summary of water-quality-sampling results for the Chester County groundwater-quality monitoring program, 1980-2008.-Continued

\begin{tabular}{|c|c|c|c|c|c|c|c|c|c|c|c|}
\hline $\begin{array}{c}\text { Year } \\
\text { sampled }\end{array}$ & $\begin{array}{c}\text { Local } \\
\text { well } \\
\text { number }\end{array}$ & Station number & Township/Stream & Gunit & $\begin{array}{l}\text { Reason } \\
\text { sampled }\end{array}$ & $\begin{array}{c}\text { Man- } \\
\text { made } \\
\text { organic } \\
\text { com- } \\
\text { pound }\end{array}$ & VOC & \multicolumn{4}{|c|}{ MCL or HA exceeded } \\
\hline 2003 & 86 & 400227075430801 & East Brandywine & 377CCKS & NA & & & & & & $\mathrm{m}$ \\
\hline 2003 & 992 & 395808075530301 & Sadsbury & 377HRPR & NA & & & & $\mathrm{m}$ & $\mathrm{h}$ & \\
\hline 2003 & 3125 & 400224075432701 & East Brandywine & 377CCKS & NA & & & & & & $\mathrm{m}$ \\
\hline 2003 & 3327 & 400212075541101 & West Caln & 377CCKS & NA & & & & & & $\mathrm{m}$ \\
\hline 2003 & 3995 & 400543075281001 & Schuylkill & 377CCKS & NA & & & & & & \\
\hline 2003 & 4771 & 400122075543201 & West Caln & 377CCKS & NA & & & & & $\mathrm{m}$ & \\
\hline 2003 & 6514 & 400126075551001 & West Caln & 377АMHP & NA & & & & & & \\
\hline 2003 & 6644 & 400505075292401 & Tredyffrin & 377CCKS & NA & & & & & & $\mathrm{m}$ \\
\hline 2003 & 6646 & 395957075543601 & West Caln & $377 \mathrm{CCKS}$ & NA & & & & & & $\mathrm{m}$ \\
\hline 2003 & 6647 & 395951075543001 & West Caln & 377CCKS & NA & & & & & & \\
\hline 2003 & 6824 & 400247075545901 & West Caln & 377CCKS & NA & & & & & & $\mathrm{m}$ \\
\hline
\end{tabular}


Appendix 1. List of wells and streams sampled by year and summary of water-quality-sampling results for the Chester County groundwater-quality monitoring program, 1980-2008.-Continued

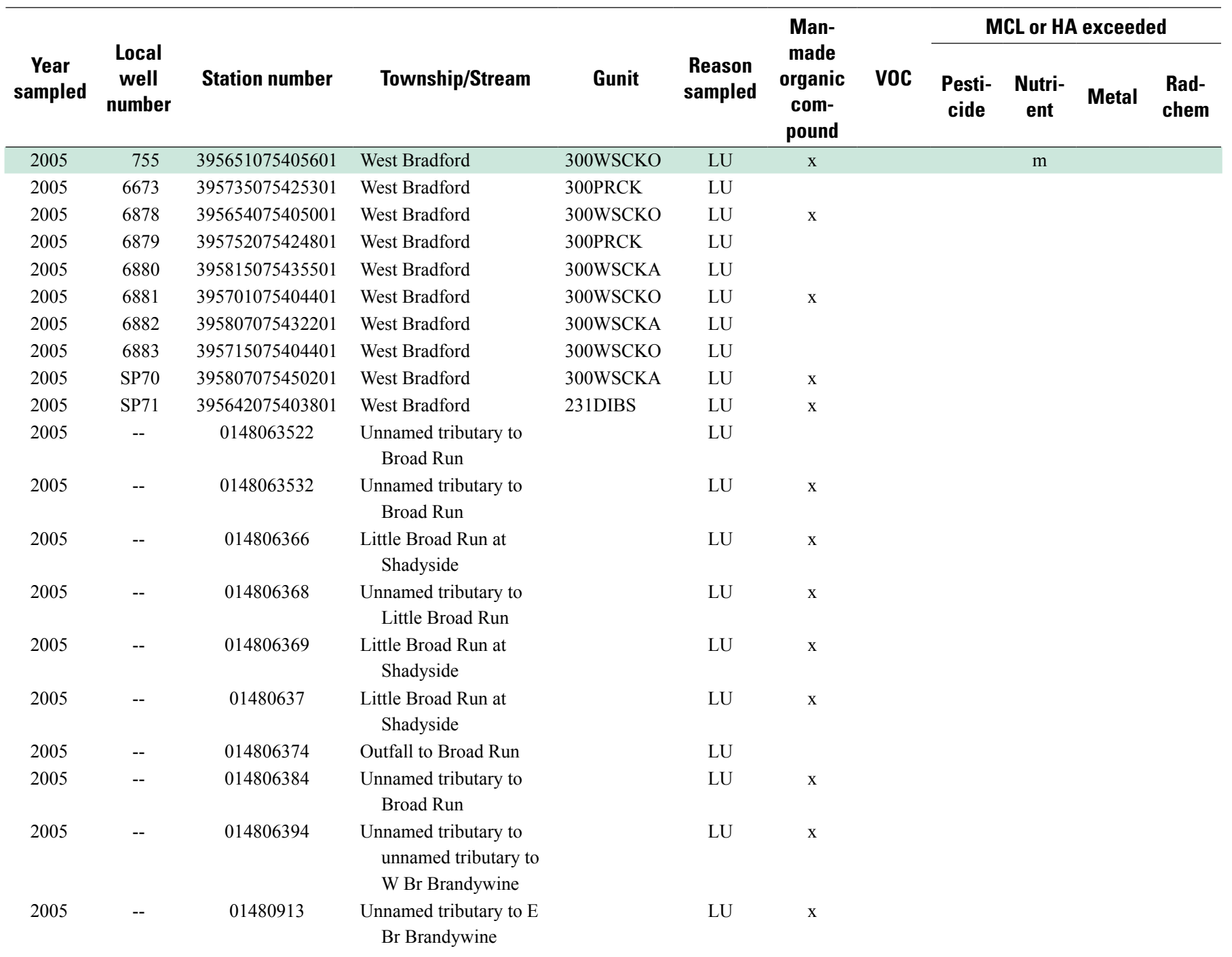


Appendix 1. List of wells and streams sampled by year and summary of water-quality-sampling results for the Chester County groundwater-quality monitoring program, 1980-2008.-Continued

\begin{tabular}{|c|c|c|c|c|c|c|c|c|c|c|c|}
\hline \multirow[b]{2}{*}{$\begin{array}{c}\text { Year } \\
\text { sampled }\end{array}$} & \multirow[b]{2}{*}{$\begin{array}{c}\text { Local } \\
\text { well } \\
\text { number }\end{array}$} & \multirow[b]{2}{*}{ Station number } & \multirow[b]{2}{*}{ Township/Stream } & \multirow[b]{2}{*}{ Gunit } & \multirow[b]{2}{*}{$\begin{array}{l}\text { Reason } \\
\text { sampled }\end{array}$} & \multirow{2}{*}{$\begin{array}{c}\text { Man- } \\
\text { made } \\
\text { organic } \\
\text { com- } \\
\text { pound }\end{array}$} & \multirow[b]{2}{*}{ VOC } & \multicolumn{4}{|c|}{ MCL or HA exceeded } \\
\hline & & & & & & & & $\begin{array}{c}\text { Pesti- } \\
\text { cide }\end{array}$ & $\begin{array}{c}\text { Nutri- } \\
\text { ent }\end{array}$ & Metal & $\begin{array}{l}\text { Rad- } \\
\text { chem }\end{array}$ \\
\hline 2006 & 83 & 395346075421001 & East Marlborough & 300WSCKO & NA & & & & & & \\
\hline 2006 & 1483 & 401020075433501 & Warwick & 231SCKN & NA & & & & & & \\
\hline 2006 & 1613 & 400536075381501 & West Pikeland & 400GPCGA & NA & & & & & & \\
\hline 2006 & 1801 & 394417075471501 & London Britain & 000MFCGH & NA & & & & & & \\
\hline 2006 & 1978 & 400231075334701 & East Whiteland & 371ELBK & NA & & & & & & \\
\hline 2006 & 1985 & 400238075320301 & East Whiteland & 367CNSG & NA & & & & & & $\mathrm{m}$ \\
\hline 2006 & 2021 & 394933075403801 & Kennett & 300WSCKO & NA & & & & & & \\
\hline 2006 & 2189 & 394646075592501 & Oxford Borough & 300WSCKO & NA & & & & & & \\
\hline 2006 & 2421 & 395322075561701 & West Fallowfield & 300PRCK & NA & & & & & & \\
\hline 2006 & 2433 & 400620075563801 & Honey Brook & 377CCKS & NA & & & & $\mathrm{m}$ & & \\
\hline 2006 & 2725 & 400058075384801 & East Caln & 371ELBK & NA & & & & & & \\
\hline 2006 & 2766 & 395100075503101 & London Grove & 300STRS & NA & & & & & & \\
\hline 2006 & 3077 & 400601075501401 & West Nantmeal & 000ANRS & NA & & & & & & \\
\hline 2006 & 3117 & 400148075430101 & East Brandywine & 400FCIGA & NA & & & & & & \\
\hline 2006 & 3300 & 400622075310502 & Schuylkill & 400FCIGA & NA & & & & & & \\
\hline 2006 & 3302 & 395623075454902 & Newlin & 300PRCK & NA & & & & & & \\
\hline 2006 & 3334 & 400510075292501 & Schuylkill & 377CCKS & NA & & & & & & $\mathrm{m}$ \\
\hline 2006 & 3365 & 400237075540601 & West Caln & 377CCKS & NA & & & & & $\mathrm{m}$ & $\mathrm{m}$ \\
\hline 2006 & 3918 & 395947075391301 & East Bradford & 300WSCKA & NA & & & & & & \\
\hline 2006 & 4155 & 400207075441301 & East Brandywine & 400FCIGA & NA & & & & & & \\
\hline 2006 & 4195 & 400258075412801 & Uwchlan & 400FCIGA & NA & & & & & & \\
\hline 2006 & 4294 & 394857075504201 & London Grove & 300WSCKO & NA & & & & & & \\
\hline 2006 & 4505 & 400211075475901 & West Brandywine & 400FLCGA & $\mathrm{DU}$ & & & & $\mathrm{m}$ & & \\
\hline 2006 & 4817 & 400543075435501 & Upper Uwchlan & 400FLCGG & NA & & & & & & \\
\hline 2006 & 5221 & 395105075412101 & Kennett & 400FLCGH & NA & & & & $\mathrm{m}$ & & \\
\hline 2006 & 5457 & 395142075533501 & Londonderry & 300WSCKO & NA & & & & & & \\
\hline 2006 & 6538 & 395311075552401 & West Fallowfield & 300PRCK & NA & & & & $\mathrm{m}$ & & \\
\hline 2006 & 7266 & 400353075283401 & Tredyffrin & 371ELBK & NA & & & & & & \\
\hline 2006 & 7267 & 400712075332601 & East Pikeland & 231SCKN & NA & & & & & & \\
\hline 2006 & 7268 & 400026075380601 & West Whiteland & 300WSCKA & NA & & & & & & \\
\hline
\end{tabular}


Appendix 1. List of wells and streams sampled by year and summary of water-quality-sampling results for the Chester County groundwater-quality monitoring program, 1980-2008.-Continued

\begin{tabular}{|c|c|c|c|c|c|c|c|c|c|c|c|}
\hline $\begin{array}{c}\text { Year } \\
\text { sampled }\end{array}$ & $\begin{array}{c}\text { Local } \\
\text { well } \\
\text { number }\end{array}$ & Station number & Township/Stream & Gunit & $\begin{array}{l}\text { Reason } \\
\text { sampled }\end{array}$ & $\begin{array}{c}\text { Man- } \\
\text { made } \\
\text { organic } \\
\text { com- } \\
\text { pound }\end{array}$ & VOC & \multicolumn{4}{|c|}{ MCL or HA exceeded } \\
\hline 2007 & 7220 & 400151075463101 & East Brandywine & 400FCIGA & $\mathrm{LU}$ & & & & & & \\
\hline 2007 & 7236 & 400147075462501 & East Brandywine & 400BMFGA & LU & $\mathrm{x}$ & & & & & \\
\hline 2007 & -- & 014806215 & Buck Run & & LU & $\mathrm{x}$ & & & & & \\
\hline 2007 & -- & 0148063528 & Broad Run & & $\mathrm{LU}$ & $\mathrm{x}$ & & & & & \\
\hline 2007 & -- & 01480656 & Indian Run & & $\mathrm{LU}$ & $\mathrm{x}$ & & & & & \\
\hline 2007 & -- & 01480662 & Culbertson Run & & LU & $\mathrm{x}$ & & & & & \\
\hline 2007 & -- & 01480739 & Beaver Creek & & LU & $\mathrm{x}$ & & & $\mathrm{m}$ & & \\
\hline 2007 & -- & 01480744 & Beaver Creek reservoir & & LU & $\mathrm{x}$ & & & & & \\
\hline 2007 & -- & 014807447 & $\begin{array}{l}\text { Beaver Creek reservoir } \\
\text { outfall }\end{array}$ & & LU & $\mathrm{x}$ & & & & & \\
\hline 2007 & -- & 01480745 & Beaver Creek & & LU & $\mathrm{x}$ & & & & & \\
\hline 2007 & -- & 01480750 & Beaver Creek & & LU & $\mathrm{x}$ & & & & & \\
\hline
\end{tabular}


Appendix 1. List of wells and streams sampled by year and summary of water-quality-sampling results for the Chester County groundwater-quality monitoring program, 1980-2008.-Continued

\begin{tabular}{|c|c|c|c|c|c|c|c|c|c|c|c|}
\hline $\begin{array}{c}\text { Year } \\
\text { sampled }\end{array}$ & $\begin{array}{c}\text { Local } \\
\text { well } \\
\text { number }\end{array}$ & Station number & Township/Stream & Gunit & $\begin{array}{l}\text { Reason } \\
\text { sampled }\end{array}$ & $\begin{array}{c}\text { Man- } \\
\text { made } \\
\text { organic } \\
\text { com- } \\
\text { pound }\end{array}$ & VOC & \multicolumn{4}{|c|}{ MCL or HA exceeded } \\
\hline 2008 & 4230 & 400045075490201 & & & LU & & & & & & \\
\hline 2008 & 4261 & 400111075491801 & & & LU & $\mathrm{x}$ & & & & & \\
\hline 2008 & 5444 & 400556075420301 & & & LU & $\mathrm{x}$ & & & & & \\
\hline 2008 & -- & 01480160 & $\begin{array}{c}\text { Unnamed trib to } \mathrm{W} \mathrm{Br} \text {. } \\
\text { Brandywine Creek }\end{array}$ & & LU & $\mathrm{x}$ & & & & & \\
\hline 2008 & -- & 01480457 & Rock Run & & LU & $\mathrm{x}$ & & & & & \\
\hline 2008 & -- & 014806775 & Black Horse Creek & & LU & $\mathrm{x}$ & & & & & \\
\hline
\end{tabular}



Prepared by the West Trenton Publishing Service Center.

For more information concerning this report, contact:

Director

U.S. Geological Survey

Pennsylvania Water Science Center

215 Limekiln Road

New Cumberland, PA 17070

dc_pa@usgs.gov

or visit our Web site at:

http://pa.water.usgs.gov 
